RICARDO ALEXANDRE VEIGA GIMENES

MÉTODO DE AVALIAÇÃO DE SEGURANÇA CRÍTICA PARA A INTEGRAÇÃO DE VEÍCULOS AÉREOS NẪO TRIPULADOS NO ESPAÇO AÉREO CONTROLADO E NÃO SEGREGADO 
RICARDO ALEXANDRE VEIGA GIMENES

\title{
MÉTODO DE AVALIAÇÃO DE SEGURANCA CRÍTICA PARA A INTEGRAÇÃO DE VEÍCULOS AÉREOS NẪO TRIPULADOS NO ESPAÇO AÉREO CONTROLADO E NÃO SEGREGADO
}

\author{
Tese apresentada à Escola \\ Politécnica da Universidade de São \\ Paulo para a obtenção do Título de \\ Doutor em Ciências
}

Área de Concentração: Engenharia de Computação

Orientador: Professor Livre-Docente Jorge Rady de Almeida Júnior 
Assinatura do autor:

Assinatura do orientador:

Catalogação-na-publicação

Gimenes, Ricardo Alexandre Veiga

Método de Avaliação de Segurança Crítica para a Integração de

Veículos Aéreos Não Tripulados no Espaço Aéreo Controlado e Não

Segregado / R. A.

V. Gimenes -- versão corr. -- São Paulo, 2015.

$159 \mathrm{p}$.

Tese (Doutorado) - Escola Politécnica da Universidade de São Paulo. Departamento de Engenharia de Computação e Sistemas Digitais.

1.Aeronáutica 2.VANT 3.Segurança 4.Automação 5.Tráfego Aéreo I.Universidade de São Paulo. Escola Politécnica. Departamento de Engenharia de Computação e Sistemas Digitais II.t. 
Dedico este trabalho à minha filha Laura, por trazer um novo significado à minha vida! 


\section{AGRADECIMENTOS}

À minha esposa Patrícia, que, com muita paciência, sempre me apoiou e transmitiu força de vontade e motivação, mesmo nos momentos mais difíceis.

Aos Meus pais Luiz e Vera e ao meu irmão André que forneceram total apoio, incentivo e estrutura física e mental para a realização deste trabalho.

Ao Prof. Dr. Jorge Rady de Almeida Jr. que, sendo um excelente orientador e amigo, permitiu o desenvolvimento das minhas ideias, muitas vezes ambiciosas e maiores do que poderiam ser realizadas, sempre transmitindo total confiança em meu potencial ao mesmo tempo em que me mantinha focado com a realidade.

Ao Prof. Dr. João Batista Camargo Jr. pelo apoio à minha pesquisa e por oferecer um ambiente para desenvolver novas ideias.

Aos amigos pesquisadores Lúcio Vismari e Marcelo Lopes pela participação construtiva nas diversas discussões e debates sobre os mais variados temas que contribuíram sobremaneira para elaboração desta Tese.

Aos colegas do Grupo de Análise de Segurança - GAS da Escola Politécnica da Universidade de São Paulo, que, com muita responsabilidade, desenvolvem pesquisas de Análise de Segurança para que todos possam ter uma vida melhor. 
Cindindo a vastidão do Azul profundo,

Sulcando o espaço, devassando a terra,

A Aeronave que um mistério encerra

Vai pelo espaço acompanhando o mundo.

E na esteira sem fim da azúlea esfera

Ei-la embalada n'amplidão dos ares,

Fitando o abismo sepulcral dos mares

Vencendo o azul que ante si s'erguera.

Voa, se eleva em busca do Infinito, É como um despertar de estranho mito,

Auroreando a humana consciência.

Cheia da luz do cintilar de um astro,

Deixa ver na fulgência do seu rastro A trajetória augusta da Ciência.

Augusto dos Anjos 


\section{RESUMO}

A crescente demanda por Veículos Aéreos Não Tripulados (VANT) tem sido objeto de preocupação por parte das organizações internacionais responsáveis pela segurança do espaço aéreo. O uso de VANT em condições restritas tem sido realizado pelos interessados e envolvidos, mas para que o VANT seja economicamente viável, há a necessidade de regulamentação ainda não existente para sua integração segura no Espaço Aéreo Controlado e Não Segregado. Em função dessa demanda não atendida, nesta Tese foi desenvolvido um método (Safety-VANT) que avalia a segurança crítica da condução do VANT, tarefa realizada por um Sistema Autônomo de Pilotagem. O desenvolvimento do Método Safety-VANT tem como missão fornecer aos órgãos reguladores, assim como aos desenvolvedores de VANT, meios de quantificar a avaliação de segurança na navegabilidade aérea dessas aeronaves. Uma hipótese considerada para o método é a de que o hardware e software (aviônicos, fuselagem, sensores e atuadores) do VANT estejam previamente avaliados e certificados pelos mesmos procedimentos e regras aplicáveis para os equipamentos de aeronaves tripuladas. Essa hipótese permitiu que o desenvolvimento do método de avaliação de segurança SafetyVANT fosse direcionado para avaliar a capacidade de comando autônomo de um VANT para voar, navegar e comunicar de acordo com as regras do sistema de gerenciamento e controle do tráfego aéreo. A aplicação do Safety-VANT foi exercitada sob um VANT hipotético definido como sendo capaz de voar, navegar e se comunicar com o Controle de Tráfego Aéreo e que tenha os equipamentos e estrutura da aeronave (fuselagem) que 0 constitui, devidamente certificados. Adicionalmente são realizadas considerações sobre como implantar a utilização do Safety-VANT no desenvolvimento de VANT Autônomo com a missão de ser integrado no Espaço Aéreo.

Palavras-chave: VANT, Segurança Crítica, Espaço Aéreo, Sistema Autônomo, Sistema Embarcado. 


\begin{abstract}
The growing demand for unmanned aerial vehicles (UAV) has been a subject of concern on the part of international organizations responsible for airspace safety. UAV has been used by stakeholders in strict conditions, but for UAV to become economically viable, it is necessary to issue regulations that still do not exist for safe integration in the controlled non-segregated airspace. In the light of this unattended demand, a method (Safety-VANT) was developed in this Thesis to evaluate the critical safety of UAV conduction, a task performed by a Piloting Autonomous System. The development of the Safety-VANT method aims to provide UAV regulators and developers, means of quantifying the safety assessment in the aircraft airworthiness. A hypothesis used in the method considers that the UAV hardware and software (avionics, fairing, sensors and actuators) are previously evaluated and certified by the same procedures and rules applicable to manned aircraft equipment. This hypothesis allowed the Safety-VANT - the developed safety assessment method - to evaluate the ability of an autonomous command embedded in an UAV to fly, to navigate and to communicate, according to the management of air navigation system rules. The Safety-VANT application was exercised under a hypothetical UAV set to being able to fly, to navigate and to communicate with Air Traffic Control and it has the equipment and the certified aircraft structure (fairing). In addition, considerations are performed for deploying the use of Safety-VANT in autonomous UAV development to integrate it into the Airspace.
\end{abstract}

Keywords: UAS, Safety, Airspace, Autonomous System, Embedded System. 


\section{LISTA DE ILUSTRAÇÕES}

FIGURA 1.1 - MODELO PARA O DESENVOLVIMENTO DE UM MÉTODO ......................................................2 21

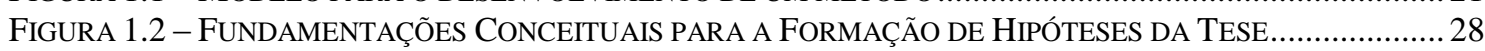

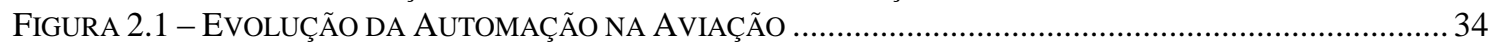

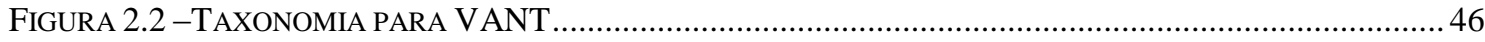

FIGURA 2.3 - PERSPECTIVA DO ATC NA PRESENÇA DE VANT E AERONAVES TRIPULADAS .......................47

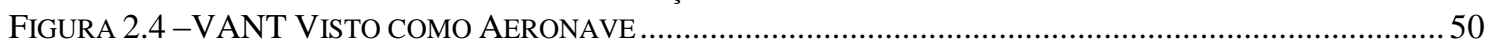

FIGURA 3.1 - RELACIONAMENTO ENTRE O PROCESSO DE CERTIFICAÇÃo DE SEGURANÇA CRÍTICA E O CICLO

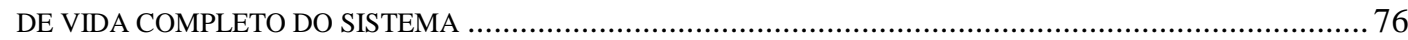

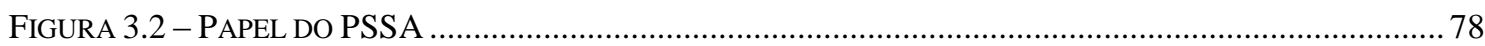

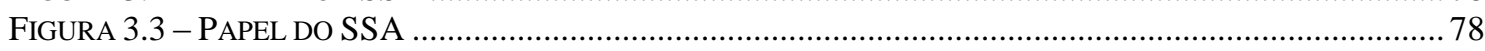

FIGURA 3.4 - ALGORITMO DA ESCALA COOPER HARPER .................................................................... 81

FIGURA 4.1 - ALTERAÇÕES NECESSÁRIAS DA EUROCONTROL SAM PARA VANT …................................93

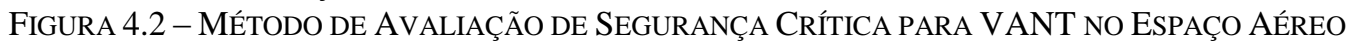

CONTROLADO E NÃO SEGREGADO: SAFETY-VANT ................................................................... 97

FIGURA 4.3 - IMPORTÂNCIA DO ESPECIALISTA NO MÉTODO SAFETY-VANT .........................................99

FIGURA 4.4 - DESENVOLVIMENTO DOS REQUISITOS GERAIS DE SEGURANÇA ...................................... 102

FIGURA 4.5 - ALGORITMO DA ESCALA COOPER HARPER MODIFICADA ............................................... 125

FIGURA 4.6 - COMANDO DA AERONAVE SUJEITO AO TESTE DE TURING ................................................ 128

FIGURA 4.7 - PROCESSO DO AVALIADOR ESPECIALISTA PARA APLICAR O SAFETY-VANT ..................... 130 


\section{LISTA DE TABELAS}

TABela 4.1 - MAPEAmento DE Requisitos Gerais de SEguranÇA PARA TESTE DE CONHECIMENTO. 112 TABELA 4.2 - MAPEAMENTO DE REQUiSITOS GERAIS DE SEGURANÇA PARA TREINAMENTO DE VoO .......115 TABELA 4.3 - MAPEAMENTO DE REQUISITOS GERAIS DE SEGURANÇA PARA EXPERIÊNCIA DE VoO ........ 117 TABELA 4.4 - MAPEAMENTO DE REQUISITOS GERAIS DE SEGURANÇA PARA INTEGRAÇÃo COM O ATM GLOBAL

TABELA 4.5 - AVALIAÇÃO DE UM SAP BASEADO NOS CRITÉRIOS DE HABILITAÇÃO PARA PILOTOS HUMANOS: TESTE DE CONHECIMENTO DO SAP

TABELA 4.6 - AVALIAÇÃO DE UM SAP BASEADO NOS CRITÉRIOS DE HABILITAÇÃO PARA PILOTOS HUMANOS: TREINAMENTO DE VOO DO SAP

TABELA 4.7 - AVALIAÇÃO DE UM SAP BASEADO NOS CRITÉRIOS DE HABILITAÇÃO PARA PILOTOS HUMANOS: EXPERIÊNCIA DE VOO DO SAP

TABELA 4.8 - AVALIAÇÃO DE UM SAP BASEADO NOS CRITÉRIOS DE HABILITAÇÃO PARA PILOTOS HUMANOS: PONTO DE VISTA DO ATM GLOBAL DO SAP. 


\section{LISTA DE ABREVIATURAS E SIGLAS}

AIP - Publicação de Informação Aeronáutica (Aeronautical Information Publication);

ANAC - Agência Nacional de Aviação Civil;

ANS - Sistema de Navegação Aérea (Air Navigation System);

AWY - Aerovias;

ATC - Controle de Tráfego Aéreo (Air Traffic Control);

ATM - Gerenciamento de Tráfego Aéreo (Air Traffic Manangement);

CAVE - Certificado de Autorização de Voo Experimental;

CTR - Zonas de Controle;

EASA - Agência de Segurança da Aviação Europeia (European Aviation Safety Agency);

Eurocontrol - European Organization for the Safety of Air Navigation;

ESARR - Eurocontrol Safety Regulatory Requirements;

FAA - Autoridade Federal de Aviação dos EUA (Federal Aviation Authority);

FAR - Federal Aviation Regulations;

FHA - Functional Hazard Analysis

FMEA - Failure Model and Effect Analysis

FTA - Fault Tree Analysis;

GAIN - Global Aviation Safety Network;

JAA - Joint Aviation Authorities;

JAR - Joint Airworthiness Requirements;

NLR - Nationaal Lucht- en Ruimtevaartlaboratorium;

NOTAM - Aviso que contém informação relativa ao estabelecimento, condição ou modificação de quaisquer instalações, serviços, procedimentos ou perigos 
aeronáuticos, cujo pronto conhecimento seja indispensável ao pessoal ligado à operações de voo (DECEA, 2015)

NSA - Autoridade Nacional de Fiscalização (National Supervisory Authority);

OACI - Organização da Aviação Civil Internacional (ICAO - International Civil Aviation Organization);

PSSA - Avaliação Preliminar de Seguranaça do Sistema (Preliminary System Safety Assessment);

RGS - Requisito Geral de Segurança;

RES - Requisito Específico de Segurança;

RPA - Aeronave Remotamente Pilotada (Remotely-Piloted Aircraft);

RPAS - Sistema de Aeronave Remotamente Pilotada (Remotely-Piloted Aircraft System);

SAM - Metodologia de Avaliação de Segurança (Safety Assessment Methodology);

SAP - Sistema Autônomo de Pilotagem;

SARPS - Práticas Recomendadas e Padrões (Standards and Recommended Practices);

SRC - Comissão de Regulação de Segurança (Safety Regulation Commission);

SSA - Avaliação de Segurança de Sistema (System Safety Assessment);

TMA - Áreas de Controle;

VANT - Veículo Aéreo Não Tripulado (Unmanned Aerial Vehicle);

SISVANT - Sistema de Navegação para Veículo Aéreo Não Tripulado. 


\section{SUMÁRIO}

1. INTRODUÇÃO

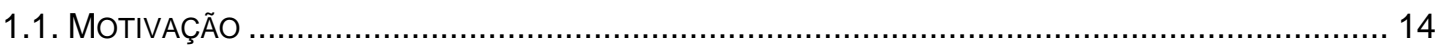

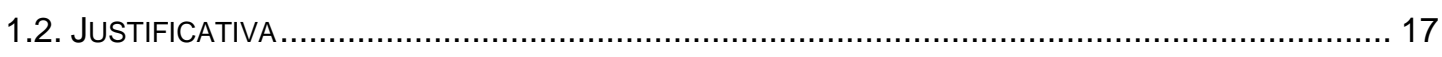

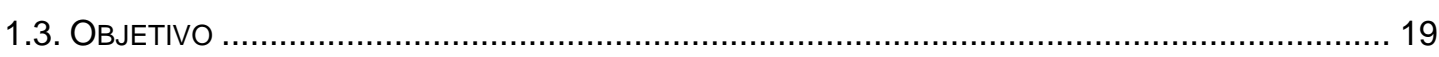

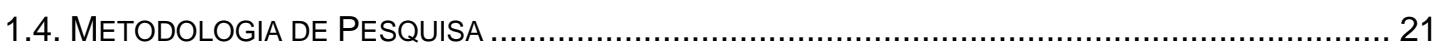

1.4.1. Disponibilização do Método e da Avaliação de Segurança Apresentada ............... 25

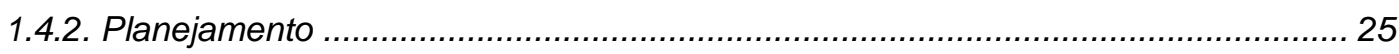

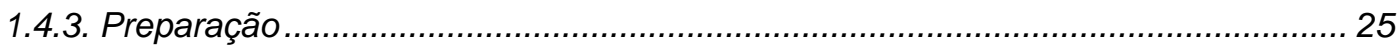

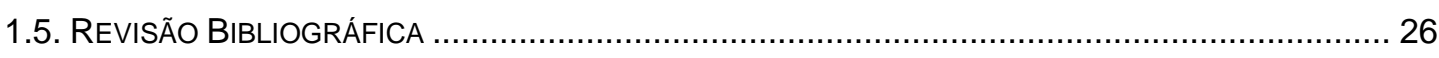

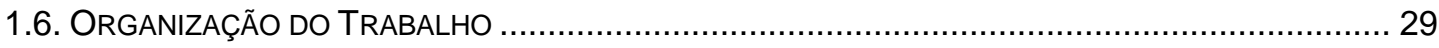

2. VEÍCULOS AÉREOS NÃO TRIPULADOS ................................................................ 31

2.1. A EvoluÇÃo da AutomaÇÃo em Sistemas CRíTICOS na AviaÇÃo .................................... 32

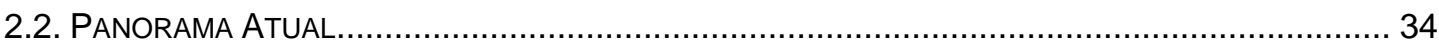

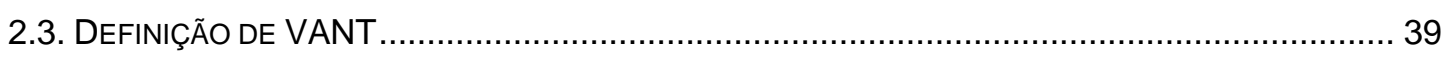

2.3.1. Definição de VANT pelas Autoridades Governamentais ...................................... 39

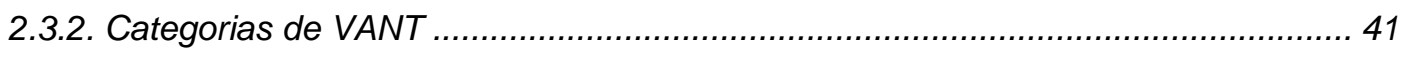

2.3.3. VANT como Aeronave Controlada por Sistema Autônomo de Pilotagem ................ 42

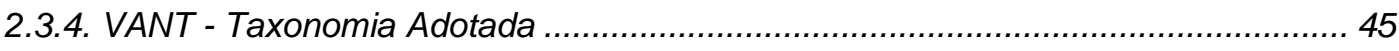

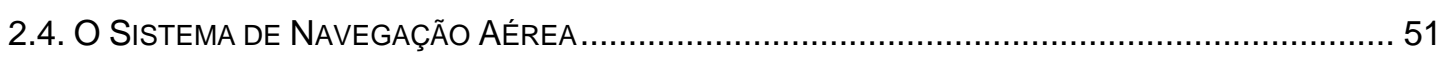

2.4.1. Concepção Operacional ATM Global da OACI (ICAO Global ATM Operational

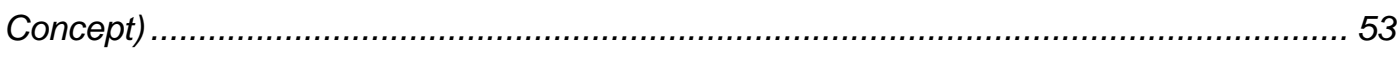

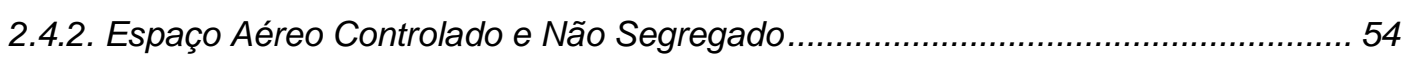

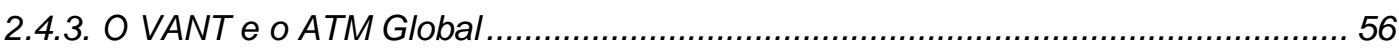

3. MÉTOdOS DE AVALIAÇÃO DE SEGURANÇA CRÍTICA APLICADAS À AVIAÇÃO ... 58

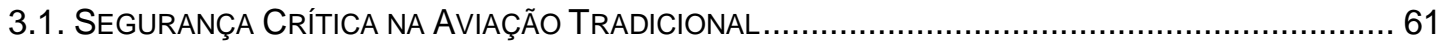

3.2. OS DESAFIOS DO VANT PERANTE AS ORGANIZAÇÕES AERONÁUTICAS .................................62

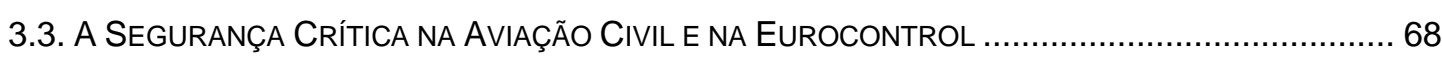

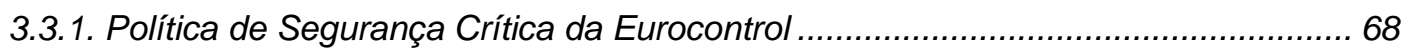

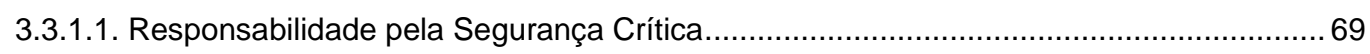

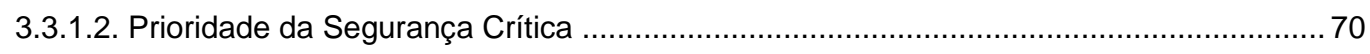

3.3.1.3. Objetivo de Segurança Crítica dos Serviços de Navegação Aérea................................ 70

3.3.2. Requisitos Regulatórios de Segurança da Eurocontrol ...................................... 70

3.4. Metodologia de Avaliação de Segurança (Safety Assessment Methodology- E-

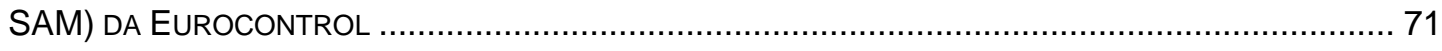

3.4.1. O Processo Functional Hazard Assessment (FHA) ........................................... 76

3.4.2. O Processo Preliminary System Safety Assessment (PSSA) ............................. 77 
3.4.3. O Processo System Safety Assessment (SSA) ................................................. 78

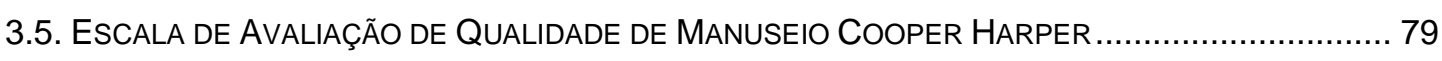

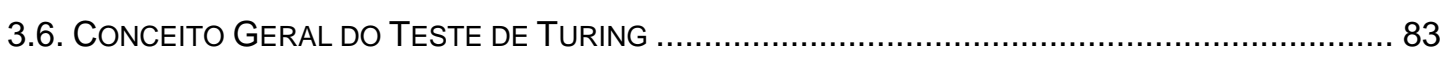

\section{SAFETY-VANT: MÉTODO DE AVALIAÇÃO DE SEGURANÇA CRÍTICA PARA A INTEGRAÇÃO DE VANT NO ESPAÇO AÉREO CONTROLADO E NÃO SEGREGADO . 85}

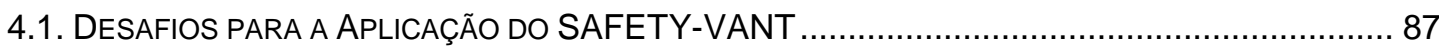

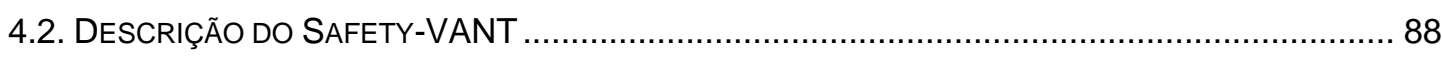

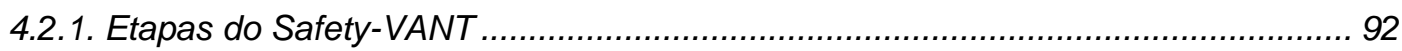

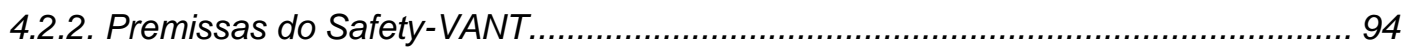

4.3. METODOLOGIA EUROCONTROL SAM APLICADA AO SAFETY-VANT ..................................... 99

4.3.1. Desenvolvimento dos Requisitos Gerais de Segurança por meio da Metodologia

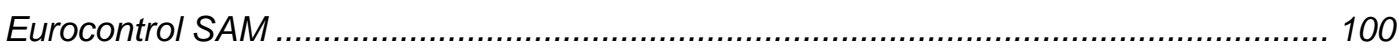

4.3.2. Requisitos Gerais de Segurança do Ponto de Vista da Aeronave ....................... 106

4.3.3. Requisitos Gerais de Segurança do Ponto de Vista do Licenciamento do Piloto

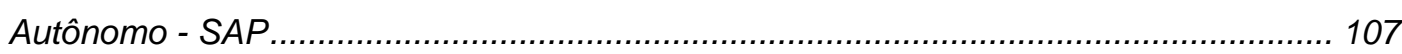

4.3.3.1. Requisitos Gerais de Segurança para Teste de Conhecimento .................................... 108

4.3.3.2. Requisitos Gerais de Segurança para Treinamento de Voo ........................................113

4.3.3.3. Requisitos Gerais de Segurança para Experiência de Voo ........................................ 116

4.3.4. Requisitos Gerais de Segurança do Ponto de Vista do ATM Global..................... 117

4.4. ESCALA COOPER HARPER MODIFICADA PARA O SAFETY-VANT .................................. 118

4.4.1. Importância do Avaliador Especialista no Uso da Escala Cooper Harper Modificada

4.4.2. Modificação da Escala Cooper Harper para Safety-VANT ............................... 121

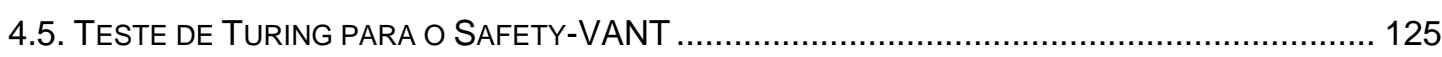

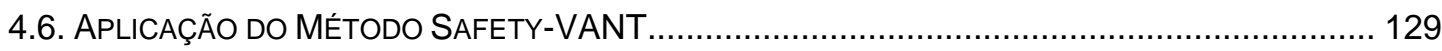

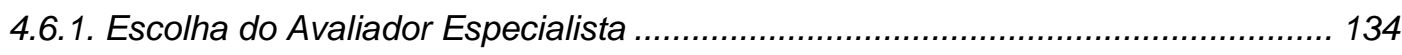

4.6.2. Uso dos Requisitos Gerais de Segurança pelos Especialistas ........................... 134

4.6.3. Exemplo de Aplicação para o Safety-VANT ................................................... 134

5. CONCLUSÕES

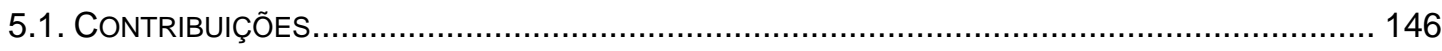

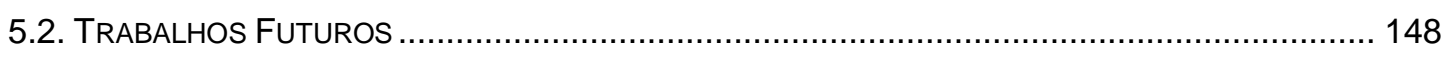

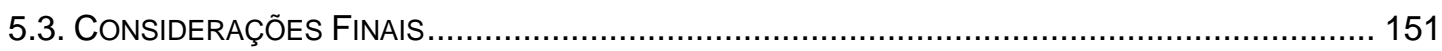




\section{INTRODUÇÃO}

O desenvolvimento de Veículos Aéreos Não Tripulados (VANT ${ }^{1}$ ) para uso civil, se comparado à aviação civil tradicional, ainda está em sua fase inicial (STRONG, 2008; GIMENES, 2014). No campo científico relacionado ao VANT, é necessário entender que o desenvolvimento tecnológico é apenas parte do problema a ser resolvido. Soluções envolvendo sistemas de inteligência artificial, entre outras áreas do conhecimento, têm sido pesquisadas com o objetivo de desenvolver métodos de tomada de decisão capazes de evitar colisões entre aeronaves (inclusive tripuladas) no espaço aéreo em situações em que o ser humano não é capaz de reagir em tempo suficiente. Mesmo com a tecnologia à disposição da ciência, quando há a necessidade de se utilizar uma aeronave não tripulada em um espaço aéreo compartilhado com outras aeronaves tripuladas, surgem novas questões de cunho jurídico e social (GIMENES; ALMEIDA, 2011), dependendo assim de estudos científicos para a ponderação dessa integração.

\subsection{Motivação}

Tendo em vista a demanda atual e futura pelo emprego de VANT em aplicações civis, é dever da comunidade avaliar os meios que possibilitem a regulamentação de VANT, com a visão de garantir a sua utilização segura, uma vez que tais soluções tendem a depender de algum grau de automação que implicam em substituir o controle humano da aeronave por sistemas autônomos. Uma motivação para tal afirmação é o grau de automação já atingido em aeronaves comerciais de grande porte. Tais tecnologias permitem o voo automático em cruzeiro, assim como, em condições especiais, sua decolagem e pouso são feitas, obrigatoriamente, em modo automático, como é - caso do pouso completamente automático denominado por CAT IIlc (SCHIFF, 2003, p. 205). Do ponto de vista de tecnologia e conceitos de voo, um avião comercial tal como as aeronaves Boeing 787 e Airbus A380 podem ser consideradas como uma classe de VANT, uma vez que seu controle de

\footnotetext{
${ }^{1}$ Nesta Tese é utilizado o acrônimo VANT para designar tanto uma única aeronave, quanto diversas aeronaves não tripuladas.
} 
voo, pouso e decolagem são feitos com significativo grau de automação (AUSTIN, 2010).

Consequentemente, é importante ressaltar que o VANT é, antes de se considerar a automação, uma aeronave. Esse fator é muitas vezes subjugado por equipes de desenvolvimento de VANT, entretanto essa informação simplifica o entendimento das condições necessárias e suficientes para a sua operação.

Mas, apesar de o VANT ser obrigado a seguir as regras que os órgãos reguladores da aviação civil definem, assim como qualquer aeronave que deseja voar no espaço aéreo compartilhado, ainda há um campo da ciência pouco explorado em pesquisas e artigos científicos: aspectos de segurança crítica para a integração desse tipo de aeronave no espaço aéreo mundial. Segurança Crítica é definida por Almeida (2003) como a probabilidade, em um período de tempo, de que um sistema não atinja um estado considerado inseguro ou perigoso. Um estado inseguro é definido como sendo parte de um subconjunto dos estados de falha de um sistema. Neste contexto, há um cenário de incerteza tanto no Brasil quanto no exterior, pois a pressão empresarial para se ter o uso de VANT para uso comercial tem demandado uma força tarefa internacional na qual o Brasil tem participado ativamente.

A hipótese principal de toda pesquisa envolvendo certificação de VANT é a de que a sua integração no espaço aéreo deve atender aos mesmos níveis de segurança crítica já existentes na aviação civil. Além disso, o VANT a ser utilizado deve atender aos requisitos mínimos necessários e suficientes para operar, de forma segura no espaço aéreo. A viabilização do uso de VANT no espaço aéreo, então, necessita de uma quantificação de fatores que envolvem Tecnologia, Regras de Utilização do Espaço Aéreo, Procedimentos Operacionais (tanto em voo como em solo) e dos requisitos não funcionais de disponibilidade, confiabilidade e segurança crítica.

Assim, pode-se observar que há quase 70 anos já existia a preocupação sobre regulamentação de veículos autônomos. Consequentemente, a evolução da tecnologia tem aberto novas frentes de pensamento sobre o assunto tal como foi apresentado por Nicholas A. Sabatini, 2006, Administrador da Segurança da 
Aviação da FAA (Federal Aviation Adminstration - Estados Unidos) que afirmou: "The development and use of unmanned aircraft is the next great step forward in the evolution of aviation" (SABATINI, 2006). Este tipo de afirmação demonstra que veículos aéreos não tripulados merecem uma forte atenção no meio aeronáutico, assim como na comunidade científica.

A solução das organizações internacionais tem sido a de limitar o escopo sobre a integração do VANT no espaço aéreo controlado em função de suas características físicas, mas essa solução deixaria a análise limitada às características físicas da aeronave, tais como tamanho e peso. Ainda não há uma definição da Lista Mínima de Equipamentos (Minimum Equipment List MEL) para as categorias de VANT, tal como um avião civil que possua todos os equipamentos necessários para voar em um espaço aéreo controlado, seja segregado ou não.

Considerando a futura integração do VANT no espaço aéreo, a adaptação deve considerar as regras e definições já existentes da $\mathrm{OACl}$, tendo como uma importante contribuição, a descrição de atividades específicas a serem validadas pelo método.

Modelos de VANT, mesmo quando remotamente controlados, possuem programação de manobra de retorno automático em caso de perda do controle remoto. A complexidade envolvida nessa manobra de retorno automático para a base envolve questões especiais, pois o VANT passa a ser completamente autônomo em tal cenário. Dessa forma, há uma quantidade significativa de questionamentos a serem feitos: o VANT está longe da base? Ele tem sensores de altitude ou o voo estaria sendo realizado visualmente? $E$ se houver outras aeronaves na região que ele precisa cruzar na rota de retorno? Ele saberá desviar? A autonomia dele permite chegar à base? Se não permite, ele consegue rastrear, de forma autônoma, a melhor área de pouso? A seguradora está ciente dos riscos relacionados ao plano de voo aprovado pelo DECEA? Se ocorrer um acidente de um VANT, ele seria obrigado a ter uma caixa preta? Mas se o acidente ocorreu quando o enlace de comunicação de dados foi rompido com o piloto remoto, de quem é a responsabilidade civil caso existam vítimas em solo? 
Esse tipo de questionamento requer muita discussão tanto na tecnologia envolvida quanto nos aspectos normativos a serem adotados neste novo panorama. A demanda reprimida por ofertas de voo dessa natureza, gerada pelas empresas envolvidas, estimula que os órgãos responsáveis acelerem o processo legal e social, realimentando, assim, o desenvolvimento tecnológico com o objetivo de permitir um maior número de aeronaves não tripuladas no espaço aéreo controlado e segregado. É importante ter em mente que as normas e procedimentos da aviação civil atual foram gerados a partir de um vasto histórico de acidentes e incidentes. Essa fonte de informação não é mais uma opção para a realidade do VANT. Isso implica que a integração de VANT no espaço aéreo não segregado deve respeitar e atender as taxas máximas de acidentes aéreos aceitos na aviação civil tripulada.

\subsection{Justificativa}

Independente da falta de regulamentação para seu uso civil, o espaço aéreo vem sendo gradualmente exposto aos veículos aéreos não tripulados, tais como se observam imagens de emissoras de televisão se utilizando dessa tecnologia (WHITLOCK, 2014). Apesar de se conhecer tais usos, é importante ressaltar que todos eles não possuem aprovação da ANAC (ANAC, 2011b) e do DECEA (DECEA, 2011).

A aviação civil mundial tem evoluído para atender à crescente demanda sem que se comprometa a segurança de todo o sistema aeronáutico. Neste novo ambiente de desenvolvimento industrial, surgiu uma nova demanda comercial no setor aeronáutico: a necessidade de desenvolver métodos de avaliação da segurança crítica para aplicações comerciais e civis de VANT.

Durante a revisão bibliográfica, observou-se uma quantidade tecnicamente inferior de pesquisas relacionadas aos desafios que os VANT geram quando se deseja integrá-los no Espaço Aéreo compartilhado com as demais aeronaves tripuladas e também quando se deseja sobrevoar VANT em áreas urbanas em relação às pesquisas de desenvolvimento de VANT.

Acredita-se que veículos de grande porte para transporte de carga e inclusive de passageiros poderão ser uma realidade em poucas décadas, conceito que 
vem sendo reforçado ao longo dos anos em pesquisas como Dossier (1999) e Gupta; Ghonge e Jawandhiya (2013).

Apesar de haver muitas aplicações de VANT no universo militar, as aplicações civis são ainda muito restritas e não possuem regulamentação específica necessária para sua utilização de maneira efetiva (EUROCONTROL, 2012). Pesquisas e construções de VANT (civil e militar) têm mostrado que existe tecnologia suficiente para VANT voarem em ambientes hoje ocupados pela aviação civil tradicional. Porém o enlace de comunicação de dados que garante que os VANT possam ser aplicados à aviação civil tradicional ainda é uma área pouco explorada e com muitas dúvidas, tanto por parte da sociedade quanto da comunidade científica.

A demanda por métodos de certificação de novas tecnologias como as empregadas nos VANT incentiva o desenvolvimento, pela comunidade científica, de métodos para a avaliação de sua segurança crítica. Em parceria com os órgãos reguladores, a comunidade científica deve apresentar métodos de avaliação que poderão ser utilizados por esses órgãos reguladores.

No entanto, os órgãos responsáveis pela liberação da circulação de VANT no espaço aéreo controlado e não segregado ainda não possuem elementos suficientes que assegurem a não exposição da sociedade a riscos maiores do que os existentes no cenário atual, ou seja, sem os VANT. A ANAC, DECEA e demais órgãos certificadores internacionais não dispõem de métodos de certificação de VANT aceitos como válidos.

Tendo em vista a demanda atual e futura pelo emprego de VANT em aplicações civis, pesquisas científicas, tais como esta Tese, procuram apresentar meios que possam ser utilizados pelos órgãos reguladores de forma a possibilitar a confecção de uma regulamentação de VANT no espaço aéreo brasileiro, respeitando as normas de segurança necessárias.

Desta forma, torna-se necessário o desenvolvimento de um método que possibilite a verificação por parte dos órgãos responsáveis se um VANT apresentado por um fabricante está apto a voar de forma segura no espaço aéreo. Estar apto significa que o VANT vá se submeter aos procedimentos e regras já existentes. O projeto e construção estão em franco desenvolvimento, 
mas não possuem, no momento, regras definidas de como podem ou poderão ser utilizados. Em contrapartida, os equipamentos de navegação minimamente necessários para que as aeronaves possam navegar em espaço aéreo controlado e não segregado ainda apresentam um custo muito alto (tanto financeiro quanto em carga útil), inviabilizando seu uso nessas condições. Vale ainda ressaltar que tais equipamentos "mínimos", embora necessários, não são suficientes, uma vez que eles não operam a aeronave, apenas fornecem informações de voo, navegação e comunicação ao comandante da aeronave.

A integração do VANT tem-se tornado um grande desafio para 0 gerenciamento do espaço aéreo, o que torna necessário o desenvolvimento de novos métodos de avaliação de segurança crítica, visando que a integração de VANT no espaço aéreo seja realizada de maneira segura e confiável.

\subsection{Objetivo}

O objetivo desta Tese é definir um novo método de avaliação da segurança crítica para a introdução de Veículos Aéreos Não Tripulados em um espaço aéreo controlado e não segregado, espaço esse definido pela OACI, (ICAO, 2004) e sujeito às regras do Controle de Tráfego Aéreo. A principal contribuição desse novo método é permitir quantificar a habilidade de voar, navegar e comunicar de um VANT no espaço aéreo controlado e não segregado.

O método tem como hipótese que o software e o hardware do VANT em avaliação já tenham sido certificados pelos procedimentos e normas aplicáveis às aeronaves tripuladas e sistemas aviônicos. Dessa forma, o uso do método permite que o avaliador avalie a segurança de um determinado VANT sem ter de avaliar a tecnologia envolvida. Portanto, o método definido tem o objetivo de avaliar a segurança crítica do Sistema Autônomo de Pilotagem (SAP) que tem a missão de realizar as tarefas de Voar, Navegar e Comunicar o VANT integrado no espaço aéreo controlado e não segregado.

A base para o desenvolvimento do Método proposto é fundamentada no estudo de normas e metodologias de avaliação de segurança crítica (conhecidas como Safety Assessment Methodologies - SAM) utilizadas para a avaliação da segurança crítica na aviação civil internacional. Atualmente, estas metodologias 
são aplicadas às aeronaves tripuladas e controladas por seres humanos, simplificadamente denominadas nesta Tese como aeronaves tripuladas. Essas metodologias existentes têm seu foco nas condições necessárias e suficientes para que o voo de uma aeronave tripulada ocorra de maneira segura e confiável no espaço aéreo controlado em função de parâmetros pré-definidos de segurança. Deve-se entender por Voar, Navegar e Comunicar como a capacidade de um VANT atender às condições mínimas e necessárias em acordo com os requisitos de segurança da aviação mundial no espaço aéreo em que ele estiver inserido.

O método definido visa manter a coerência entre o panorama atual e o novo panorama representado pela integração dos VANT ao espaço aéreo ocupado por aeronaves tripuladas, ditas "convencionais". Tendo em vista essa lacuna na avaliação e certificação de VANT para a aviação civil, insere-se o desenvolvimento do método proposto nesta Tese, cuja base principal são as características já existentes da aviação civil, oferecendo caminhos para a certificação dos VANT, sem colocar a tecnologia envolvida como o foco da avaliação. A partir da definição do método de avaliação da segurança crítica para um VANT, pode-se avaliá-lo, por meio de sua submissão aos cenários de voo, de forma equivalente à aviação tradicional para a sua correta integração no Sistema de Navegação Aérea.

Um importante resultado esperado é a obtenção de um quantificador e, ao longo do uso desse quantificador, obter dados de comparação entre diferentes VANT que venham a ser testados sob os mesmos parâmetros.

Em função das restrições da aplicabilidade do método em um VANT físico, outro objetivo é desenvolver um exemplo de aplicação teórica sobre um VANT Autônomo hipotético. Essa aplicação deve utilizar os procedimentos e seus parâmetros correspondentes definidos no método proposto, considerando cenários que envolvam situações críticas de segurança.

O método desenvolvido nesta Tese visa proporcionar uma forma de se avaliar situações de perigo do ponto de vista de um órgão avaliador que observa uma aeronave e não uma tecnologia específica. Se a avaliação tivesse foco na tecnologia, isso limitaria o estudo, pois a avaliação seria relacionada às suas 
características físicas e não à sua capacidade de Voar, Navegar e se Comunicar. Portanto, esta Tese propõe uma visão de VANT como um avião civil que possua todos os equipamentos necessários para voar em um espaço aéreo controlado, com a condição inicial de esta aeronave não possuir controle humano a bordo.

\subsection{Metodologia de Pesquisa}

Uma metodologia fornece todos os recursos para abstrair a realidade observada, de forma sistemática com o intuito de dar as diretrizes para atingir os objetivos esperados. Segundo Yin (2010) cada diretriz direciona a atenção da pesquisa para determinados aspectos que devem ser examinados dentro do escopo de estudo. A metodologia oferece meios para que a realidade em análise seja abstraída, com o objetivo de orientar o caminho para atingir os objetivos de uma pesquisa. Uma metodologia apresenta a definição dos métodos e a forma de pesquisa que foi utilizada no desenvolvimento do trabalho. Segundo Oliveira (2012), método é uma forma de pensar para se chegar à natureza de um problema, quer seja para estudá-lo, quer seja para explicá-lo. O método utilizado para atingir o objetivo deste trabalho foi organizado segundo o esquema de Yin (2010) e está apresentado na Figura 1.1. Segundo Yin (2010) um projeto de pesquisa está relacionado à lógica que vincula os dados a serem coletados diretamente às questões iniciais do estudo. Para Yin, existe uma relação contínua entre as partes que devem ser consideradas durante todo o desenvolvimento da pesquisa, como ilustrado na Figura 1.1.

Figura 1.1 - Modelo para o desenvolvimento de um método

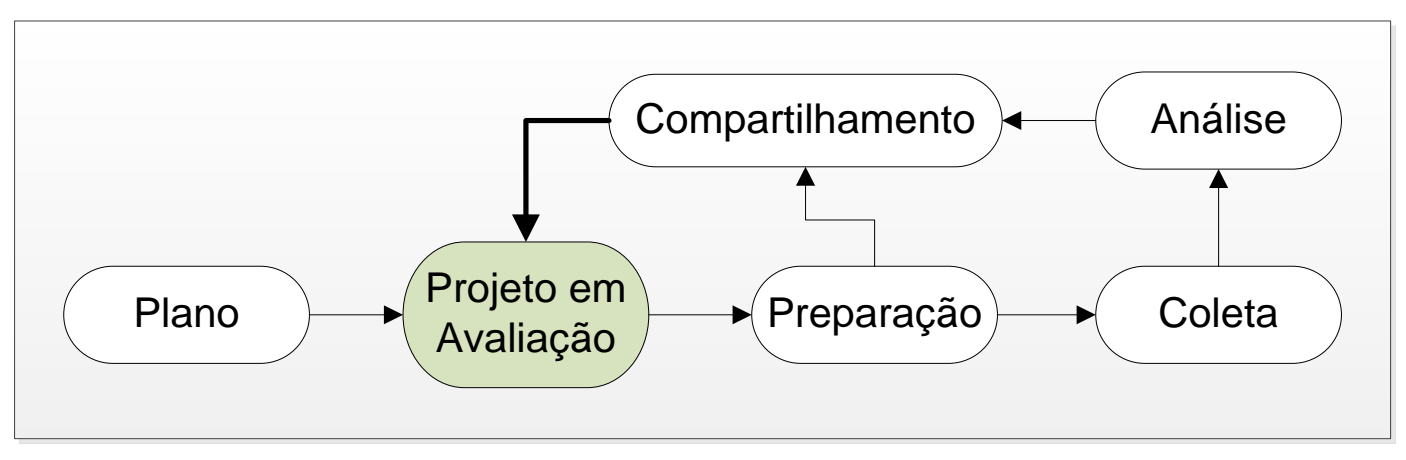

Fonte: Autor, Adaptado de Yin (2010) 
Yin define os elementos da Figura 1.1 como:

- Plano: identifica quais são as questões da pesquisa ou outras questões que justifiquem o estudo. Nessa fase é necessário decidir se o estudo de caso é o melhor método a ser aplicado, comparando-o a outros métodos de pesquisa.

- Projeto: O projeto orienta o pesquisador no processo de coleta, análise e interpretação das observações. Para estudos de caso, cinco componentes de um projeto de pesquisa são especialmente importantes:

1) As questões do estudo;

2) As proposições, se houver;

3) As unidades de análise (definir o que é o caso);

4) A lógica que une os dados às proposições; e

5) Os critérios para interpretar as constatações.

- Preparação: Nessa fase o pesquisador deve desenvolver habilidades para conduzir o estudo de caso, tais como:

1) Formular boas perguntas;

2) Interpretar as respostas;

3) Deve ser imparcial, para não ser atrapalhado por suas próprias ideologias ou preconceitos;

4) Ser adaptável e flexível para que situações novas possam ser aproveitadas como oportunidades e não serem vistas como ameaças; e

5) Deve ter noção clara sobre o assunto pesquisado.

- Coleta: A evidência do estudo de caso pode vir de várias fontes, tais como: documentação, registros em arquivos, entrevistas, observação direta, observação participante e artefatos físicos. Devem-se ter bons livros-texto de apoio, criar um banco de dados do estudo de caso e manter atualizado o encadeamento das evidências. 
- Análise: Para a análise utilizam-se técnicas para dados quantitativos, qualitativos ou ambos. Tabulação dos resultados, elaboração de séries temporais, categorização, testes ou simulações são usados para formular conclusões acerca do estudo realizado.

- Compartilhamento: Relatar um estudo de caso significa trazer seus resultados e constatações ao encerramento. Deve-se escolher um público alvo para apresentar as evidências. $O$ processo de compartilhamento das informações auxilia no processo de revisão para que se alcance um alto nível de apresentação e que outros pesquisadores tirem suas próprias conclusões a respeito do assunto.

Um método científico constitui-se no conjunto de processos ou operações mentais que se devem empregar na investigação. É a linha de raciocínio adotada no processo de pesquisa. De forma a construir o método seguindo uma metodologia científica, esta Tese se baseia no método dedutivo que fornece as bases lógicas à investigação (GIL, 1999; LAKATOS; MARCONI, 1993): "explicar o conteúdo das premissas por intermédio de uma cadeia de raciocínio em ordem descendente, de análise do geral para o particular, chega a uma conclusão (silogismo)". Na ausência de formas de validação analítica do método desenvolvido, utilizou-se a Pesquisa Explicativa do tipo ex-post-facto. (SILVA; MENEZES, 2005). Nesta última, as hipóteses são suposições colocadas como respostas plausíveis e provisórias para o problema de pesquisa, dada a ausência de um estudo de caso estatístico, pois Pesquisa Expost-Facto se define como quando o "experimento" se realiza depois dos fatos. Tem-se, então, as características ou critérios necessários para a validade das hipóteses (LAKATOS; MARCONI, 1993):

- Consistência lógica: o enunciado das hipóteses não pode ter contradições e deve ter compatibilidade com o corpo de conhecimentos científicos;

- Verificável: devem ser passíveis de verificação;

- Simplicidade: devem ser parcimoniosas evitando enunciados complexos;

- Relevância: devem ter poder preditivo e/ou explicativo; 
- Apoio teórico: devem ser baseadas em teoria para ter maior probabilidade de apresentar genuína contribuição ao conhecimento científico;

- Especificidade: devem indicar as operações e previsões a que elas devem ser expostas;

- Plausibilidade e clareza: devem propor algo admissível e que o enunciado possibilite o seu entendimento; e

- Profundidade, fertilidade e originalidade: devem especificar os mecanismos aos quais obedecem para alcançar níveis mais profundos da realidade, favorecer o maior número de deduções e expressar uma solução nova para o problema.

Para se realizar estudos de caso para o método desenvolvido nesta Tese, seria necessário estar de posse de um VANT que tivesse sido desenvolvido para ser integrado no espaço aéreo controlado e não segregado. Ainda não há VANT disponível com tais características, assim como não há autorização por parte das autoridades aeronáuticas que permita a realização de estudos de caso em campo para aplicar o método.

A validação de um método é um processo dinâmico e constante que começa nas fases de seleção, desenvolvimento e otimização do método e na qualificação dos instrumentos, materiais e pessoal e contínua da fase de experimentos e transferência do método. É importante ressaltar que a validação de um método envolve comparações com outros métodos atualmente usados. Um processo de validação bem definido e documentado fornece evidências objetivas de que o sistema e o método são adequados ao uso pretendido (SILVA; MENEZES, 2005).

A demanda por esse método, por parte das instituições reguladoras do espaço aéreo mundial mostrou ser válido o desenvolvimento do método definido nesta Tese, apesar de não se poder validá-lo com dados reais, no presente momento. Portanto, se embasando nos métodos de pesquisa apresentados, e contemplando uma aplicação teórica a título de exemplificação, esta Tese visou considerar as possibilidades de aplicabilidade do método. 


\subsubsection{Disponibilização do Método e da Avaliação de Segurança Apresentada}

Segundo Yin (2010), o compartilhamento das informações deve ser direcionado a um determinado público. Espera-se que esse público elabore conclusões a respeito do trabalho que possam contribuir com a sua respectiva pesquisa. No caso do esquema de Yin da Figura 1.1, ele não considera que, após o compartilhamento, seja possível retomar o fluxo das atividades. As publicações em congressos científicos na área relacionada a VANT e à Aviação Civil como um todo foram de muita importância para o crescimento do trabalho. Em particular, esta Tese destaca os estudos apresentados no Journal of Intelligent \& Robotic Systems (GIMENES, 2014) e no principal congresso de Veículos Aéreos Não Tripulados (GIMENES, 2013), recebendo retorno de fundamental importância para a validação dessa Tese.

\subsubsection{Planejamento}

Nesta etapa foi definido o problema a ser estudado: "VANT como Aeronave Autônoma a ser integrada no Espaço Aéreo Controlado e Não Segregado". A principal motivação para deste estudo foi a necessidade definir um método para realizar a avaliação de segurança desse VANT nesse contexto. $O$ estudo do tema central da Tese supracitado foi iniciado em busca de possíveis métodos que já realizassem tal avaliação.

\subsubsection{Preparação}

O estudo começa com uma revisão minuciosa da literatura e com a proposição cuidadosa que atenda às questões e objetivos da pesquisa. Igualmente importante é a dedicação aos procedimentos formais e explícitos ao realizar a pesquisa (YIN, 2010). Essa revisão de literatura, segundo Gil (1999) pode ser elaborada a partir de material já publicado, como livros, artigos, periódicos, Internet, entre outros. Para tanto, uma revisão bibliográfica foi feita desde o início da pesquisa desta Tese, apresentada na seção seguinte. 


\subsection{Revisão Bibliográfica}

O desenvolvimento de uma pesquisa científica se inicia pelo levantamento (estudo, investigação) de artigos, livros e outras fontes acadêmicas (teses, anais de congressos) relevantes para uma questão particular, uma área de pesquisa ou teoria, fornecendo uma descrição, resumo e avaliação crítica de cada trabalho (LAKATOS; MARCONI, 1993).

As premissas da pesquisa são reformuladas com base na revisão bibliográfica desenvolvida com o propósito de efetuar a ligação entre o tema principal da pesquisa a ser desenvolvido e com o conhecimento compartilhado na comunidade científica e entre os interessados e envolvidos como um todo.

A Figura 1.2 mostra que a formalização da pesquisa está envolta de um conjunto de fundamentações conceituais capazes de definir teoricamente os aspectos da Avaliação de Segurança Crítica de VANT no Espaço Aéreo Controlado e Não Segregado.

A pesquisa realizada no setor de desenvolvimento de veículos aéreos não tripulados e sua possível integração no espaço aéreo controlado e não segregado destacou as seguintes frentes:

1) Órgãos Reguladores envolvidos;

O desafio principal dos órgãos reguladores para certificar um VANT está na falta de referências adequadas para uma avaliação de segurança e, consequentemente, uma certificação para VANT.

2) Comunidade Científica Especializada em VANT;

O desenvolvimento da Tese teve a participação de diferentes contextos relacionados ao tema, pois houve estudo e participação de eventos tanto de aviação civil tradicional (encontros científicos com instituições relacionadas, tal como ANAC e DECEA), como de comunidades dedicadas ao desenvolvimento de VANT (tal como o evento ICUAS de 2013). Também houve pesquisas e publicações em eventos dedicados a sistemas críticos (participação do autor no evento DSN 2009).

3) Avaliação de pesquisas relacionadas à Automação na Aviação Civil; 
O VANT Autônomo é um segmento novo na aviação civil, mas foi necessário entender, do ponto de vista dos atores da aviação civil, o significado de automático e autônomo. $\mathrm{O}$ autor participou de um estudo sobre sistemas autônomos por 5 meses na Universidade do Porto para desenvolver o conceito de VANT como entidade autônoma.

4) Avaliação do VANT do ponto de vista de Comando da Aeronave;

Buscaram-se pesquisas que mostrassem a visão de desenvolvedores, cientistas relacionados e interessados e envolvidos que estivessem focadas na validação de seus métodos do ponto de vista de Voo, Navegação e Comunicação do "Piloto" VANT com os demais atores da aviação civil.

5) Estudos de Métodos e Processos de Avaliação de Segurança Crítica para Sistemas Críticos;

Além de se ter uma visão sobre definições de VANT, a pesquisa científica realizada buscou por métodos que pudessem ser reutilizados de forma adequada ao tema de estudo.

Particularmente, para demonstrar a importância do tema desenvolvido nesta Tese, o ICUAS (International Conference on Unmanned Aircraft Systems) de 2013 teve 141 artigos científicos aceitos. Desse conjunto de artigos, apenas cinco artigos relacionados à regulamentação de VANT (ICUAS, 2013). O artigo apresentado teve forte aceitação pela audiência do evento, destacando a importância e carência de formas de avaliar a segurança crítica do VANT. Da mesma forma, na revista International Journal of Intelligent Unmanned Systems, das 7 revistas avaliadas pelo autor, 3 em 2013 e 2 em 2014, todos os artigos são relacionados ao desenvolvimento de técnicas de operação, sem menção à forma de como devem operar no espaço aéreo. 
Figura 1.2 - Fundamentações Conceituais para a Formação de Hipóteses da Tese

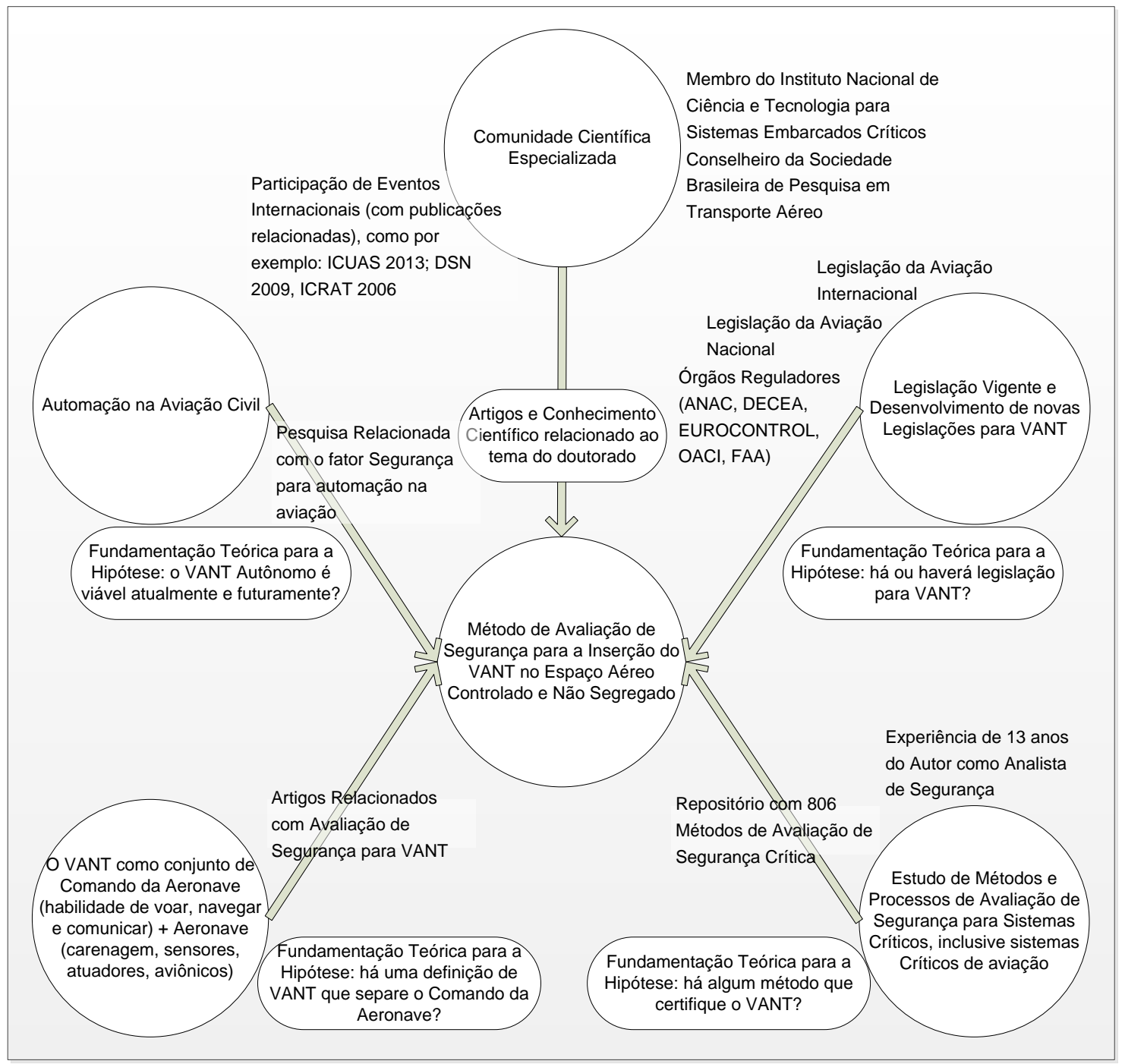

Fonte: Autor

Como resultados parciais das pesquisas desenvolvidas e realizadas ao longo da Tese, o autor desenvolveu publicações relacionadas ao tema Segurança Crítica e VANT que foram utilizadas para o embasamento dessa Tese em parceria com outros pesquisadores: Correa et. al (2006), Gil et. al (2010), Gimenes (2006, 2007, 2013, 2014), Gimenes; Almeida (2007, 2011), Gimenes et. al (2012), Oliveira; Gimenes e Almeida (2012).

Um destaque particular que contribuiu para o desenvolvimento da Tese, foi a participação do autor como membro do INCT-SEC - Instituto Nacional de Ciências e Tecnologia em Sistemas Embarcados Críticos de 2009 à 2013, de grande relevância nacional. Em Abril de 2013, o autor assumiu a coordenação do Grupo de Trabalho 3, responsável por desenvolver uma taxonomia de 
VANT. A missão do INCT-SEC foi de elevar e agregar habilidades, competências e infraestrutura necessárias para o desenvolvimento de sistemas embarcados críticos, com ênfase para veículos autônomos móveis. O INCTSEC visou capacitar a academia e a indústria brasileira no ensino, treinamento, pesquisa e desenvolvimento científico-tecnológico em aplicações de relevância e de alto impacto econômico-social em áreas estratégicas do país, a exemplo de aplicações na agricultura, segurança e defesa nacional, aviação e meio ambiente. O principal objetivo foi o desenvolvimento de pesquisas para a construção de sistemas embarcados críticos com ênfase para veículos autônomos móveis com o objetivo de serem transferidos para as empresas associadas, visando a possível fabricação e comercialização.

\subsection{Organização do Trabalho}

O capítulo 2 descreve os Veículos Aéreos Não Tripulados (VANT). Nesse capítulo, são descritos diferentes conceitos existentes sobre VANT, descrevendo como a tecnologia tem sido utilizada na automação de tarefas em aeronaves. Após apresentar a evolução da tecnologia utilizada, é apresentada uma definição de VANT que é adotada nesta Tese. O conceito de Espaço Aéreo Controlado e Não Segregado também é apresentado no capítulo 2 com o objetivo de permitir que o leitor compreenda o ambiente em que o VANT irá ser integrado. Apresenta-se a nova concepção do sistema de tráfego aéreo definido pela $\mathrm{OACl}$, os desafios que isto implica e como a OACI está prevendo o VANT nesta nova concepção.

No Capítulo 3 são apresentadas normas relacionadas à segurança crítica que apresentaram colaboração direta com o desenvolvimento desta Tese. Ainda nesse capítulo, são apresentados os conceitos necessários para compreender o método desenvolvido nesta Tese. 
O Método desenvolvido na Tese é apresentado no capítulo 4, ou seja, o desenvolvimento da do Método de Avaliação de Segurança proposto para que seja possível a utilização de VANT no Sistema de Navegação Aérea, em particular, o espaço aéreo controlado e não segregado. Nesse capítulo, também é apresentado o desenvolvimento da aplicação de exemplo de VANT Autônomo hipotético para a avaliação do método.

Finalmente, o capítulo 5 apresenta as conclusões do trabalho. 


\section{VEÍCULOS AÉREOS NÃO TRIPULADOS}

You see things; and you say "why?" But I dream things that never were; and I say "why not?"

-George Bernard Shaw

Neste capítulo, apresenta-se uma visão geral de como a tecnologia tem sido aplicada no desenvolvimento da aviação, envolvendo a automação de processos inicialmente operados pelo ser humano. Após esta introdução histórica, é apresentada a definição de Veículo Aéreo Não Tripulado (VANT) utilizada nesta Tese assim como o contexto do sistema de tráfego aéreo em que ele é considerado.

O desenvolvimento de VANT para uso civil, se comparado à aviação civil tradicional, ainda está em fase inicial. Porém, esta linha de desenvolvimento tem se mostrado bastante promissora quando se considera o avanço no controle de navegação de aeronaves. Soluções envolvendo inteligência artificial têm sido pesquisadas com o objetivo de desenvolver sistemas de tomada de decisão capazes de evitar colisões entre aeronaves (inclusive tripuladas) no espaço aéreo, em situações em que o ser humano não é capaz de reagir em tempo suficiente (SULLIVAN, 2005). O cuidado a ser tomado no projeto e implementação desses sistemas de automação deve levar em conta sua responsabilidade, de forma a garantir a segurança no sistema de tráfego aéreo. Em função de o VANT ser, de uma forma generalista, uma aeronave com um sistema automático de tomada de decisões, surgem novos fatores de segurança crítica quando se considera a possibilidade de utilizar tais aeronaves com passageiros ou carga e estas mesmas aeronaves compartilhando o espaço aéreo com outras aeronaves tripuladas (GIMENES; ALMEIDA, 2006).

Conforme Allouche (2000), para se operar um VANT no espaço aéreo controlado e não segregado, deve-se ter duas condições diretamente relacionadas: o VANT deve ser seguro e confiável o suficiente para voar sobre áreas densamente povoadas e deve ser operacionalmente seguro em todas as áreas do espaço aéreo (incluindo as etapas em solo). Apesar de ambos os requisitos serem definidos de forma genérica, eles consideram toda a abrangência de situações inseguras tanto para a aeronave em si como para o ambiente em que ela se encontra. 
Atualmente já existem aplicações em operação de VANT para uso civil, algumas delas em fase de desenvolvimento, comumente relacionadas a aplicações de vigilância ou ao acesso a áreas de risco, tais como plantas nucleares, manutenção de linhas de transmissão, entre outros (CIVILIAN, 1999), (GUPTA; GHONGE; JAWANDHIYA, 2013). Essas aplicações estão frequentemente isoladas do sistema de tráfego aéreo, voando em baixa velocidade e altitude e em áreas previamente autorizadas e segregadas.

O uso do VANT em aplicações civis tais como as citadas não está regulamentado, de forma que possa ser utilizado comercialmente pela indústria aeronáutica. Para que o uso do VANT seja regulamentado, há questões que ainda precisam ser estudadas: técnicas (tecnologias utilizadas e segurança), políticas (leis nacionais e controle de fronteira) ou legais (responsabilidades legais em caso de acidentes, seguros, entre outros). Particularmente, esta Tese explora a dimensão técnica por meio de um método que fornece suporte aos tomadores de decisão, de forma a melhor balancear a relação entre as demais dimensões, tal como proposto nos objetivos.

Essas questões, principalmente sob o aspecto de segurança para operar diferentes tipos de VANT em um espaço aéreo não segregado também devem estar de acordo com os regulamentos de segurança definidos pela OACI. Portanto, todos os fatores de segurança crítica devem ser avaliados em função de critérios definidos pelos órgãos reguladores da aviação civil.

\subsection{A Evolução da Automação em Sistemas Críticos na Aviação}

Nesta seção, apresentam-se os passos evolutivos mais relevantes da tecnologia na automação dos sistemas aviônicos. Por exemplo, realizando uma comparação de equivalência que, assim como o VANT representaria a substituição do humano na pilotagem, substituições semelhantes já ocorreram, tal como o papel do Engenheiro de Voo não mais necessário nas aeronaves comerciais atuais. Desde o início da aviação, houve outros casos de automação na aviação civil, tal como representado na Figura 2.1. O uso de sistemas hidráulicos no início da indústria aeronáutica permitiu que aeronaves maiores fossem construídas, amplificando os comandos do comandante. Pode- 
se entender que tais sistemas hidráulicos representaram uma forma inicial de automação, pois há uma conversão de sinais de comandos entre o comandante e os atuadores da aeronave.

A evolução aérea seguiu definindo-se as regras de voo visual (VFR - Visual Flight Rules) e, com a evolução de tecnologia, as regras de voo por instrumento (IFR - Instrument Flight Rules), obrigando uma nova forma de voar por parte dos pilotos, pois tarefas feitas em VFR passaram a ser realizadas por equipamentos eletrônicos. Uma mudança significativa realizada na automação de controles de uma aeronave foi o desenvolvimento do conceito Flight By Wire. Em uma tradução livre, o Flight By Wire pode ser entendido como o Voo por Cabos Elétricos. O significado lógico do termo foi definir que os comandos do piloto primeiramente passam por um computador de bordo que avalia o comando e o traduz para os atuadores das aeronaves qual a melhor forma de realizá-lo.

Além de eliminar o Engenheiro de Voo, o avanço desses computadores de bordo também passou a limitar ou mesmo censurar comandos de pilotos, comandos esses julgados como errados. Supondo que o comandante altere o posicionamento do joystick da aeronave controlada por Flight by Wire de forma brusca, o que poderia levar a aeronave a um estado de perda de sustentação, as aeronaves traduzem esse comando de forma a atender o comando sem levar ao estado inseguro.

A evolução da tecnologia das aeronaves associadas às tecnologias de solo permitiram desenvolver sistemas de pouso e decolagem automáticos, tal como o pouso que é obrigatoriamente autônomo chamado de Categoria Illc. Tecnologias ainda restritas ao campo experimental mostram a evolução da aviação tal como o conceito Flight By Wireless. Esse conceito busca substituir o cabeamento interno da aeronave por sinais sem fio, inclusive para o controle das turbinas da aeronave (THOMPSON, 2009). 
Figura 2.1 - Evolução da Automação na Aviação

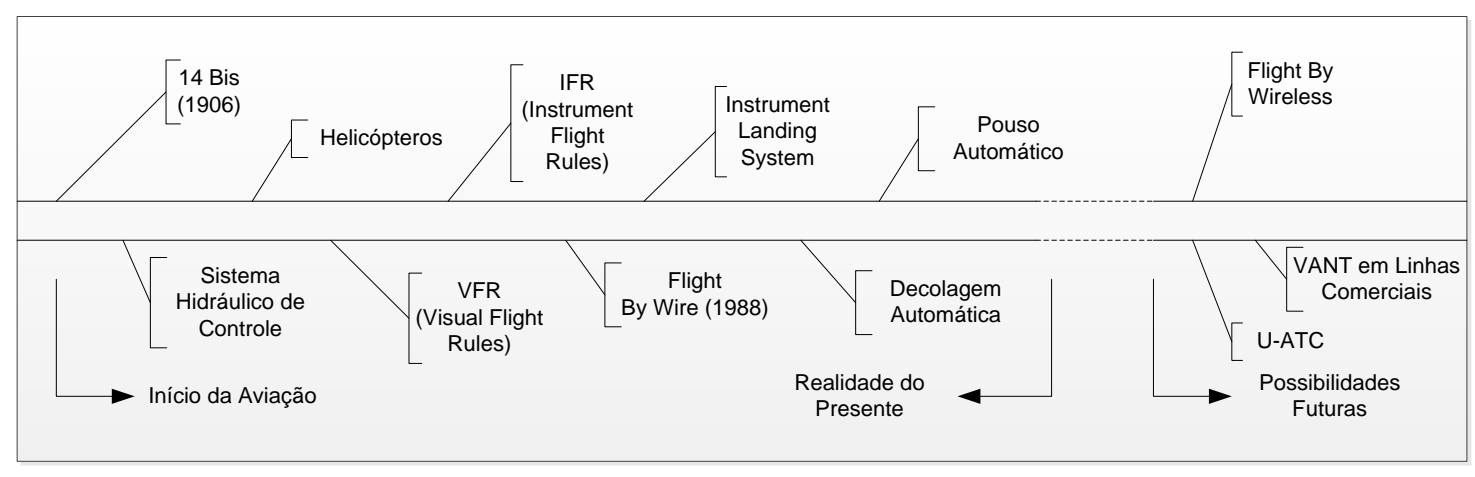

Fonte: Autor

A preocupação com o crescimento da demanda pelo transporte aéreo e a necessidade de torná-lo cada vez mais seguro têm exigido um constante desenvolvimento por novas soluções. Esta preocupação pode ser notada na implantação da Concepção Operacional do ATM Global definida pela OACl em sua décima primeira conferência de Navegação Aérea (ICAO, 2013), em que apresentaram a necessidade de estudos dedicados aos VANT do ponto de vista dos órgãos governamentais reguladores.

\subsection{Panorama Atual}

Considerando a prática feita no Brasil, uma aeronave que deseja voar no espaço aéreo brasileiro deve estar certificada pela ANAC e, em posse dessa certificação, requerer autorizações de todos os voos que ela for efetuar perante o Departamento do Controle do Espaço Aéreo (DECEA), seja ela tripulada ou não. Conforme a RBAC 01 da ANAC (ANAC, 2011a), define-se uma aeronave como "um dispositivo que é usado ou que se pretenda usar para voar na atmosfera, capaz de transportar pessoas e/ou coisas". A partir dessa definição, pode-se concluir que, se um aeromodelo originalmente desenvolvido para uso recreativo for utilizado para fins comerciais (por exemplo, transporte de carga), ele se torna uma aeronave que deve seguir as regras impostas pela ANAC e pelo DECEA em relação ao espaço aéreo que ele voará. A ANAC, apesar de ser responsável pela certificação, não tem equipes de desenvolvimento de aeronaves, cabendo a ela apenas a responsabilidade de certificá-las.

Tendo em vista as exigências atuais da aviação civil, a missão atual da ANAC e do DECEA é a de desenvolver um caminho que seja um ponto de referência, 
a partir de práticas existentes e bem estabelecidas, que são utilizadas em outros domínios e aplicações do Gerenciamento de Tráfego Aéreo e, então, adaptá-los para a integração de VANT.

Apresentando o contexto internacional que o DECEA e a ANAC estão estabelecidos, o desenvolvimento seguro e ordenado da aviação civil internacional é promovido pela Organização da Aviação Civil Internacional (OACl), também conhecida em inglês por International Civil Aviation Organization (ICAO), agência especializada das Nações Unidas.

A OACI tem a missão de estabelecer normas e regulamentos necessários para a segurança crítica, segurança da informação, eficiência e regularidade, bem como para a proteção ambiental da aviação. A Organização serve como fórum para a cooperação em todos os domínios da aviação civil entre seus 191 Estados-Membros (os mesmos membros da ONU). A regulamentação da OACI está baseada na Convenção de Chicago (Convention on International Civil Aviation) (ICAO, 1944). Esta convenção foi assinada em 07 de dezembro de 1944 por 52 Nações. Após todas as nações ratificarem a Convenção de Chicago, foi estabelecida a OACI, em 04 de abril de 1947.

Com o objetivo de garantir o compartilhamento do espaço aéreo de diferentes estados, a OACI produziu documentos que regem a aviação civil internacional. Como destaque no aspecto dos Veículos Aéreos Não Tripulados (VANT), pode-se apontar o artigo 8으 (ICAO, 1944): "Nenhuma aeronave capaz de voar sem um piloto deve voar sem um piloto sobre o território do Estado contratante sem autorização especial deste Estado e em acordo com os termos de tal autorização...". Os demais documentos anexos à Convenção não se referem a aeronaves não tripuladas.

A Circular 328 da OACI (ICAO, 2011) define o VANT como sendo uma aeronave e seus demais elementos associados que são operados sem piloto a bordo. A Circular 328 também reforça que o VANT, em função das limitações impostas pela $\mathrm{OACl}$, deve voar sob o comando de um piloto remotamente localizado em uma central de operação. A Circular 328 define que este tipo de aeronave seja um subgrupo de VANT, designada pelo termo Aeronave Remotamente Pilotada (Remotely-Piloted Aircraft - RPA). 
A ANAC e o DECEA têm investido em grupos internos e também internacionais para estarem sincronizados com as instituições internacionais sobre a melhor forma de lidar essa nova tecnologia. Ambos são responsáveis pela realização do trabalho de certificação e autorização de voo de aeronaves, independente de ser remotamente pilotada ou não. Essa responsabilidade que ambos possuem perante a sociedade internacional os obriga a definir novos procedimentos de certificação e autorização de voo para VANT.

Para exemplificar, tanto a ANAC quanto o DECEA possuem representantes no grupo de trabalho denominado por UASSG (Unmanned Aircraft Systems Study Group ou Grupo de Estudos Sobre Aeronaves Remotamente Pilotadas) da OACI (UASSG, 2012). Conforme declarado no portal do DECEA (DECEA, 2012), o Major Cyro André Cruz, membro brasileiro do Grupo de Estudo internacional e atual Comandante do $2^{\circ} / 1^{\circ}$ GCC afirmou:

"[...] assunto em pauta [VANT] ainda é muito recente na aviação e requer muito estudo, muitas definições. Estamos tendo a oportunidade de discutir essas questões tão complexas e dar uma visibilidade da importância que o Brasil dá ao tema. As aeronaves remotamente pilotadas hoje são uma realidade e precisam ser reguladas".

O UASSG e demais grupos de trabalho, seguindo a diretriz da Circular 328 (ICAO, 2009) da OACI, têm considerado que o VANT não pode ser completamente autônomo e que seja sempre pilotado remotamente por um piloto humano. Por outro lado, por não haver um piloto a bordo, é necessário que o VANT tenha algum sistema de salvaguarda em caso de perda de comunicação. Fazendo uma analogia com uma aeronave comercial tripulada, se o piloto ficar impossibilitado de exercer sua função, há o copiloto para tal emergência. Mas há os casos em que não há copiloto. No caso do VANT (RPA), essa situação é reproduzida no caso de perda de comunicação da aeronave com o piloto em solo. Portanto, do ponto de vista de segurança crítica, um VANT deve possuir algum procedimento de pouso automático ou de retorno para a base. 
Apesar das limitações existentes, alguns avanços importantes estão sendo feitos no setor de certificação. A ANAC emitiu, em maio de 2013, o primeiro Certificado de Autorização de Voo Experimental (CAVE) para um Veículo Aéreo não Tripulado (VANT) para uma empresa privada no Brasil, utilizando-se do documento ANAC IS 21-002A (ANAC, 2012a, 2012b). De posse de um CAVE, a empresa possuidora do VANT pode requerer junto ao DECEA autorizações para seus planos de voo.

Seguindo a linha de trabalho realizado pela ANAC, há a demanda por processos colaborativos que demonstrem que a aeronave é segura, confiável e disponível por parte dos órgãos reguladores e autoridades certificadoras governamentais ainda é um campo aberto e necessário. A abordagem da Tese é, então, focada em um método que avalie as implicações de segurança que esse tipo de aeronave gera em um espaço aéreo controlado e não segregado. Com base nessa linha de raciocínio, focaram-se os estudos em métodos e técnicas com o objetivo de colaborar com as autoridades aeronáuticas responsáveis pela autorização e certificação de aeronaves.

Outro importante fator que tem preocupado as autoridades aeronáuticas mundiais são as questões jurídicas ainda mal resolvidas tanto no Brasil quanto no mundo. Diversas abordagens e desafios relacionados ao uso de VANT estão bem apresentados na revista Computação Brasil (COMPUTAÇÃO, 2014). Um desafio constante de empresas que querem operar com VANT é conseguir a aprovação de seguradoras para suas aeronaves (ainda experimentais). Quando considera-se a hipótese de uma aeronave não tripulada cair e, consequentemente, ferir alguém, é compreensível que as seguradoras tenham receio de se envolverem nesse nicho. A razão principal desse receio vem da falta de legislação específica.

O Brasil, Estado membro da $\mathrm{OACl}$, tem participado das reuniões internacionais para a busca de leis e regras que venham a regular o uso de VANT no domínio civil. As regras da aviação civil brasileiras e internacionais não permitem o uso de VANT para uso comercial exatamente por falta de regulamentação. Apesar de a ANAC ter apresentado o conceito de Certificado de Autorização de Veículo Experimental para que as empresas desenvolvedoras possam testar 
suas aeronaves, é importante ressaltar que o uso comercial, seja qual for, é proibido tanto pela ANAC quanto pelo DECEA.

A complexidade envolvida no uso do VANT também se expõe na visão de órgãos internacionais certificadores tais como a Eurocontrol (organização intergovernamental constituída pelos Estados Membros da União Europeia) que tem feito projeções de uso de VANT completamente integrado no espaço aéreo para o ano de 2050 (EUROCONTROL, 2013). Esse tipo de projeção associado à falta de metodologias para a avaliação da segurança crítica de VANT faz com que esta Tese esteja sendo desenvolvida na fronteira do conhecimento da avaliação do VANT no espaço aéreo controlado e não segregado. A pesquisa da literatura relacionada tem permitido identificar as características que dependem do controle humano. Essas características, quando vistas no contexto de um VANT, devem ser avaliadas e certificadas pelas autoridades da aviação civil, utilizando-se novos métodos ainda inexistentes.

Apesar de as premissas serem detalhadas no decorrer desta Tese, duas hipóteses merecem menção: considerou-se como hipótese principal que a integração de VANT no Sistema de Navegação Aérea deva atender os mesmos níveis de segurança já existentes da aviação civil e; o VANT a ser testado deve atender aos requisitos mínimos necessários para operar em um espaço aéreo controlado e não segregado, ou seja, este trabalho não tem o objetivo de apresentar ou propor a criação de um VANT real.

Um cenário válido a ser utilizado nesta Tese para contextualizar o VANT se baseia no cenário atual de interesse nacional presente na "Concepção Operacional ATM (Air Traffc Manangement) Nacional" apresentada pelo Comando da Aeronáutica Brasileira (DECEA, 2011). Esse documento apresenta a estratégia de transição destinada a contribuir para a Comunidade da aviação civil, em curto e médio prazo, baseada na infraestrutura de navegação aérea e na capacidade das aeronaves existentes e previstas. Desta forma, a utilização da Concepção Operacional ATM Nacional permite que seja realizada uma aplicação da extensão proposta nesta Tese para a validação da mesma na inserção de VANT no Sistema de Navegação Aérea. 
Situações de perigo tais como uma aterrissagem da emergência sem uma pista de decolagem, a falta de combustível em altitude de cruzeiro, ou uma falha qualquer de equipamento dentro da aeronave são situações críticas que este estudo propõe considerar e avaliar do ponto de vista da segurança crítica, uma vez que o VANT estará imerso em um meio não previsível, não sendo possível prever todos os tipos de falha do mundo real.

\subsection{Definição de VANT}

O VANT, Veículo Aéreo Não Tripulado, apesar de ter um nome bastante indicativo de seu significado, não possui uma definição única por parte da comunidade científica. Nessa comunidade não há a definição de uma fronteira entre Aeromodelo e VANT. No Brasil, um VANT que trabalhe no campo de visão, em área não populosa, sem fins lucrativos para uso apenas de recreação se enquadra na legislação de Aeromodelo (ANAC, 2011a). Uma diferença jurídica considerando um aeromodelo é de que, a partir do momento que esse aeromodelo é utilizado para uso comercial ou alguma aplicação que não seja recreação, é classificado como VANT.

Para melhor compreender o significado de VANT adotado nesta Tese, é feita uma descrição sobre as definições de VANT existentes perante as autoridades governamentais, um cenário de classificações de VANT utilizadas pela comunidade envolvida e interessada com o tema e, perante esse arcabouço, é apresentada a definição utilizada nesta Tese.

\subsubsection{Definição de VANT pelas Autoridades Governamentais}

Atualmente, o VANT definido pelos órgãos reguladores (ICAO, 2011; DECEA, 2010), consiste em três partes:

- VANT, sendo a aeronave propriamente dita, que deve possuir capacidade de voar de modo automático, caso não receba comandos da base remota;

- Enlace de Comunicação de Dados: responsável por transmitir os comandos da base para a aeronave, assim como a telemetria da aeronave para a base; 
- Base de Solo com o piloto humano remoto: responsável por comandar o VANT.

A Eurocontrol sugere uma hierarquia a ser seguida em operações de voo com a utilização de voos visuais ou por instrumentos, sendo que, primeiramente, o ATC deve estabelecer a separação e prevenir possíveis colisões entre aeronaves, inclusive os VANT (EUROCONTROL, 2007).

Segundo uma visão militar apresentada em Cohen; Segel (2001, p.305), um VANT é definido como sendo uma aeronave que está equipada e será recuperada ao final do voo. Esta definição visa distinguir um VANT de um míssil que, apesar de voar até o alvo sem piloto, possui a característica de se destruir ao final da missão.

O DECEA define VANT na Circular de Informações Aéreas AIC N 21/10 (DECEA, 2010) como um veículo aéreo projetado para operar sem piloto a bordo, que possua uma carga útil embarcada e que não seja utilizado para fins meramente recreativos. Nesta definição incluem-se todos os aviões, helicópteros e dirigíveis controláveis nos três eixos, excluindo-se, portanto, os balões tradicionais e aeromodelos (DECEA, 2010). Para o DECEA, o VANT é uma categoria de aeronave reconhecida e como tal, tem de ser pilotado. DECEA define que o controle desse tipo de aeronave pode ser exercido diretamente por um piloto localizado em uma estação remota de pilotagem (aeronave remotamente pilotada) ou indiretamente através de programação (aeronave autônoma).

O entendimento do DECEA é que apenas as aeronaves remotamente pilotadas estão autorizadas a acesso ao espaço aéreo brasileiro. A definição regida pelo DECEA segue as orientações da OACl que define VANT como: uma aeronave, em acordo com o Artigo 8 da Convenção Internacional de Aviação Civil, que voa sem um piloto no comando a bordo, e é também remota e totalmente controlada a partir de outro local (em solo, outra aeronave, espaço) ou programada e totalmente autônoma (ICAO, 2004). A ANAC definiu a Instrução Complementar 21-002 (ANAC, 2012b) para VANT definido pelo DECEA com base no Regimento da Aviação Civil 21 - RBAC 21 (ANAC, 2011b). 
Apesar dessa definição vigente na legislação brasileira, existem diferentes definições apresentadas na comunidade científica, na qual a definição de VANT é normalmente baseada na altitude em que o VANT consegue voar, no seu tamanho e também na carga útil que pode transportar.

\subsubsection{Categorias de VANT}

A descrição e categorização de VANT podem se feitas de acordo com muitos critérios, tais como altitude de voo, resistência, vigilância e tamanho, entre outros. Para o meio aeronáutico, o termo resistência é um jargão que transmite o significado de robustez, confiabilidade e disponibilidade por um determinado período de voo (LAX, 1996).

Há algumas tentativas de agrupamentos de VANT em níveis, mas há uma variedade de agrupamentos em que a sobreposição deles é inevitável. Com o objetivo de minimizar tal inconveniente, o International Forum on UAV, (GIMENES, 2007) propôs um conjunto de descrições baseadas em características de voo, tamanho/peso e funcionalidade como apresentado a seguir:

- $\quad$ "VANT Resistente": aeronaves que podem voar com autonomia de mais de 24 horas. Elas podem ser classificadas como operacionais (altitudes médias, entre 5 e 11 mil pés) e estratégicas (superando os 20 mil pés);

- Micro VANT: pequenas aeronaves, usualmente limitadas para missões de curto alcance. Operam em baixa altitude (abaixo de 5 mil pés) e pesam menos de um quilograma.

- Mini VANT: aeronaves com grande autonomia que operam em altitudes intermediárias. Podem alcançar o limite do espaço aéreo controlado (18 mil pés). Em sua maioria, pesam entre $1 \mathrm{~kg}$ e $20 \mathrm{~kg}$.

- VANT Tático: veículos militares, podendo voar em altitudes intermediárias (entre 5 e 11 mil pés). Tipicamente, seu peso varia entre 20 kg e 450 kg e possuem grande autonomia.

Pode-se notar que esta classificação possui uma herança militar, uma vez que a área militar tem tido o maior envolvimento no desenvolvimento de VANT. 
Dado que o foco militar é remover o ser humano da aeronave, de forma a minimizar a perda de pilotos em caso de combate, caso a aeronave tenha problemas, a perda de equipamento não é crítica como a perda de seus membros. Outro dilema que tem sido abordado é o uso de VANT militar com armamento a bordo, uma vez que há requisitos de confiabilidade e segurança sobre o algoritmo responsável pelo acionamento do armamento (SULLIVAN, 2005), de forma a evitar seu acionamento sobre áreas aliadas, evitando-se assim o fratricídio.

Em oposição a essa visão militar, o VANT para aplicação civil, em que há a possibilidade de se ter passageiros a bordo, apresenta requisitos de segurança e visa exatamente a preservação da aeronave em situações críticas. Em função deste ponto de vista, novas barreiras se formam para a categorização de VANT com passageiros e compartilhando o espaço aéreo controlado e não segregado.

Mais importante que uma classificação em função dos tipos de aeronave que existem ou estão sendo desenvolvidas, o foco desta Tese é o conceito geral apresentado pela OACl e o que o VANT deve possuir como requisito mínimo necessário para voar de forma segura em um ambiente controlado e não segregado, independente de suas características de construção.

\subsubsection{VANT como Aeronave Controlada por Sistema Autônomo de Pilotagem}

Entende-se por VANT nesta Tese uma aeronave que não depende de haver uma tripulação para que essa mesma aeronave seja capaz de realizar um voo completo (incluindo todas as etapas de um voo) de forma autônoma controlada por um Sistema Autônomo de Pilotagem (SAP) a bordo da aeronave. Além disso, ela deve ser capaz de interagir com o Controle de Tráfego Aéreo para que possa voar em um espaço aéreo não segregado. 
A motivação de utilizar esta definição foi baseada em dois fatores:

- Um VANT controlado por um SAP é entendido como o pior caso do ponto de vista de segurança crítica; e

- Todo VANT precisa ter um estado seguro de voo autônomo, caso haja a perda do enlace de comunicação.

Em vista também da avaliação das aeronaves tripuladas modernas, surge 0 questionamento de se existir uma zona mista na fronteira entre as aeronaves tripuladas atuais, tais como Boeing 777 ou Airbus A380 e os VANT em desenvolvimento, sejam projetos civis ou militares (tal como o projeto americano Global Hawk). As aeronaves modernas são equipadas com sistemas automáticos de auxílio ao voo, tais como sistemas de controle de propulsão e piloto automático. Por exemplo, a aeronave militar US F-117 não possui capacidade de voar somente com o controle realizado pelo piloto, que assume o dever da navegação mas não da capacidade de voar (do ponto de vista de sustentação no ar) (AVANZINI; MINISCI, 2010). A aeronave F-117 apresenta significativa instabilidade aerodinâmica. Portanto, o sistema automático de sensores e controle dos atuadores distribuídos pela superfície da aeronave garante o ajuste e controle em tempo real de sustentação de voo.

No meio científico, há diferença significativa entre esses dois cenários de aeronaves, mas, ao mesmo tempo, eles estão próximos o suficiente para que haja a possibilidade de considerar o uso futuro de VANT para o transporte de passageiros.

Mesmo em um pouso totalmente automático, há a supervisão humana externa, além dos pilotos que estão observando todos os movimentos e decisões da aeronave, podendo, assim, arremeter em caso de dúvida ou de uma situação inesperada. Independente do tipo de automação existente nas aeronaves atuais, o controle delas está sob a tutela dos pilotos que são os responsáveis pelo voo. Utilizar a automação existente nas aeronaves atuais tripuladas é uma vantagem para o desenvolvimento de um VANT, mas ainda permanece a principal diferença: a automação também deve assumir a responsabilidade pela tomada de decisões em todas as etapas de um voo. 
Um piloto tem por responsabilidade voar, navegar e comunicar e, para realizar essas tarefas ele é treinado, avaliado e, consequentemente, habilitado (certificado) para tomar decisões precisas e seguras e comunicá-las às autoridades de gestão do tráfego aéreo, no aguardo de autorização ou instruções para pô-las em prática. Um piloto humano navega e comunica e, o voo propriamente dito, fica a cargo, em grande parte, da automação existente nas modernas aeronaves.

Pode-se observar que o mais adequado, para as aeronaves atuais tripuladas, não seria considerá-las como Aeronaves Autônomas ou não, mas sim sua capacidade de voar autonomamente ou não. O questionamento, então, referese a quem voa, navega e comunica, já que, em uma visão simplista, pode ser tanto um piloto humano quanto um sistema autônomo ou, ainda, uma combinação de ambos. Esse é o ponto central para se considerar uma nova taxonomia para os VANT apresentada na Figura 2.2.

O Anexo I da OACI (ICAO, 2001a) define Aeronave como qualquer máquina que consiga produzir uma sustentação na atmosfera devido às reações do ar, exceto as reações do ar contra a superfície da Terra. Avião é um subtipo de aeronave definido como uma aeronave mais pesada que o ar com propulsão motorizada, cuja sustentação em voo se deve principalmente a partir de reações aerodinâmicas exercidas sobre superfícies que permanecem fixas em determinadas condições de voo. Esta Tese utiliza-se destas definições consagradas, sem a necessidade, desta forma, de apresentar alguma nova definição a respeito.

Quando há um piloto em solo comandando remotamente a aeronave, há o desafio de se garantir a comunicação entre a estação de controle e a aeronave. Os aspectos de segurança crítica relacionados com esta comunicação geram requisitos de desenvolvimento. Estes requisitos, por exemplo, devem ser considerados em casos de emergência, tal como em uma situação de perda de comunicação com o piloto, a aeronave deve ser capaz de contornar uma ação de emergência sem um piloto.

A demanda por VANT provocada pela indústria tem gerado cobranças perante as instituições governamentais (por exemplo, a ANAC no Brasil e FAA nos 
EUA) e instituições internacionais (como, por exemplo, a OACl e a Eurocontrol) para que estas desenvolvam uma regulamentação para a operação de VANT, relacionada, sobretudo, aos riscos que este novo conceito de aeronave pode representar à sociedade (DALAMAGKIDIS; VALAVANIS; PIEGL, 2012, p. 132). A regulamentação tem como aliada a evolução tecnológica na aviação civil, que tem oferecido novos recursos, tais como a comunicação digital por CPDLC (Controller-Pilot Data Link Communications) que poderá ser utilizada nos futuros VANT. Mas tem-se observado que as questões tecnológicas não são as únicas limitações.

Os desafios da integração do VANT no espaço aéreo, segregado ou não, estão relacionados à regulamentação ainda muito rígida em função da carência de provas científicas de que este novo conceito de aeronave pode voar de modo seguro.

\subsubsection{VANT - Taxonomia Adotada}

Esta seção apresenta uma taxonomia que separa os elementos de navegação, controle e comunicação relacionados ao ato de voar da aeronave em si apresentado na Figura 2.2. 
Figura 2.2 -Taxonomia para VANT

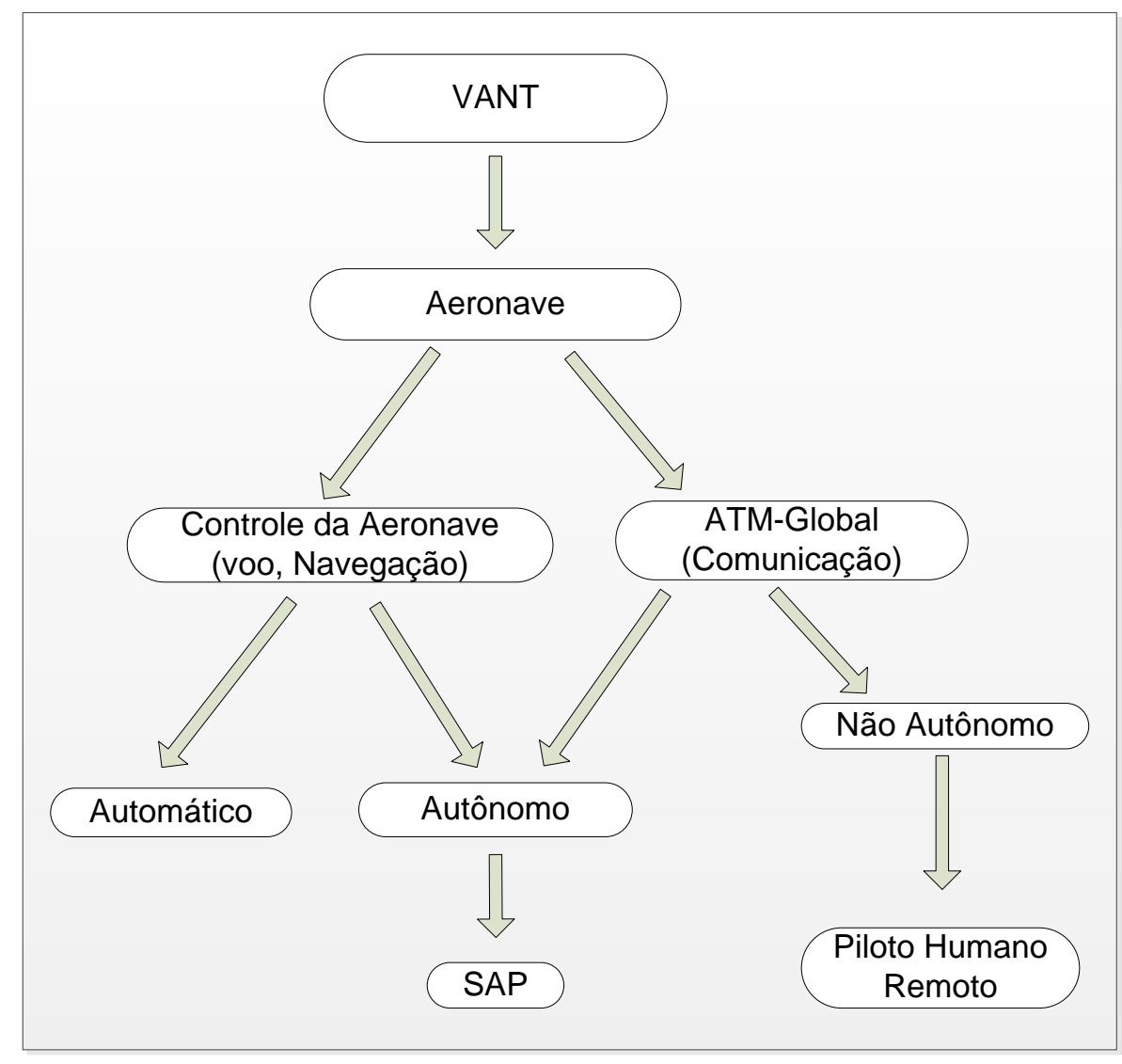

Fonte: Gimenes (2012)

Em geral, no domínio da pesquisa acadêmica, tem-se observado um forte investimento em soluções para gerar novos controles de VANT, assim como novos tipos de aeronaves que sejam fisicamente mais adequadas às particularidades desses VANT.

Em complemento à taxonomia apresentada, esta Tese visa apresentar um método para a certificação de um Sistema Autônomo de Pilotagem (SAP). A base desta abordagem é apresentar a separação entre o Sistema Autônomo de Pilotagem e a aeronave. Esta separação é viável, pois, na aviação civil, o processo de certificação de aeronaves é consagrado, independente do piloto a bordo (seja autônomo ou humano) (GIMENES, 2012).

O SAP é definido a partir de uma proposição de critérios que visam a padronização e validação (certificação) dos elementos necessários para a operação segura do VANT em função do risco que a aeronave autônoma apresenta. 
A realização de experimentos práticos com candidatos a SAP ainda é algo que requer autorização especial de voos experimentais, mesmo em espaço aéreo segregado.

Em função da taxonomia apresentada, o conceito descrito por esta Tese visa estabelecer novos critérios para a definição destas aeronaves, assim como também apresentar o VANT como uma aeronave como todas as outras do ponto de vista aeronáutico. A Figura 2.3 apresenta uma visão do Sistema de Gerenciamento do Espaço Aéreo considerando a presença de um VANT (GIMENES, 2014), uma aeronave tripulada e o Sistema de Tráfego Aéreo (ATC - Air Traffic Control). O VANT é composto pelo SAP embarcado em uma aeronave (VANT Autônomo). Caso ele fosse Não Autônomo, há o elemento Piloto Humano Remoto em Estação de Solo, configuração que é definida pelo DECEA como SISVANT (Figura 2.3) (DECEA, 2010). Uma aeronave tripulada depende de um piloto que a comanda que, por sua vez, conta com um piloto automático.

Figura 2.3 - Perspectiva do ATC na presença de VANT e Aeronaves Tripuladas

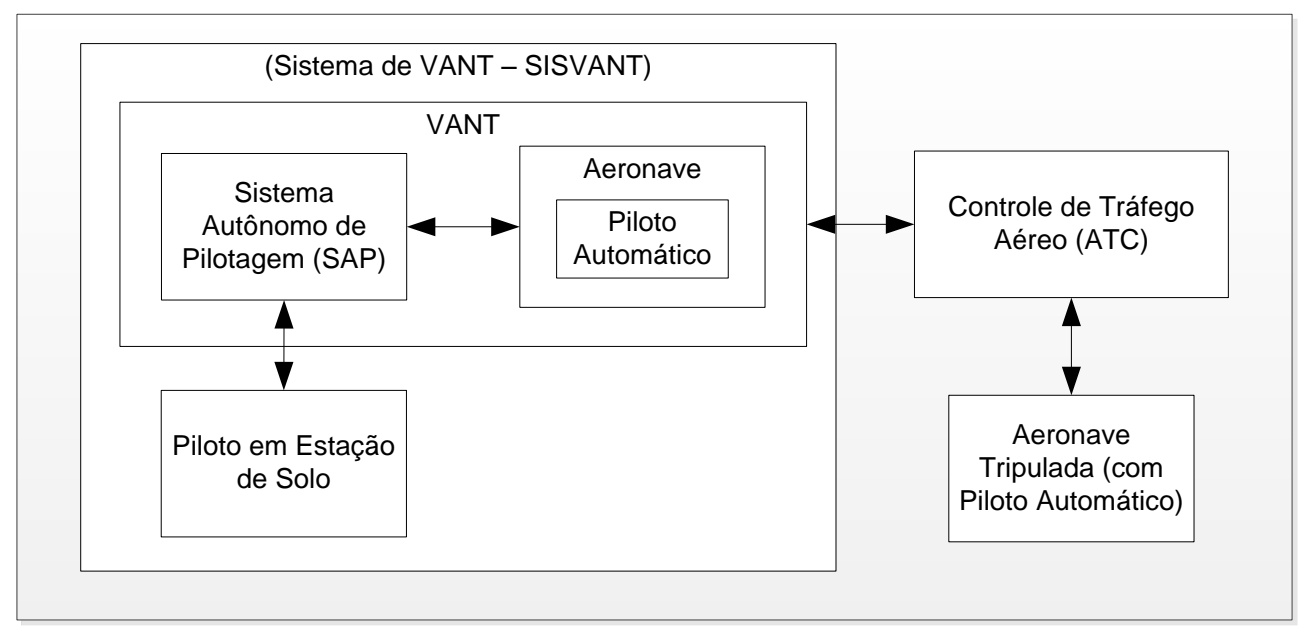

Fonte: Gimenes (2014)

Para separar o conceito de SAP do VANT (aeronave que depende de um "piloto" SAP, mas que, assim como a aeronave tripulada, possui um piloto automático), dois conceitos são introduzidos: sistema automático e sistema autônomo.

Um sistema automático executa indefinidamente um conjunto de tarefas de acordo com parâmetros pré-definidos por um comandante, da mesma forma 
que o comandante atua nos comandos da aeronave quando ela não se encontra em modo automático. O Piloto Automático é considerado um sistema automático, pois não possui habilidade de navegar, mas controla a aeronave sobre um conjunto de instruções de voo fixos (KUO, 1987).

Um sistema autônomo é definido como um sistema que pode atingir seus objetivos sem um controle externo (tal como um piloto remoto em uma base em solo). Um VANT autônomo (VANT controlado pelo SAP) pode avaliar e assumir decisões necessárias para certas ações e então aplicá-las, ou seja, o "piloto" SAP realiza as tomadas de decisão no VANT autônomo (COHEN, 2001).

Portanto, considerando que o VANT utilizado nessa Tese seja o VANT Autônomo, ele é constituído de:

1) Aeronave (com os sistemas aviônicos incluídos, inclusive o Piloto Automático);

2) O Sistema Autônomo de Pilotagem (SAP); e

3) Procedimentos de Voo de acordo com as regulamentações do ATM Global.

Dependendo da filosofia adotada, o modelo de VANT pode considerar a integração do Piloto Automático pelo SAP, sendo que o SAP executa todas as funções de ambos os módulos. No que tange ao controle automático, o sistema de piloto automático de bordo tem definições e regulamentos estabelecidos pelos sistemas aviônicos, indústrias e agências reguladoras. No entanto, as circunstâncias são diferentes para controle autônomo, que ainda não tem um consenso. Portanto, uma descrição do SAP como um possível substituto para pilotos humanos deve ser incluída como parte do novo conceito VANT. O SAP deve executar os procedimentos de navegação e comunicação durante o voo, deixando a tarefa de manter o cruzeiro para os equipamentos automáticos que já estão disponíveis em aeronaves modernas.

No que diz respeito à atividade voo, em conformidade com os regulamentos da aviação, uma aeronave que executa um voo no espaço aéreo não segregado não deve interferir no gerenciamento de espaço aéreo de forma diferente às demais aeronaves. Uma aeronave autonomamente operada deve ser capaz de 
interagir com as autoridades aeronáuticas e com as outras aeronaves que compartilham o mesmo espaço aéreo. Para este efeito, deve-se utilizar tecnologias como o enlace de comunicação digital (Digital Datalink). Assim, a entrada de uma aeronave autônoma em um espaço aéreo controlado e não segregado deve ocorrer de forma transparente aos Controladores de Tráfego Aéreo, da mesma forma que uma aeronave tripulada o faria.

O VANT pode ser definido independentemente da missão ou a carga útil da aeronave, pois, na visão desta Tese, deve ser considerado como uma aeronave. A Figura 2.4 apresenta essa visão de VANT como aeronave. Assim como uma aeronave tripulada, os elementos de voo e de interface são conceitos bem definidos pela aviação civil e, portanto, deve-se considerar o uso desses mesmos elementos, independentemente do Comandante da Aeronave. Para se distinguir entre uma Aeronave Tripulada Convencional, um VANT Autônomo e um VANT Remotamente Pilotado, a diferença está no fato de haver ou não um SAP embarcado, um Piloto a bordo ou um Piloto em Base Remota. Essas aeronaves já possuem os requisitos básicos para voo e, assim, o foco de desenvolvimento volta-se para a necessidade de se implementar critérios e requisitos de segurança para o elemento SAP embarcado no VANT, que tem a missão de substituir o piloto humano. 
Figura 2.4 -VANT Visto como Aeronave

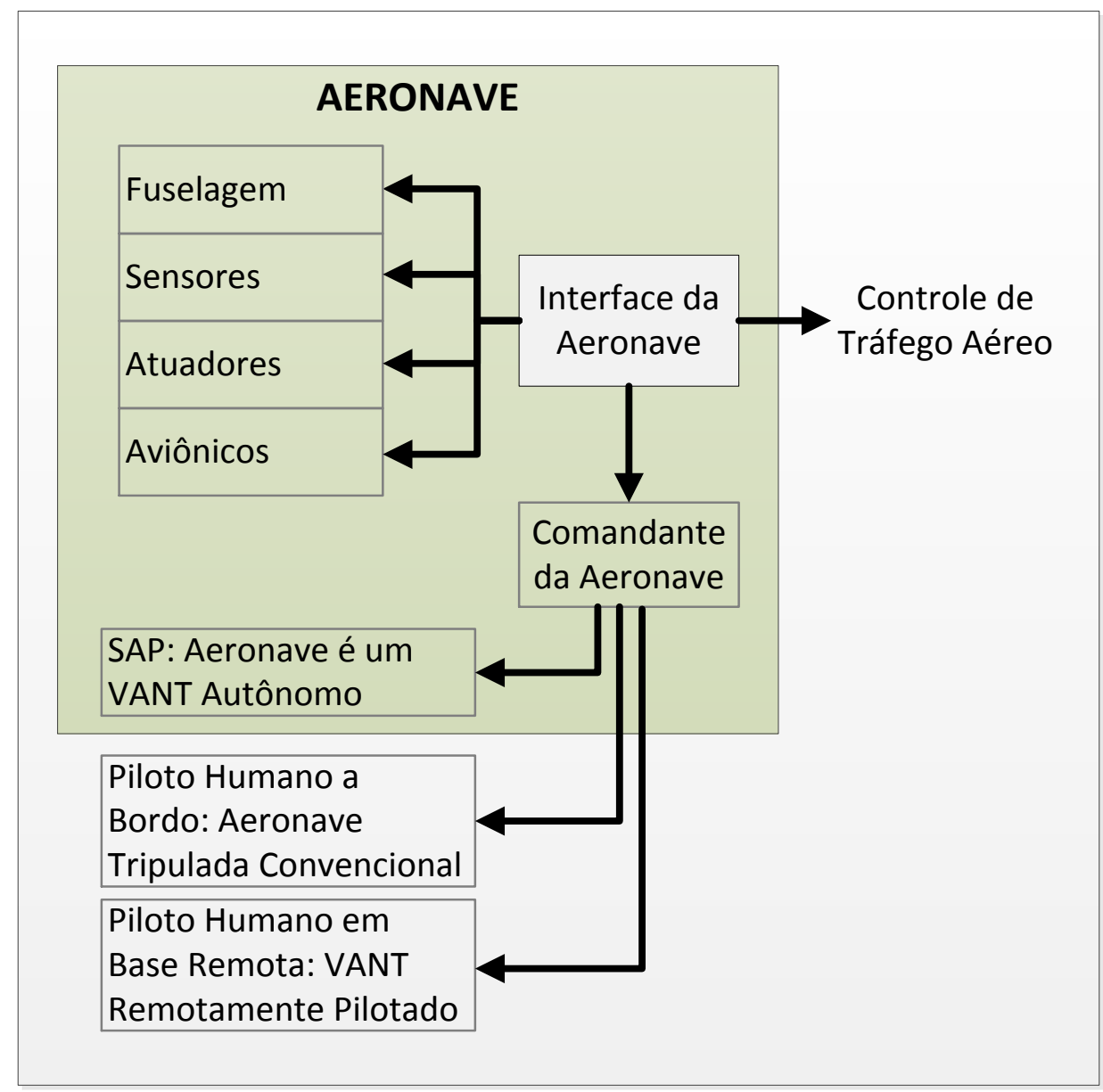

Fonte: Autor

Considerou-se, então, que o VANT deve ser certificado no pior cenário possível, ou seja, considerou-se que o VANT é completamente autônomo e deve ser capaz de voar, navegar e comunicar com o ATM de forma transparente. A circular $\mathrm{OACl}$ considera que toda aeronave não tripulada deve ter um piloto humano que a controla remotamente. Essa restrição tem de prever a exceção não definida na circular $\mathrm{OACl}$ de perda de comunicação entre o piloto remoto e a aeronave. Nesse momento de perda de comunicação, a aeronave se torna autônoma e os procedimentos de emergência não podem considerar que somente ela está no espaço aéreo e que é a única aeronave sem controle remoto, de forma que todas as outras aeronaves sejam desviadas.

Um cenário crítico de segurança a ser avaliado nesta taxonomia é considerar que, havendo mais de uma aeronave remotamente controlada, todas elas, no 
pior caso, estarão sem comunicação com seus respectivos pilotos remotos. Deve-se considerar que uma aeronave com perda do controle remoto deve ser capaz de voar, navegar e comunicar com o controlador de voo. Apenas simplificar o procedimento de voo autônomo, para, por exemplo, uma rota de pouso automático, pode gerar a situação de perigo onde mais de uma aeronave em tal situação realizaria a manobra pré-definida de emergência sem levar em conta outras aeronaves tentando fazer a mesma manobra. Duas ou mais aeronaves em manobra automática de pouso podem seguir procedimento de manobra automática (sem critério de contexto) e colidirem entre si.

\subsection{O Sistema de Navegação Aérea}

Esta seção apresenta o sistema de navegação aérea, sua concepção segundo a $\mathrm{OACl}$, além de apresentar os meios de como ele é gerido. Com a definição de conceitos relacionados ao espaço aéreo, é possível contextualizar o VANT no Espaço Aéreo, em particular, o Espaço Aéreo Controlado e Não Segregado.

O Sistema de Gerenciamento de Tráfego Aéreo (Air Traffic Management ATM) baseia-se no fornecimento de serviços, e estes são resultantes da ação conjunta de todos os recursos, incluindo o espaço aéreo, os aeródromos (aeroportos), a infraestrutura tecnológica, as aeronaves e os recursos humanos, todos como parte integrante do ATM. A função primária do Sistema ATM é possibilitar o voo de um aeródromo a outro, em um determinado espaço aéreo, livre de perigos, obedecendo aos limites de capacidade do Sistema e fazendo uso de todos os seus recursos (DECEA, 2011).

O ATM é regido pelos seguintes Princípios:

a) Segurança Crítica Operacional - A garantia de um Sistema ATM operacionalmente seguro é a mais alta prioridade no gerenciamento de tráfego aéreo, de modo a possibilitar o alcance da eficiência desejada de voos, mantendo sempre os níveis de segurança requeridos;

b) Ser Humano - Os seres humanos desempenham uma função essencial e são o elemento central do Sistema. São os responsáveis por sua gestão, pelo monitoramento de seu desempenho e pela intervenção, 
quando necessário, de modo a assegurar os resultados desejados, sobretudo no que tange aos Controladores de Tráfego Aéreo;

c) Tecnologia - O Conceito Operacional ATM Global (ICAO, 2013) não faz referência a qualquer tipo de tecnologia específica, mas a escolha da tecnologia deve considerar as características da infraestrutura disponível;

d) Informação - A Comunidade ATM é diretamente dependente do recebimento de informações, as quais deverão ser processadas em tempo oportuno, ser relevantes, precisas, confiáveis e com qualidade assegurada, viabilizando o suporte necessário às ações colaborativas e orientadoras para as tomadas de decisões. $O$ amplo compartilhamento de informações relativas ao sistema permite que a Comunidade ATM conduza suas atividades e operações de forma segura, eficiente e com uma relação custo-benefício favorável;

e) Colaboração - O Sistema ATM é caracterizado por um planejamento integrado em nível estratégico e tático, através do qual os membros da Comunidade ATM participarão na definição dos vários tipos e níveis de serviços;

f) Continuidade - A realização prática do Conceito Operacional ATM Global requer o estabelecimento de medidas de contingência, de modo a garantir a máxima continuidade do serviço, em caso de interrupções causadas por fatores adversos, desastres naturais, agitação civil, ameaças à segurança, bem como outras circunstâncias eventuais; e

g) Integração civil e militar - As atividades desenvolvidas no Sistema ATM, no caso do cenário brasileiro, devem ser executadas aproveitando a infraestrutura aeronáutica militar em proveito das operações da aviação civil e militar, de modo a garantir a segurança, regularidade e eficiência da navegação aérea de forma econômica e integrada.

Este resumo de princípios que regem o ATM representa o desafio que os VANT devem atender a longo prazo. 


\subsubsection{Concepção Operacional ATM Global da OACI (ICAO Global ATM Operational Concept)}

A Concepção Operacional ATM Global (tradução adaptada de Global ATM Operational Concept) foi definida pela OACI e está descrita no documento OACI 9854 (ICAO, 2004) e é comumente referenciada apenas por Sistema ATM Global. O Conceito Operacional do Gerenciamento de Tráfego Aéreo Global apresenta o ponto de vista da OACI de um sistema ATM integrado, harmonizado e globalmente interligado.

Um sistema ATM Global pode ser descrito como um sistema mundial que, em uma base global, atinge a interoperabilidade e uniformidade entre as regiões para todos os usuários durante todas as fases do voo, atende aos níveis acordados de segurança; prevê operações econômicas otimizadas, é ambientalmente sustentável e principalmente atende aos requisitos de segurança nacional.

Com esta concepção operacional, a $\mathrm{OACl}$ procura definir uma estratégia que visa alcançar a curto e médio prazo, o Gerenciamento do Tráfego Aéreo (ATM) de forma a obter melhores benefícios a partir dos recursos disponíveis e futuros com base nas demandas futuras previstas na infraestrutura ATM. Essa concepção contém orientações sobre as melhorias necessárias no ATM para garantir uma transição uniforme para o sistema ATM, previsto no documento Global Air Traffic Management Operational Concept da OACI. O horizonte planejado para que o ATM Global seja atendido pelos Estados Membros subordinados à OACI tem etapas que vão até de 2028 (ICAO, 2013). Dado que, para os Estados Membros atenderem às exigências da $\mathrm{OACl}$, é necessário o uso de tecnologias disponíveis, o prazo do ano 2028 pode ser estendido conforme a necessidade.

Esse novo conceito operacional da $\mathrm{OACl}$ apresenta uma série de mudanças conceituais que irão evoluir ao longo das fases de implementação que os Estados Membros irão realizar, conforme os prazos pré-estabelecidos. A principal filosofia a ser adotada no novo conceito operacional é a noção de utilização do gerenciamento do uso global de informação e, com isso, permitir, 
de forma evolutiva, uma mudança significativa nos papéis de todos os participantes do ATM.

A premissa adotada pela OACI é a de que esta filosofia adotada irá facilitar as melhorias na segurança, economia e eficiência do sistema (ICAO, 2013). Esta filosofia é baseada, em grande parte, na evolução do processo de cooperação e colaboração de tomada de decisão global, na qual as expectativas divergentes e os interesses de todos os membros da comunidade envolvida (em escala internacional) são equilibrados para alcançar a equidade do gerenciamento de tráfego aéreo (ATM).

\subsubsection{Espaço Aéreo Controlado e Não Segregado}

O dever do Gerenciamento do Tráfego Aéreo (ATM) é garantir voos seguros, regulares e eficazes, respeitando as condições meteorológicas presentes, assim como as limitações operacionais da aeronave.

A prestação desse serviço no Brasil está baseada nas normas e nos métodos recomendados pela $\mathrm{OACl}$, de forma a garantir os mesmos níveis de segurança definidos internacionalmente para todas as aeronaves que utilizam o espaço aéreo Brasileiro.

No espaço aéreo, há uma variedade de atividades que ocorrem simultaneamente: voos civis, voos militares, voos de recreação, lançamentos de foguetes, entre outros.

Para garantir a segurança de todas essas atividades, os órgãos reguladores proveem a segmentação do espaço aéreo e, consequentemente, ações adequadas para cada segmento desse espaço. Exemplos de ações são a definição de aerovias, procedimentos de subida e descida, protocolos de comunicação, delimitação de áreas condicionadas e comando hierárquico do Controle de Tráfego Aéreo com as aeronaves.

O espaço aéreo pode ser dividido segundo quatro conceitos: Espaço Aéreo Não Segregado, Espaço Aéreo Controlado, Espaço Aéreo Não Controlado e Espaço Aéreo Condicionado, a seguir detalhados. 
O Espaço Aéreo Controlado é definido como espaço em que todos os movimentos aéreos são controlados por um órgão de tráfego aéreo, sendo que os pilotos são orientados a cumprir manobras pré-estabelecidas, com a missão de garantir a segurança dos voos compartilhando esse espaço. Esses espaços aéreos são estabelecidos como: Aerovias (AWY), Áreas de Controle (TMA) e Zonas de Controle (CTR). Para se utilizar o espaço aéreo controlado, é obrigatório o uso de permissões dos órgãos responsáveis por seu controle.

O Espaço Aéreo Não-Controlado é o espaço aéreo em que as aeronaves voam em ambiente parcialmente conhecido e sujeito às regras do ar. Porém, não existe a prestação do serviço de controle do tráfego aéreo. São fornecidos, somente, os serviços de informação de voo e de alerta.

O Espaço Aéreo Condicionado define ambientes onde são realizadas atividades específicas que não permitem a aplicação dos serviços de tráfego aéreo.

Espaço Aéreo Não Segregado é definido por um ambiente específico para a aeronave, a missão e o contexto que ela voará. Para o caso de VANT Autônomo controlado pelo SAP, deve-se considerar que o Controle de Tráfego Aéreo irá receber essa aeronave no mesmo espaço compartilhado pelas demais, ou seja, não segregando tal aeronave. Para considerar o VANT de forma não segregada no espaço aéreo, o Controle de Tráfego Aéreo tem de interagir com ele da mesma forma que interage com as demais aeronaves. Essa definição força o VANT a ter como requisito o desafio de ser transparente para os demais atores do espaço aéreo não segregado. Esse requisito define o grau de exigência em um futuro processo de certificação de um VANT por parte dos órgãos governamentais responsáveis.

Quando se considera que o VANT seja transparente para o controle de tráfego aéreo em um espaço aéreo não segregado, significa que o projetista do VANT deve considerar, além da missão a que o VANT se propõe, respeitar e possuir todos os recursos necessários para interagir com os serviços de tráfego aéreo. Resumidamente, esses serviços podem ser descritos por Voar, Navegar e Comunicar. Por Voar, entende-se a tarefa que um piloto (ou SAP) deve executar, garantindo que o avião esteja sob controle. Em seguida, deve-se 
garantir que a aeronave siga uma trajetória segura de navegação, pré-definida e livre de obstáculos. Tanto Voar como Navegar são dependentes de condições do espaço aéreo externo, tal como meteorologia. Apenas após os dois primeiros fatores estarem assegurados, a tripulação ou SAP deve se preocupar em se comunicar com os órgãos de controle da melhor maneira possível e obedecê-los conforme comandos recebidos (tais como mudança de nível de voo, alteração de rotas de aproximação de aeródromos, entre outros).

\subsubsection{O VANT e o ATM Global}

Observando o escopo do conceito operacional, pode-se observar também que o documento Concepção Operacional ATM Global também detalha como o ATM atuará diretamente nas trajetórias de voos de veículos tripulados e não tripulados durante todas as fases do voo e a interação de uma trajetória de voo com qualquer tipo de Perigo (Hazard). Conforme o documento de concepção operacional ATM Nacional do DECEA (DECEA, 2011), o termo Perigo (Hazard) apresentado no documento OACI 9854 é traduzido por Risco. Desta forma, no documento DCA-351-2 (DECEA, 2011), os Riscos considerados para uma aeronave são: outra aeronave, o terreno, a meteorologia, a esteira de turbulência, a atividade incompatível no espaço aéreo, os veículos na superfície e os outros obstáculos situados no pátio ou na área de manobras (ICAO, 2004).

Um VANT, portanto, deve estar sob a supervisão e regulamentação do ATM Global da mesma forma que as demais aeronaves tripuladas. O Documento OACl define que o VANT deve estar previsto como parte do Sistema ATM Global, porém, não define como o VANT deve ser inserido nesse sistema.

Considerando que não há um conjunto de procedimentos operacionais definidos para um VANT, que o documento de Concepção Operacional do ATM Global (ICAO, 2004) apresente um grau de generalidade muito alto, optou-se, nesta Tese, utilizar-se como referência normas e metodologias já existentes para aeronaves tripuladas. Esta escolha comportou o desenvolvimento de um processo que permita ao VANT ser avaliado do ponto de vista da segurança crítica. De posse de um método de avaliação da segurança crítica, é possível 
desenvolver processos de certificação de VANT para sua integração ao Sistema ATM Global.

O documento OACI 9854 considera que o VANT já deve estar previsto na evolução do sistema de tráfego aéreo. Nota-se, que esse documento define que o Gerenciamento de Tráfego Aéreo (ATM) deve considerar a trajetória de um veículo tripulado ou não tripulado durante todas as fases de voo. Define-se também que o ATM deve gerenciar a interação das trajetórias dessas aeronaves (tripuladas ou não) com outras trajetórias ou perigos, visando obter um resultado ótimo ao sistema ATM, com a necessidade de desvio mínimo das trajetórias de voos requeridas.

Uma citação explícita sobre o VANT é observada no item 2.6 do documento OACI 9854 (ICAO, 2004), (Airspace User Operations): "Both manned and unmanned aerial vehicles will form part of the ATM system. The ATM system will accommodate the limited ability of some vehicles to dynamically change trajectory". 


\section{MÉTOdOS DE AVALIAÇÃo DE SEGURANÇA CRÍTICA APLICADAS À AVIAÇÃO}

Os métodos de avaliação de segurança crítica são essenciais para o desenvolvimento de sistemas críticos. Muitas técnicas e métodos foram desenvolvidos para realizar o processo de avaliação de segurança de uma determinada operação, procedimento ou sistema.

Uma vez que tem havido uma grande evolução de métodos, em diferentes domínios, há uma dificuldade em localizá-los e utilizá-los para uso prático. Portanto, para muitas organizações há o desafio de encontrar as técnicas ou ferramentas que melhor se adaptem. O Instituto NLR (Nationaal Lucht- en Ruimtevaartlaboratorium) (EVERDIJ, BLOM, 2013), por meio de uma extensa literatura e pesquisa, complementada por entrevistas com especialistas de diferentes domínios, criou uma coleção de métodos de avaliação de segurança crítica em uma base de dados. Essa base de dados contempla, até o momento, 806 métodos identificados. Os métodos provêm de diversos domínios de aplicação, tais como a indústria da energia nuclear, aviação, telecomunicações e indústria de processo químico. Trabalho similar de compilação de métodos de avaliação de segurança crítica voltados para a aviação foi realizado pela rede Global Aviation Safety Network (GAIN, 2013), criada pela FAA, com o objetivo de incentivar a cooperação entre a indústria, governo e usuários visando o sistema global de aviação mais seguro.

Nesse cenário de falta de padronização de métodos, há a demanda de avaliar a segurança do VANT. A exigência emergente para operações não segregadas de VANT civis é nova, mas não regulamentada junto às operações civis tripuladas (ICAO, 2004). Em função desse cenário, esta Tese se baseou em Métodos Gerais de Certificação já utilizados pelas principais organizações da área. O VANT, em sua essência, constitui-se em um conjunto de programas (software) suportado por circuitos digitais (hardware) baseado em computadores, com o dever de avaliar suas entradas e garantir que suas ações colaborem com a missão de completar um voo, de modo seguro, realizando tarefas atualmente feitas por humanos. 
A norma IEC 61508 (Functional Safety of Electrical/Electronic/Programmable Electronic Safety-related Systems) tem a função de fornecer padrões de segurança no desenvolvimento de equipamentos (hardware) de um sistema com aplicação crítica (IEC, 1998). O desenvolvimento de software para a aviação, por exemplo, é baseado na norma RTCA DO-178C (RTCA, 2011). O desenvolvimento de software para a aviação civil é definido por normas e por procedimentos, tais como a necessidade de se ter um projeto aprovado em uma agência reguladora (ANAC ou FAA, por exemplo) antes mesmo de se desenvolver o software do projeto. Há, finalmente, a etapa de Avaliação de Segurança Crítica do Sistema (System Safety Assessment - SSA). Essa avaliação envolve os órgãos reguladores, que irão verificar o contexto geral do sistema.

Na modelagem de uma aeronave, tanto em um VANT, como em uma aeronave tripulada, há diversos equipamentos de software e há uma grande preocupação por parte de órgãos certificadores para garantir a segurança desses equipamentos. Nas aeronaves tripuladas, uma vez que a tomada de decisão é feita por um humano, não há a necessidade de definir normas específicas para a tomada de decisão automatizada. No caso de VANT, há um software verificando os dados dos equipamentos para a tomada de decisão, visando a garantia das regras de voo. Em função desta demanda, é feita uma apresentação do cenário mundial no que tange à normatização e regulamentação da aviação.

A integração do VANT no espaço aéreo controlado apresenta um conjunto de desafios que surgem em função de particularidades existentes nesta categoria de aeronave quando comparadas ao modo de operação de um voo tripulado regido pelo $\mathrm{ATM}$ atual. Na comunidade científica, ter o Gerenciamento de Tráfego Aéreo considerando o uso de VANT em um espaço aéreo em diferentes níveis de integração ainda é visto como uma nova área de pesquisa que carece de muito estudo (PAHSA et al, 2011).

Quando se avaliam as razões de se proibir a operação de VANT fora do espaço aéreo não segregado, compartilhando espaço com outras aeronaves tripuladas, a principal delas é a falta de histórico, tanto científico como 
estatístico, que demonstre que o VANT é tão seguro quanto uma aeronave tripulada. O fato de existir a dúvida, dado o grau de segurança exigido nesse setor, faz com que muitos dos órgãos reguladores envolvidos não permitam o uso comercial de VANT, mesmo em regiões de espaço aéreo não segregado.

Pode-se concluir, então, que o principal desafio existente no domínio dos VANT é garantir que uma aeronave não tripulada seja tão ou mais segura que uma aeronave tripulada voando sob as mesmas condições de voo, incluindo o mesmo espaço aéreo. Para tanto, todo o conjunto de envolvidos e interessados possui o desafio de demonstrar que a integração de uma aeronave não tripulada atende, pelo menos, os mesmos níveis de segurança crítica, confiabilidade, disponibilidade e desempenho exigidos pelos órgãos reguladores e que são devidamente atendidos pela aviação civil tripulada.

É importante ressaltar que este desafio não se restringe às limitações tecnológicas atuais para que se tenha o uso de VANT no espaço aéreo. Há, também, os aspectos sociais e, consequentemente, legais que devem ser estudados e apresentados para a sociedade que os utilizará ou que poderia ser afetada pelo seu uso, mesmo de forma indireta. É esperado, também, que a sociedade, em função da tolerância ao risco que ela está disposta a aceitar, exija que se prove que os VANT sejam mais seguros que as aeronaves tripuladas.

Além disso, a OACl definiu que o VANT não tem permissão para voar sem piloto remoto, pois não há provas de que ele voe do mesmo modo que um avião tripulado (ICAO, 2011), ou seja, que seu voo ocorra de forma segura e transparente perante o ATM que o supervisiona, sem distinção entre aeronaves tripuladas e não tripuladas. Independente desta proibição definida pela OACI, há a necessidade de redefinir as regras a que futuros VANT venham a estar submetidos em um espaço aéreo, seja este controlado, não controlado ou segregado ou não segregado. A necessidade de provas científicas e estatísticas (mostrando o histórico de segurança de tais aeronaves não tripuladas) é uma condição necessária para haver o desenvolvimento de Normas e Práticas Recomendadas (Standards and Recommended Practices - 
SARP) e, consequentemente, a regulamentação por parte dos órgãos responsáveis.

Grandes empresas do setor aeroviário demonstram que há uma demanda por VANT em aplicações civis. Organizações regulamentadoras, como FAA e Eurocontrol também têm demonstrado preocupações sobre como inseri-los no espaço aéreo. Pode-se observar esta preocupação ao avaliar o que as organizações internacionais têm feito a respeito do tema (CORREA, 2006):

- A Agência Europeia de Segurança da Aviação (European Aviation Safety Agency - EASA) tem desenvolvido critérios de navegabilidade aérea para a certificação de VANT;

- A Joint Aviation Authorities (JAA) e a Eurocontrol têm trabalhado de forma conjunta para formularem o modo operacional internacional (inicialmente com a abrangência europeia) para o VANT no espaço aéreo controlado;

- A Federal Aviation Agency (FAA) tem pesquisado meios de integrar, de maneira segura, o VANT no Sistema do Espaço Aéreo Nacional dos Estados Unidos da América (National Airspace System).

Neste sentido, é importante apresentar um conjunto de desafios para futuras definições de requisitos de segurança crítica e, consequentemente, permitir uma definição de normas para a integração do VANT no espaço aéreo controlado. As organizações internacionais responsáveis pela regulamentação do tráfego aéreo assumem esta abordagem de regularizar o uso de VANT sem se limitar a questões tecnológicas, mas há desafios ainda em aberto, conforme apresentado a seguir.

\subsection{Segurança Crítica na Aviação Tradicional}

A aviação tradicional, com aeronaves tripuladas, sem considerar o VANT em seu contexto, possui um alto rigor quanto ao nível de segurança crítica exigido. Este nível de segurança está associado diretamente com o risco aceitável pela sociedade mundial. Há riscos relacionados a perdas de vida, a mercado financeiro, a danos ambientais, dentre outros, porém em diversos aspectos, há uma convergência de técnicas adotadas para a avaliação dos Riscos 
envolvidos (SPITZER, 2006). Neste contexto, o risco é o de haver a possibilidade de uma aeronave violar a separação mínima, podendo acarretar perigos. Conforme definido pela OACI (ICAO, 2013), perigo pode ser representado por outra aeronave, pelo terreno, pela meteorologia, por uma esteira de turbulência, por uma atividade incompatível no espaço aéreo, por veículos na superfície e outros obstáculos situados no pátio ou na área de manobras.

Uma definição utilizada para a análise de risco é dada por algo ou alguém que pode causar algum dano ou perigo. Desta forma, deve-se providenciar respostas a problemas, como por exemplo, de que maneira a análise de risco deve ser conduzida, de quem deve ser a responsabilidade desta análise e, principalmente, o que deve ser, de fato, analisado. Porém, a quantificação do risco é baseada em valores de referência definidos e fornecidos pelas organizações responsáveis pela regulamentação do espaço aéreo, em destaque para a OACI. Resultados de pesquisa realizados por Clothier et al. (2007) recomendam que se tenha no máximo $1 \times 10^{-9}$ acidentes fatais com 0 solo por hora de voo para ser usado como referência para quantificar o risco de um VANT integrado no espaço aéreo não segregado.

\subsection{Os Desafios do VANT perante as Organizações Aeronáuticas}

A falta de histórico sobre o comportamento dos VANT (e possíveis acidentes) no espaço aéreo controlado pode ser entendida tanto pelo desenvolvimento bastante recente desses aparelhos no domínio civil, quanto pelo fato de o desenvolvimento de VANT ter tido origem em aplicações militares.

Na visão militar, a falta de regulamentação sobre os requisitos de preservação da aeronave ou riscos à população decorrentes de possíveis acidentes em território inimigo não são relevantes. Por outro lado, na aviação civil, a preservação da aeronave e o risco de acidentes envolvendo vítimas em solo são prioritários. Em uma investigação feita por Whitlock (2014), constatou-se que mais de 400 VANT militares americanos de grande porte caíram, envolvendo-se em acidentes graves em todo o mundo. 
A investigação de Craig de registros de acidentes de VANT mostra que mesmo os desenvolvedores de VANT militares ainda têm de superar alguns obstáculos fundamentais de segurança:

- Uma capacidade limitada para detectar e evitar problemas. Muitos VANT de pequeno porte, por exemplo, não estão equipados com radar ou sistemas contra colisão projetados para prevenção de desastres no ar;

- Erros do SAP e de Pilotos Remotos. Mesmo com pilotos habilitados e em constante treinamento, erros são ainda comuns. Durante a investigação de Whitlock, em quatro casos durante um período de três anos, pilotos da força aérea norte americana cometeram erros graves que levaram a uma investigação por suspeita de negligência do dever;

- Defeitos mecânicos inerentes. Muitos acidentes que ocorreram com VANT foram provocados por falhas simples; outros foram causados por condições climáticas. As tripulações de dois VANTS Predators que caíram em 2008 e 2009 foram investigados e a conclusão foi dada como inexplicável;

- Enlaces de comunicação confiável (para pilotos remotos). Os VANT controlados remotamente são dependentes de transmissões sem fio para transmissão de comandos e informações navegacionais, geralmente via satélite. Os registros de voo mostraram que os enlaces de comunicação eram frequentemente interrompidos.

Mesmo com complexos desafios, no domínio militar ou civil, tanto as organizações internacionais, como a comunidade científica estão em busca de respostas para a integração de VANT no espaço aéreo não segregado. Para exemplificar, a EASA está desenvolvendo critérios específicos de navegabilidade aérea, de forma a certificar os VANT (EASA, 2008). A JAA, em parceria com a Eurocontrol está trabalhando para especificar os meios de se operar internacionalmente o VANT no espaço aéreo controlado (JAA, 2004).

Para tanto, a JAA e a Eurocontrol têm abordado o uso de VANT em espaço aéreo segregado (área restrita) como uma solução viável. A solução de operar esse tipo de aeronave apenas em espaço aéreo segregado (áreas restritas) 
não exclui o risco que ela representa à sociedade que está em solo sob o espaço aéreo segregado, forçando assim, que sejam pesquisadas novas soluções mais abrangentes. A FAA também tem trabalhado em um processo independente para a integração segura dos VANT em seu Sistema de Navegação Aérea (National Airspace System - NAS) (DALAMAGKIDIS; VALAVANIS; PIEGL, 2012, p. 137). Da mesma forma que a JAA, a FAA também tem abordado somente 0 voo em espaço aéreo segregado, particularmente para pequenos VANT focados para o uso no espaço aéreo entre a fronteira dos Estados Unidos com o México (FAA, 2015), apresentando uma postura conservadora diante dos problemas de incertezas.

A lista a seguir apresenta os aspectos que a OACI tem considerado como sendo os mais relevantes ao domínio do VANT, fornecendo um indicativo para as organizações certificadoras, de forma a se obter uma convergência na integração de VANT no espaço aéreo não segregado (ICAO, 2011) (lista esta relacionada ao conjunto de 18 anexos definidos na Convention on International Civil Aviation da OACI):

a. Licenciamento (descrito no documento Anexo 1 da OACI) (ICAO, 2001a);

b. Regras do Ar (descrito no documento Anexo 2 da OACI) (ICAO, 1990);

c. Operação da Aeronave (descrito no documento Anexo 6 da $\mathrm{OACl}$ ) (ICAO, 2001b);

d. Aeronavegação da Aeronave (descrito no documento Anexo 8 da $\mathrm{OACl}$ ) (ICAO, 2001c);

e. Telecomunicações Aeronáuticas (descrito no documento Anexo 10 da OACI) (ICAO, 1996);

f. Segurança - Protegendo a Aviação Civil Internacional contra atos de Interferência llegais (descrito no documento Anexo 17 da OACI) (ICAO, 1997).

Esta lista de aspectos mais relevantes apresentados pela OACl em (ICAO, 2011), apesar de estar reduzida em relação a todos os anexos existentes, ainda é bastante abrangente, denotando o grau de dificuldade apresentado por 
esse desafio de integração de VANT no espaço aéreo (mesmo quando se trata do espaço aéreo segregado).

Em particular, pode-se observar que a comunicação com elementos externos será um fator de importância, que permitirá a operação segura de VANT. Isto porque, na visão da OACI (ICAO, 2011), em um primeiro momento, todos os VANT devem ser remotamente controlados. Desta forma, em particular o item 'e', torna-se crítico e necessita estar claramente definido para que a identificação e proteção de frequências de controle da aeronave sejam gerenciadas em função de bases internacionais, permitindo que o VANT possa ter seu potencial comercial desenvolvido. Isto significa que o VANT necessitará de uma alocação significativa de banda de frequências para a coordenação arsolo. Nota-se, então, o grande desafio de alinhavar os interesses de coordenação e liberação de espectro de frequências entre os países membros da $\mathrm{OACl}$ e, consequentemente, suas respectivas leis nacionais relacionadas às tecnologias (ainda em desenvolvimento) do VANT.

De forma geral, até o momento não há padronização internacional que permita o uso de VANT em um espaço aéreo controlado. Os processos de certificação de sistemas aviônicos, apesar de estarem consolidados para a aviação tripulada, não estão definidos para os novos sistemas aviônicos específicos para o VANT. Tem-se uma visão do grau de dificuldade existente, dada a quantidade de atores envolvidos na geração de um caminho para a padronização e uniformização dos elementos necessários para o voo seguro de VANT, pois, até o momento, os riscos que a aeronave apresenta ainda não estão plenamente mapeados.

Instituições independentes deverão estudar a própria forma de lidar com as mudanças culturais geradas pelo uso de VANT, de maneira a atender os mesmos princípios de segurança aplicados às aeronaves tripuladas. Não há comprovação científica que valide a taxa de acidentes por hora de voo, utilizada para a aviação civil comercial, como sendo suficiente para habilitar o uso de VANT no domínio civil. Uma vez que o risco de acidentes existente para uma aeronave, em um espaço aéreo compartilhado, ocorre quando outra aeronave invade sua zona de proteção, há o desafio de formalizar e, 
principalmente, mensurar o risco existente de os veículos não tripulados violarem tais zonas de proteção.

Para atingir os níveis de segurança atuais da aviação civil comercial, os VANT devem estar em conformidade com As Normas e Práticas Recomendadas (Standards and Recommended Practices - SARPS) definidas pela OACI que são aplicadas a todas as aeronaves tripuladas. Não há, porém, SARPS específicas para VANT integrado no espaço aéreo controlado e não segregado. A OACI concorda que há a necessidade de haver SARPS específicas, porém, há uma expectativa de que tais SARPS surjam da experiência e de definições dos países interessados, antes de ela própria expor suas SARPS sem uma harmonização internacional prévia. (ICAO, 2011).

Do ponto de vista da aviação civil para VANT, a falta de normatização por parte da $\mathrm{OACl}$, tem implicado um atraso no desenvolvimento de regras nacionais a respeito. Como a operação civil de VANT não está presente em nenhuma das SARPS da OACI, mas somente na Circular 328 (ICAO, 2011), também da $\mathrm{OACl}$, há a expectativa, por parte da comunidade aérea, de que haja adendos às SARPS atuais para formalizar a operação civil, assim como o licenciamento de pilotos que precisem pilotar remotamente os VANT.

Ao se observar o conjunto de Anexos e SARPS da OACI referentes à navegabilidade aérea, há uma grande massa de dados que podem ser utilizados, visando uma possível certificação de VANT, porém, um estudo detalhado que vise a agregação de todo esse conhecimento aplicado aos VANT ainda se encontra em aberto. Um estudo desta natureza deve prover dados que mostrem o que é válido e o que deve ser gerado de novo para a certificação da navegabilidade aérea dos VANT. Para tanto, espera-se que instituições de pesquisa e órgãos responsáveis, como a OACI, FAA e Eurocontrol realizem avaliações de segurança, de forma que os Estados Membros possam confiar nas recomendações que irão surgir.

Particularmente, ao se tratar da inclusão de um VANT em um espaço aéreo controlado, o Anexo 2 da OACI, Rules of the Air (ICAO, 1990), requer um maior esforço da comunidade envolvida para se definir a total compatibilidade entre aeronaves com e sem tripulação a bordo. É importante ressaltar que um 
desafio que surge em relação ao Anexo 2 é relativo aos parâmetros perceber $e$ evitar (sense and avoid) para VANT, especificamente em relação às distâncias mínimas em que eles devem manter de outras aeronaves.

Ainda será necessária uma convergência de normatização embasada internacionalmente para se garantir que não haja limitações de operações civis com VANT trafegando entre países. É importante considerar, porém que, assim como o desenvolvimento de uma nova tecnologia para a aviação tradicional tripulada, o desenvolvimento do mercado de VANT não pode requerer que as definições de ATM existentes sejam alteradas e remanejadas para que elas se adaptem à realidade que o VANT necessita.

Esta expectativa pode gerar um impasse, uma vez que a aviação civil atual está consolidada e, além dos parâmetros críticos de segurança crítica, há também os fatores econômicos. Para refletir esta linha de pensamento, a OACI tem apresentado 0 argumento que demonstra que o VANT deve estar preparado e adaptado ao ATM, e não o inverso (ICAO, 2011).

Está estabelecido na Circular 328 (ICAO, 2011) que a OACl não irá definir regras específicas sobre este assunto enquanto não houver um melhor domínio do problema, uma vez que ela cita que a aviação civil com o uso de VANT necessita de informações para conhecimento do comportamento das aeronaves não tripuladas, particularidades relativas à possibilidade de serem realizados voos com este tipo de aeronave.

A aviação civil tripulada está internacionalmente padronizada a partir de um histórico de voos de mais de cem anos, em que cada acidente investigado colaborou para se evitar novos acidentes de mesma natureza. O uso dos VANT, não irá implicar que a aviação, da forma como já está consolidada, irá se sujeitar ou tolerar uma sequência de acidentes a serem investigados para, posteriormente, aprimorar a segurança dos VANT. Pode-se concluir que os atuais e futuros VANT devem se adaptar às regras da aviação civil em espaço aéreo controlado e deverão provar sua capacidade de voar seguramente. 


\subsection{A Segurança Crítica na Aviação Civil e na Eurocontrol}

A Eurocontrol, em função de sua natureza multinacional, e com o objetivo de integrar um mesmo espaço aéreo europeu pertencente a diferentes nações, possui o dever de definir normas, requisitos e metodologias de avaliação da segurança crítica da aviação.

A missão da Eurocontrol é a de integrar os serviços de navegação aérea na Europa, focando a criação de um sistema de Gerenciamento de Tráfego Aéreo (ATM) uniforme e seguro, tanto para a aviação civil, como militar. Desta forma, os materiais preparados pela Eurocontrol têm a característica de serem abrangentes e independentes de tecnologia, apesar de terem o objetivo de seguirem as diretrizes definidas pela $\mathrm{OACl}$. Pode-se observar na documentação da Eurocontrol que ela não tem o objetivo de definir Normas, mas meios que levem a execução das diretrizes e aos níveis de segurança crítica definidos pela $\mathrm{OACl}$. Na comunidade europeia, a responsável por definir normas é a Agência Europeia para a Segurança da Aviação (EASA). A EASA constitui a base principal da estratégia da União Europeia em matéria de segurança crítica da aviação.

\subsubsection{Política de Segurança Crítica da Eurocontrol}

O objetivo geral de segurança crítica da Eurocontrol para o gerenciamento de tráfego aéreo (ATM) que seus Estados membros, sob as diretrizes da EASA, devem respeitar é (EASA, 2004): melhorar os níveis de segurança crítica, garantindo que o número de acidentes induzidos pelo ATM e incidentes potencialmente sérios ou de alto risco não aumente e, quando for possível, diminua. A partir deste requisito geral de segurança, a Eurocontrol define uma Política de Segurança Crítica como linha base para a abordagem básica para o gerenciamento da segurança crítica. Esta Política de Segurança Crítica é resumida conforme os tópicos principais descritos a seguir.

- Gerenciamento da Segurança Crítica: Os Prestadores de Serviços participantes do espaço aéreo europeu devem adotar uma abordagem formal, explícita e proativa de gestão da segurança nos serviços de navegação aérea. 
Como objetivo principal, um compromisso da alta gerência desses prestadores de serviços deve ser o de garantir elevados padrões de segurança, ou seja, a cultura de segurança deve estar presente desde o topo do organograma de um prestador de serviço. Dessa forma, uma abordagem intuitiva não pode ser considerada suficiente e as questões de segurança crítica devem ser tratadas e geridas de forma explícita.

- Implementação do Gerenciamento da Segurança Crítica: O Gerenciamento da Segurança Crítica deve ser implementada em todos os níveis da organização. Com isto, a Eurocontrol exige: Uma declaração formal da Política de Segurança da organização; A documentação do Sistema de Gerenciamento de Segurança Crítica e uma estrutura organizacional que apoie a implementação da política de segurança; e Meios para dar garantias sobre a eficácia da aplicação do gerenciamento de segurança crítica em cada unidade da organização.

Pode-se entender que estas exigências da Eurocontrol são condições prévias mínimas para o gerenciamento eficaz da segurança crítica. Estes aspectos são interdependentes e uma fraqueza em qualquer um deles irá comprometer a integridade do gerenciamento global da segurança crítica da organização em questão.

\subsubsection{Responsabilidade pela Segurança Crítica}

A Eurocontrol define que todos os envolvidos em projetos de sistemas aviônicos têm uma responsabilidade individual por suas próprias ações e os gestores são responsáveis pelo desempenho da segurança crítica de suas organizações.

A gestão da segurança do sistema depende de atribuição de responsabilidades individuais na organização. A obtenção de uma segurança satisfatória requer o compromisso e a participação de todos os membros da organização enquanto que a responsabilidade pela gestão da segurança pertence ao topo do organograma da organização. Isto significa que todos devem estar cientes das consequências de seus erros e se esforçar para evitá-los, podendo ser responsabilizados, mesmo que individualmente, por uma falha na segurança que venha a ocorrer. Assim, a gestão da segurança é a responsável por 
promover essa motivação básica para que todos desenvolvam uma consciência de segurança.

\subsubsection{Prioridade da Segurança Crítica}

A implementação de uma segurança satisfatória nos serviços de navegação aérea deve ter a mais alta prioridade em relação às pressões comercial, operacional, ambiental ou social.

A abordagem de Gerenciamento de Segurança Crítica deve incluir a natureza de tais pressões externas, que podem vir a gerar riscos para a segurança do tráfego aéreo como um todo.

\subsubsection{Objetivo de Segurança Crítica dos Serviços de Navegação Aérea}

Embora os Serviços de Navegação Aérea proporcionem um serviço importante para a sociedade, o principal objetivo da segurança crítica é minimizar a contribuição destes serviços de navegação aérea para o risco de um acidente aéreo tanto quanto possível.

Esta é a declaração de política fundamental, que define o que de fato deve ser alcançado. Deve-se notar que a Eurocontrol deixa claro que existem riscos e não há como garantir a segurança de maneira absoluta. "Tanto quanto possível" significa que os riscos devem ser equilibrados ao longo do tempo, os problemas inesperados, os custos e a dificuldade de tomar medidas para evitálos, considerando a probabilidade e gravidade de possíveis acidentes. Está implícito, portanto, que os riscos têm de ser identificados e quantificados antes de se definir quanto destes riscos a sociedade irá tolerar. Pode-se concluir, portanto, que a avaliação de riscos requer uma abordagem da aviação total, considerando todos os impactos no sistema de segurança global da aviação.

\subsubsection{Requisitos Regulatórios de Segurança da Eurocontrol}

Sob o controle da Eurocontrol, foi criada a Comissão de Regulamentação de Segurança Crítica (Safety Regulation Commission - SRC) como um organismo independente com o dever de emitir pareceres, a fim de garantir a coerência entre os níveis de segurança no gerenciamento do tráfego aéreo (ATM) do espaço aéreo europeu. A SRC é responsável pelo desenvolvimento de requisitos de segurança harmonizados para a regulamentação do sistema 
ATM, chamados de Requisitos Regulatórios de Segurança Crítica (Eurocontrol Safety Regulatory Requirements - ESARR), para serem aplicados pelas partes sujeitas à Eurocontrol. Estes requisitos necessitam serem aprovados pela Comissão Permanente da Eurocontrol. A SRC é responsável pelo desenvolvimento e a execução uniforme dos requisitos e objetivos regulatórios de segurança crítica para o ATM europeu, com o objetivo de garantir o desempenho da segurança crítica. A SRC é composta por representantes de organizações responsáveis pela regulamentação da segurança crítica do ATM a nível nacional.

Os Requisitos Regulatórios de Segurança da Eurocontrol (ESARR) foram formulados com o objetivo de definirem e padronizarem um conjunto de requisitos regulatórios de segurança para a implementação do ATM Global aos Estados Membros da Eurocontrol. (EUROCONTROL, 2009).

Com base neste conceito de serem generalistas, o desenvolvimento dos requisitos necessários para a integração de VANT no Espaço Aéreo Controlado e Não Segregado também serão desenvolvidos nesta Tese de maneira generalista, independente de tecnologia necessária.

\subsection{Metodologia de Avaliação de Segurança (Safety Assessment Methodology - E-SAM) da Eurocontrol}

Ao se estudar as normas utilizadas para a certificação de sistemas de aplicações de segurança crítica, é importante ressaltar que elas não levam em conta o grau de automação ou tecnologias específicas.

Portanto, tais normas devem ser aplicáveis para equipamentos (hardware e software) que estejam embarcados em um VANT da mesma forma que seriam aplicadas a uma aeronave tripulada. Isto reforça a Tese de que é necessário o desenvolvimento de normas e metodologias de avaliação de segurança crítica específicas para VANT no nível lógico, uma vez que, independente do tipo de controle que uma aeronave tenha, todos os aviônicos devem ser confiáveis e seguros (OLIVEIRA; GIMENES; ALMEIDA, 2009). 
A norma de segurança SAE ARP4761 descreve as técnicas de engenharia de segurança crítica de sistemas de aviação, e, portanto, como já citado, é frequentemente utilizada em associação com a SAE ARP4754 (SAE, 2010).

Em resumo, a SAE ARP4761 avalia o ciclo de vida de segurança crítica, sendo que este é dividido nas seguintes etapas, todas integradas com o ciclo de vida de engenharia do sistema em desenvolvimento:

- Análise Funcional de Perigo (Functional Hazard Analysis - FHA): aborda a identificação de risco e análise preliminar de perigo, sem avaliação nessa etapa;

- Avaliação Preliminar de Segurança Crítica do Sistema (Preliminary System Safety Assessment - PSSA): consiste em uma análise da contribuição e interação dos subsistemas para os perigos do sistema;

- Avaliação de Segurança Crítica do Sistema (System Safety Assessment - SSA): avalia os resultados desde a concepção até e execução, assegurando que todos os requisitos de segurança são atendidos.

A norma recomenda a utilização de diferentes técnicas, aplicadas em uma ou mais etapas citadas. Em destaque, podem-se enfatizar as seguintes técnicas: Análise de Árvore de Falhas (Fault Tree Analysis - FTA), Análise por Modelo de Markov, Análise de Modo e Efeito de Falha (Failure Model and Effect Analysis - FMEA), entre outros.

Para facilitar seu entendimento, da mesma forma que ocorre com a IEC-61508, a norma apresenta um extenso exemplo de como ela deve ser aplicada, facilitando o entendimento de como as conhecidas técnicas de análise e avaliação de segurança são aplicados, conforme a etapa do projeto.

A Eurocontrol SAM (E-SAM) foi elaborada com base na SAE ARP 4761 que descreve várias técnicas para a análise de segurança de equipamentos $\mathrm{e}$ sistemas de aeronaves para aviação civil e é aplicada em conjunto com a SAE ARP 4754. SAE ARP 4754, por sua vez, foi desenvolvida no contexto da regulamentação norte-americana da FAR (Federal Aviation Regulations) e da JAR (Joint Airworthiness Requirements) (EUROCONTROL, 2006a). Porém, a adaptação é necessária, pois a metodologia necessita refletir o contexto em 
que ela é aplicada e incorporar as especificidades da abordagem proposta para o Sistema de Navegação Aérea. A Eurocontrol SAM está estruturada nas etapas citadas anteriormente: FHA, PSSA e SSA.

A Metodologia de Avaliação de Segurança Crítica (Safety Assessment Methodology - SAM) para o Sistema de Navegação Aérea (Air Navigation System - ANS) foi desenvolvida para agrupar e representar as melhores práticas de avaliação da segurança crítica para o Sistema de Navegação Aérea. Através da E-SAM, a Eurocontrol oferece um guia para a aplicação da avaliação de Segurança no Sistema de Navegação Aérea (EUROCONTROL, 2006a).

O escopo desta metodologia envolve os Sistemas de Navegação Aérea considerando os três tipos de elementos do sistema: pessoas, equipamentos e procedimentos e, consequentemente, suas interações (interna e externamente ao sistema) em um ambiente específico de operação.

A E-SAM procura, principalmente, permitir demonstrar que a segurança crítica está sendo gerenciada dentro dos níveis mínimos definidos e aprovados pelas autoridades competentes (chamados de Riscos Aceitáveis) com o objetivo de garantir esses níveis para todo o Sistema de Navegação Aérea. Esta metodologia é considerada pela Eurocontrol como uma metodologia bem estabelecida, dedicada e com as melhores práticas de avaliação de segurança crítica para o ANS.

Além disso, em relação à integração de componentes de bordo e de terra baseados no Sistema de Navegação Aérea, a Eurocontrol afirma que a E-SAM, implementa a abordagem de considerar o sistema de aviação como um todo, visando a avaliação da nova geração de Sistemas de Navegação Aérea. Além disso, a Eurocontrol prevê a revisão periódica do material, a fim de incorporar as melhorias necessárias.

Em função do perfil multinacional da Eurocontrol, o uso da E-SAM torna-se uma referência mais generalista e menos limitada às particularidades de um determinado país, permitindo que o uso dessa metodologia nesta Tese viabilize a formalização do método proposto para a avaliação da inclusão de VANT no espaço aéreo controlado e não segregado. 
Para que a aplicação Eurocontrol SAM seja eficaz, é necessário identificar e gerir numerosas interações entre processos de diferentes tipos de sistemas envolvidos no gerenciamento de tráfego aéreo. Na maioria dos casos, a saída de um processo resultará diretamente na entrada do processo seguinte.

Ao se estudar a documentação dos requisitos regulatórios da Eurocontrol (ESARR), conclui-se que, por não haver uma explicação de como a segurança é avaliada, a Eurocontrol precisou desenvolver uma metodologia. Esta metodologia, apesar de ser uma metodologia de avaliação de segurança, também não entra no mérito de como a segurança será feita, mas sim, tem o objetivo de ser uma guia para que a segurança seja avaliada.

A Eurocontrol SAM é uma metodologia de certificação de segurança crítica para o Sistema de Navegação Aéreo e foi desenvolvida com o objetivo de identificar as melhores práticas para obter-se esta certificação e servir de guia para sua aplicação (EUROCONTROL, 2006a).

Como primeira etapa na formação de um processo de certificação para VANT, é necessário definir quais fatores devem ser avaliados. A Eurocontrol SAM descreve um processo genérico que consiste de três passos principais na identificação destes fatores. Nesta seção, a E-SAM é apresentada de forma a embasar a proposta apresentada no capítulo 4. Essencialmente, a metodologia E-SAM descreve um processo genérico para a avaliação da segurança crítica do Sistema de Navegação Aérea, no qual este processo consiste em três principais passos:

- Avaliação Funcional de Perigo (Functional Hazard Assessment - FHA);

A FHA é um processo iterativo top-down, que deve ser feito no início do desenvolvimento ou modificação de um sistema de navegação aérea. $O$ objetivo do processo de FHA é determinar quão seguro o sistema deve ser. O pré-requisito para realizar e obter o FHA é possuir um descritivo em alto nível das funções do sistema, descrito no documento de conceito operacional (EUROCONTROL, 2006b). 
- Avaliação Preliminar de Segurança do Sistema (Preliminary System Safety Assessment-PSSA);

Assim como a FHA, a PSSA também é um processo interativo que deve ser feito no início do desenvolvimento ou modificação de um sistema de navegação aérea. A PSSA tem o objetivo de demonstrar se a arquitetura de sistema que está sendo avaliada pode atingir os objetivos de segurança crítica especificados na FHA. (EUROCONTROL, 2006c).

- Avaliação de Segurança do Sistema (System Safety Assessment - SSA)

A SSA é um processo com o objetivo de demonstrar que o sistema implementado atinge um risco aceitável e consequentemente, satisfaz os objetivos de segurança especificados na FHA, assim como se os elementos do sistema atendem os requisitos de segurança que devem ser especificados na PSSA (EUROCONTROL, 2006d).

A Figura 3.1 apresenta como se relacionam os processos de certificação no ciclo de vida do sistema. O FHA atua na definição do sistema e questiona o quão seguro o sistema precisa ser para alcançar um risco aceitável. O segundo passo, o PSSA, atua no projeto do sistema e questiona se a arquitetura que está sendo proposta é capaz de alcançar um risco aceitável. O SSA é o último nível e tem relação com a implementação e integração do sistema, nele surge a questão se o que está sendo implementado alcança um risco aceitável. Em todas as fases a segurança crítica é analisada e busca-se minimizar a distância do nível de segurança crítica que foi requisitado para o nível realmente implementado. 
Figura 3.1 - Relacionamento entre o Processo de Certificação de Segurança Crítica e o ciclo de vida completo do sistema

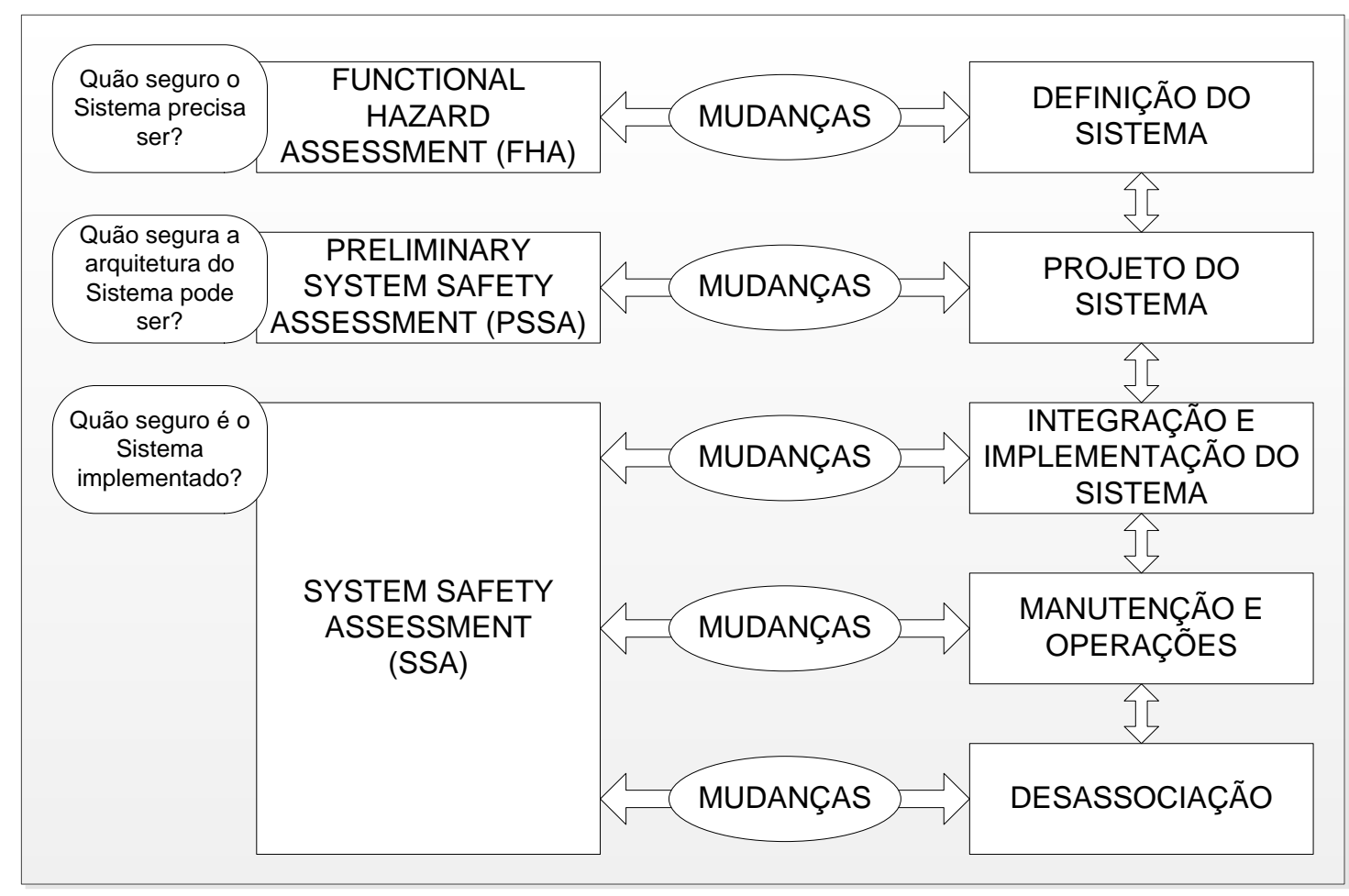

Fonte: Eurocontrol (2006a)

\subsubsection{O Processo Functional Hazard Assessment (FHA)}

O FHA (EUROCONTROL, 2006b) é um processo iterativo que deve ser aplicado no início do desenvolvimento de um sistema de navegação aérea. Nesta fase é que se determina qual o nível de segurança que o sistema precisa ter. Aqui são identificados os potenciais modos de falhas e danos.

A condução do FHA acontece justamente no momento do ciclo de vida em que o sistema está sendo definido e os objetivos de segurança crítica a serem alcançados devem ser anunciados.

Para cada função ou combinação de funções do sistema é preciso:

1. Identificar os danos em potencial: o que poderia dar errado com o sistema e o que poderia ocorrer se isto acontecesse;

2. Identificar os efeitos dos danos: como a segurança das operações de controle e da aeronave é afetada;

3. Certificar a severidade dos efeitos dos danos: quão severos seriam esses efeitos; 
4. Especificar os objetivos da segurança: qual frequência pode ser aceitável à ocorrência do dano;

5. Certificar o risco agregado pretendido: qual é o nível de segurança previsto?

Após a realização da $\mathrm{FHA}$, deve-se então fazer a primeira interação e avaliação de segurança do sistema por meio da PSSA.

\subsubsection{O Processo Preliminary System Safety Assessment (PSSA)}

O PSSA (EUROCONTROL, 2006c) é um processo iterativo aplicado no início de um novo projeto de um sistema de navegação aérea ou na modificação de um existente. O objetivo de desenvolver um PSSA é demonstrar se a arquitetura do sistema certificada alcança os objetivos de segurança crítica especificados no FHA.

Como mostra a Figura 3.2, o processo PSSA transforma os objetivos de segurança crítica em requisitos de segurança crítica alocados aos elementos do sistema, ou seja, especifica o nível de risco a ser alcançado pelos elementos do sistema. O PSSA também identifica um nível de certificação por elemento.

O propósito do PSSA é identificar o impacto de uma mudança na arquitetura e garantir a capacidade da nova arquitetura de encontrar os mesmos ou novos objetivos de segurança crítica. $O$ pré-requisito essencial para conduzir um PSSA é uma descrição das funções de alto nível do sistema, com uma lista de premissas, danos e seus objetivos de segurança associados. A lista de danos e objetivos de segurança vem do FHA e é completada durante o PSSA. 
Figura 3.2 - Papel do PSSA

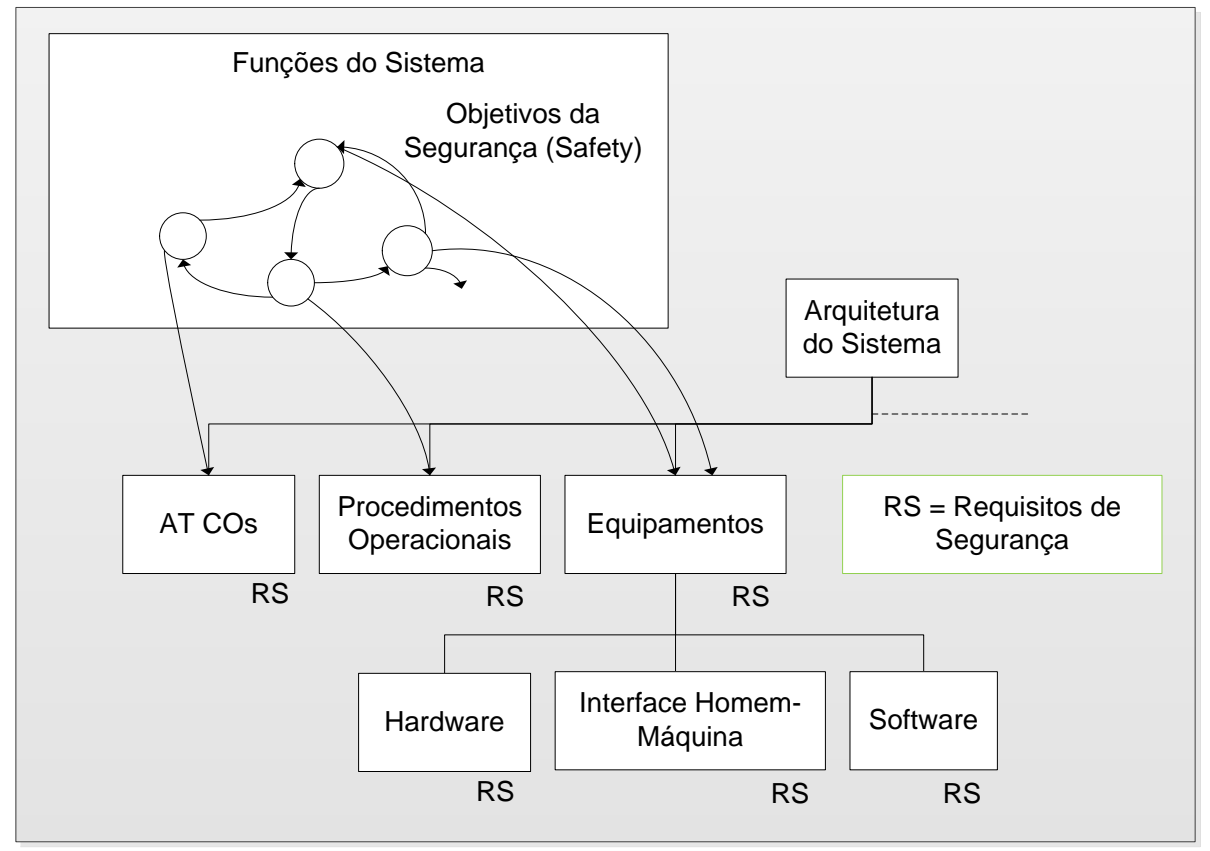

Fonte: Eurocontrol (2006c)

\subsubsection{O Processo System Safety Assessment (SSA)}

O SSA é um processo aplicado no início da implementação de um sistema de navegação aérea (EUROCONTROL, 2006d). O objetivo do SSA é demonstrar que o sistema encontre um risco aceitável e satisfaça seus objetivos de segurança crítica no FHA e os elementos do sistema encontrem seus requisitos de segurança crítica especificados no PSSA. O SSA monitora o desempenho do sistema durante seu tempo de vida operacional.

Figura 3.3 - Papel do SSA

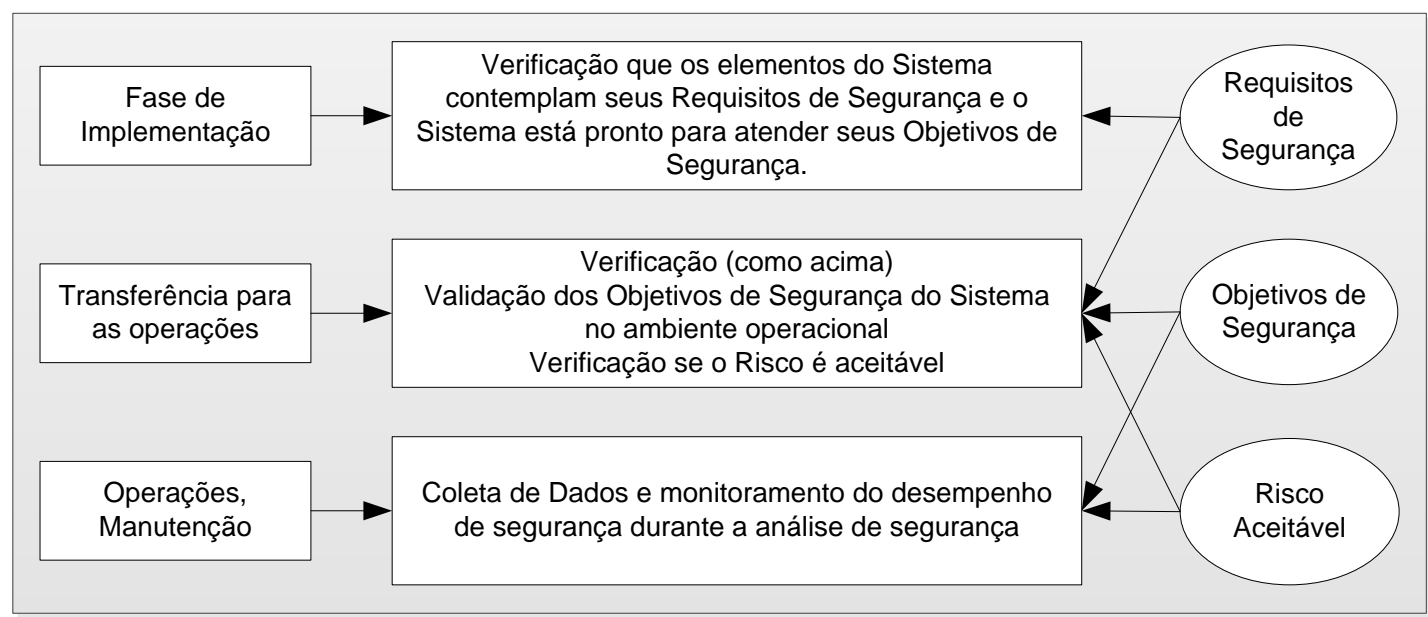

Fonte: Eurocontrol (2006d) 
O SSA, conforme apresentado na Figura 3.3, é conduzido durante as fases de implementação e integração do sistema, transferência em operação, operação, manutenção e entrega do ciclo de vida do sistema. Seu objetivo é limitar o número de iterações entre as atividades de desenvolvimento do sistema e a certificação da segurança crítica. $O$ desenvolvimento e certificação da segurança geralmente acontecem em paralelo.

O SSA integra os resultados das várias análises para verificar a segurança crítica do sistema como um todo e para cobrir todas as considerações de segurança crítica identificadas no PSSA. O processo de certificação inclui as seguintes informações:

a) Lista das probabilidades de eventos externos levantados previamente;

b) Descrição dos sistemas;

c) Lista das condições de falha (FHA, PSSA);

d) Classificação da condição de falha (FHA, PSSA);

e) Análise qualitativa para as condições de falha;

f) Análise quantitativa para as condições de falha;

g) Análise de causa comum;

h) Tarefas relacionadas à segurança crítica;

i) Níveis de garantia do desenvolvimento para hardware e software (PSSA);

j) Verificação que os requisitos de segurança vindos do PSSA estão incorporados no projeto e no processo de teste;

k) Os resultados do processo de verificação não analítico (ou seja, teste, demonstração e atividades de inspeção).

A aplicação da Eurocontrol SAM permite, então, ter uma visão sistêmica do projeto em desenvolvimento, seus riscos associados e sua capacidade de lidar com tais riscos.

\subsection{Escala de Avaliação de Qualidade de Manuseio Cooper Harper}

A Escala de Avaliação de Qualidade de Manuseio Cooper Harper é apresentada nesta seção para, posteriormente, no capítulo 4, ser adaptada 
para a avaliação de VANT. O pesquisador da NASA George Cooper apresentou a escala citada nesta seção, em 1957, designada por Escala de Classificação Cooper de Opinião do Piloto (Cooper Pilot Opinion Rating Scale), tendo como objetivo a tentativa de quantificar o desempenho da tarefa de carga de trabalho afetado como piloto (COOPER, 1957). Após novos estudos, Robert Harper fez uma parceria com Cooper para modificar a escala original de forma a abordar as características de movimentação de uma aeronave. Criaram, assim, a Escala de Avaliação de Qualidade do Manuseio de Aeronaves Cooper Harper (Cooper Harper Handling Qualities Rating Scheme) (HARPER; COOPER, 1986), designada aqui por Escala Cooper Harper.

O algoritmo que a Escala Cooper Harper adota é apresentado na Figura 3.4. Este algoritmo permite os pilotos avaliarem a qualidade de manuseio de uma aeronave em função da carga de trabalho envolvida, a capacidade de controle da mesma e a habilidade em manter um desempenho de voo adequado. Seguindo o fluxo do algoritmo, o piloto (especialista envolvido na avaliação) faz sua escolha que descreve as características da aeronave que melhor representa sua experiência de manuseio. Após a seleção feita, há uma quantificação na escala que vai de 1 a 10, que representa, na visão do piloto especialista, quão controlável é a aeronave e quanto seu desempenho é afetado pela aeronave. Os números quantitativos da escala, que estão associados com descrições específicas de características de manuseio, podem ser estatisticamente analisados para determinar a aptidão média de movimentação de aeronaves.

Assim, a escala original de Cooper Harper serve como uma ferramenta valiosa para a avaliação de manuseio de aeronaves (COTTING, 2011). A escala Cooper Harper ainda é utilizada para medir o desempenho de aeronaves (TAN et al., 2014) (MALPICA, 2015). No campo científico de VANT, a Escala Cooper Harper tem se tornado uma fonte valiosa de avaliação de algoritmos de controle de aeronaves (BAILEY, 2009; MALPICA, 2015).

No algoritmo da Escala Cooper Harper apresentado na Figura 3.4 as respostas do piloto sob avaliação o levam para uma série de escolhas que irão direcionálo a uma escolha de, no máximo, uma entre três classificações. Estas decisões 
são às vezes diretas e simples, em outros momentos difíceis. Elas são, no entanto, as decisões fundamentais para a realização de avaliações significativas, confiáveis e repetíveis.

Figura 3.4 - Algoritmo da Escala Cooper Harper

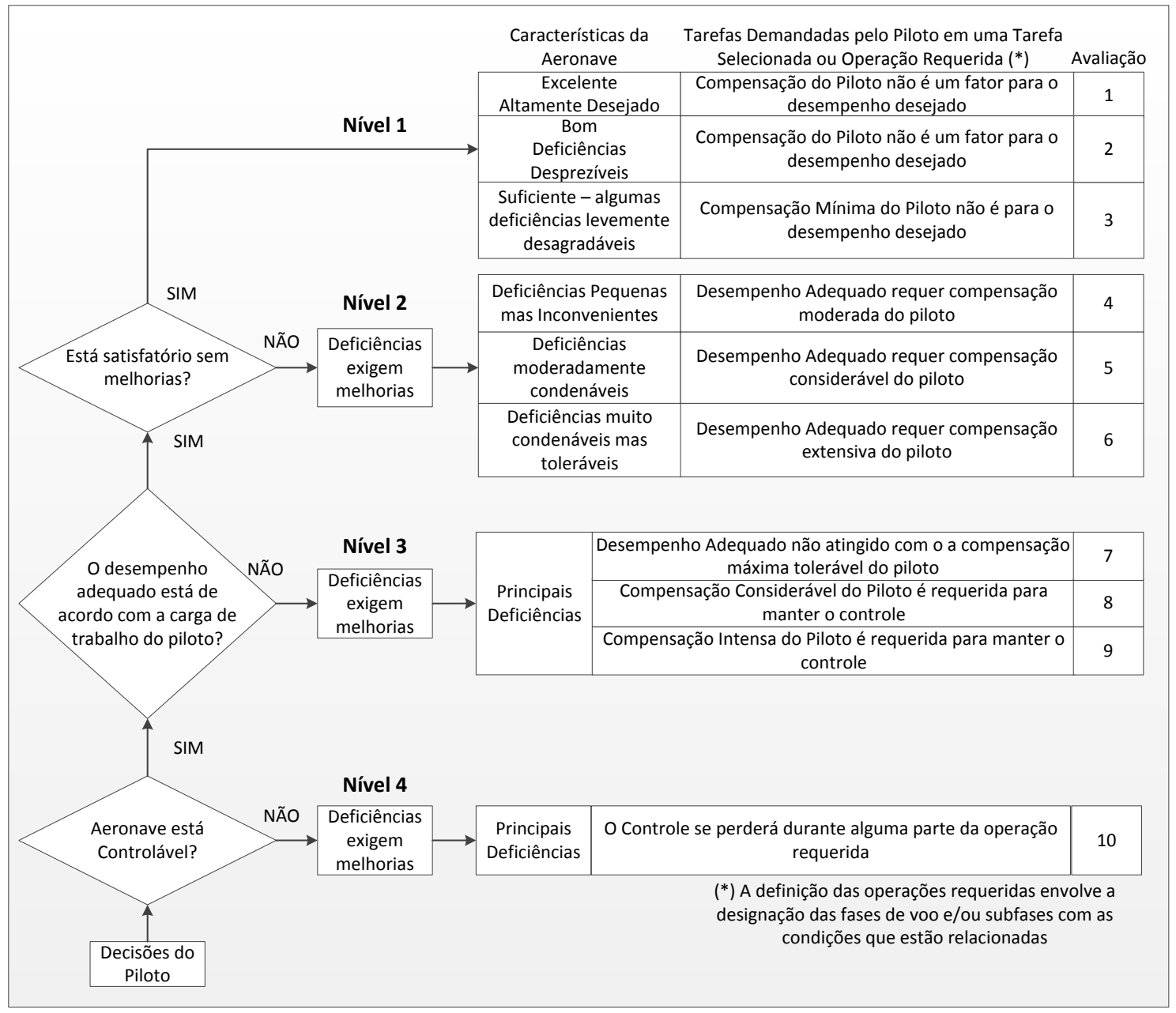

Fonte: Cooper, Harper (1986)

A primeira e mais importante definição de operação requerida na Escala Cooper Harper é qual é a utilização pretendida da aeronave para o qual a sua classificação está sendo feita (HARPER; COOPER, 1986). Esta definição deve ser explicitamente considerada e especificada e todos os aspectos que podem ser relevantes devem ser abordados. Pode-se observar que a escala de avaliação é, na verdade, um ponto de referência. A definição deve, então, incluir o que o piloto é obrigado a cumprir com a aeronave e as condições ou circunstâncias em que a operação requerida deve ser conduzida. 
As notas atribuídas por um piloto na Escala Cooper Harper representam um resumo da avaliação do piloto sob teste. Os dados críticos são os comentários que o piloto faz durante a análise da tarefa e do ambiente de voo (ou simulação de voo) sob as quais a avaliação foi realizada. Como parte da representação da escala, há três pontos de decisão que podem resultar em quatro níveis interpretados por:

- Nível 1: denota as qualidades de manuseio Desejadas sem a necessidade de melhorias - classificações de Cooper Harper entre 1 e 3;

- Nível 2: denota as qualidades que ainda apresentam deficiências que necessitam ser melhoradas, oferecendo, no entanto, condições de voo classificações de Cooper Harper entre 4 e 6;

- Nível 3: denota as qualidades que apresentam deficiências e que exigem melhoria antes de continuar com novos testes - classificações de Cooper Harper entre 7 e 9; e

- Nível 4: uma perda de controle pode significar queda da aeronave Escala Cooper Harper 10.

Assim, seguindo os níveis apresentados e utilizando uma tarefa definida para avaliar a aeronave, o piloto deve primeiro categorizar a aeronave com base nos três pontos de decisão da Figura 3.4: se é controlável; se um desempenho adequado é atingível com uma carga de trabalho tolerável do piloto; se a aeronave for insatisfatória ainda sem melhorias ou já satisfatória sem melhorias. Estas quatro categorias principais permitem ao piloto classificar a aeronave em uma escala de classificação de 1 a 10, onde 1 é uma aeronave excelente e altamente desejável e 10 sendo uma aeronave que tem grandes deficiências e exige melhoria obrigatória.

É importante notar que o número atribuído pelo piloto seguindo a escala não deve ser visto separadamente de suas anotações e justificativas, bem como qual foi a tarefa e condições dessa tarefa, caso contrário, os resultados obtidos apenas a partir das notas tornam-se passíveis de questionamento por que os utiliza (WILSON, RILEY, 1989). A avaliação da nota atribuída pelo piloto sem o contexto dos comentários ou tarefa pode causar erros de interpretação dos 
resultados obtidos e, consequentemente, uma avaliação errônea da aeronave (HARRIS, CHAN-PENSLEY, MCGARRY, 2005).

\subsection{Conceito Geral do Teste de Turing}

O Teste de Turing é utilizado para avaliar a capacidade de um equipamento composto por hardware e software de se passar por um humano em uma determinada tarefa. O Teste de Turing é apresentado a seguir de forma a balizar o conhecimento do mesmo para ser utilizado no método desenvolvido nesta Tese.

O matemático britânico Alan Turing propôs o Teste de Turing com o objetivo de ser um substituto à questão "as máquinas podem pensar?" em seu artigo Computing Machinery and Intelligence (TURING, 1950). O foco de Turing é o de prover um método que avalie se uma máquina é capaz de pensar ou não. Ele afirma que a questão "as máquinas podem pensar?" é altamente ambígua e subjetiva.

O Teste de Turing envolve um computador, um humano interrogador e outro humano que também será interrogado juntamente com o computador. $O$ interrogador deve determinar, questionando os outros dois participantes, qual deles é o computador. Toda a comunicação é feita via teclado e uma tela. $\mathrm{O}$ interrogador pode fazer questões livremente, independente de contexto, assim como o computador pode realizar qualquer atitude que force uma identificação errônea (SAYGIN et al, 2000).

Desde então, o conceito do teste de Turing, como o teste ficou conhecido, tem sido amplamente discutido em áreas de inteligência artificial, filosofia e ciência cognitiva, tanto de maneira positiva como negativa.

Para exemplificar, uma pergunta direta como "você é um computador?" deve ter como resposta, por parte do computador, que "Não, não sou um computador". Por outro lado, o humano interrogado deve ajudar o interrogador de forma que seja feita uma identificação correta. Um grande número de diferentes pessoas deve participar destes testes e, se o computador conseguir enganar um número estatisticamente suficiente de interrogadores, segundo 
Turing (1950), pode-se afirmar que o computador se passou por um humano, ou seja, por alguém com a capacidade de pensar.

Desta forma, nesta Tese, a proposta consiste em utilizar o Teste de Turing integrado com a Escala de Cooper Harper com o objetivo de tornar menos ambíguo e subjetivo o uso do da Escala Cooper Harper, permitindo uma interpretação mais uniforme dos resultados. O uso do Teste de Turing para o método apresentado na Tese é explicado na seção 4.5. 


\section{SAFETY-VANT: MÉTODO DE AVALIAÇÃO DE SEGURANÇA CRÍTICA PARA A INTEGRAÇÃO DE VANT NO ESPAÇO AÉREO CONTROLADO E NÃO SEGREGADO}

O objetivo deste capítulo é apresentar o desenvolvimento do método de avaliação de segurança crítica para a integração do VANT no Espaço Aéreo Controlado e não Segregado. O método é denominado por Safety-VANT. Tal denominação elimina eventuais ambiguidades, pois, se fosse utilizado o termo na língua portuguesa (segurança), haveria também a possibilidade de interpretação de segurança da informaçãoem vez de segurança crítica.

O Safety-VANT é um método de avaliação de segurança crítica para Veículos Aéreos Não Tripulados com Sistema Autônomo de Pilotagem embarcado que tenham seus respectivos projetos feitos para serem integrados no Espaço Aéreo Controlado e Não Segregado da mesma forma que as aeronaves tripuladas realizam essa tarefa. O desenvolvimento do método Safety-VANT utilizou os princípios da aviação civil definidos internacionalmente. Para se empregar esses princípios, o Safety-VANT se utiliza da Metodologia de Avaliação de Segurança da Eurocontrol resultando nos Requisitos Gerais de Segurança adaptados ao Sistema Autônomo de Pilotagem (SAP) do VANT descritos na Seção 4.3. A forma de quantificação desses requisitos foi desenvolvida com base na escala de Cooper Harper modificada para a realidade do SAP descrita na seção 4.4. Para se complementar a avaliação mensurada pela escala Cooper Harper Modificada, o método desenvolve a avaliação comparativa entre as tarefas avaliadas do SAP em relação aos pilotos humanos por meio do Teste de Turing apresentada na seção 4.5.

O desafio principal dos órgãos reguladores para certificar um VANT está na falta de referências adequadas para essa missão. A referência atual ainda é a aviação tripulada e esta é baseada na habilidade de pilotagem humana acumulada com o tempo, sendo complementada e validada por observação de outros humanos mais experientes na atividade de pilotar uma aeronave. A habilidade de pilotagem humana é baseada em um conhecimento não mensurável, possuindo diversos fatores subjetivos de avaliação.

A essência do controle de aeronaves por humanos adota a premissa de que a experiência de pilotos que foram certificados por outros pilotos considerados 
mais experientes é suficiente. Além da experiência humana, a confiabilidade e segurança crítica das aeronaves também apresentam constante evolução. Há situações na própria aviação civil comercial tripulada, nas quais somente os controles automatizados têm capacidade de executar determinadas tarefas de pilotagem. A título de exemplo, conforme citado no capítulo 1, o pouso designado por Categoria IIIC é realizado de forma completamente automática, sendo proibida a intervenção humana.

A capacidade de se conduzir um VANT não necessariamente deve se espelhar completamente em pilotos humanos, mas sim deve seguir as regras e protocolos definidos pelos órgãos certificadores da aviação para que o voo ocorra. Essa diferença de abordagem evita a necessidade de se transferir o conhecimento não mensurável de pilotos humanos para o VANT.

O objetivo dos órgãos certificadores é definir um meio de viabilização (por exemplo, esse meio poderia ser chamado Função Viabilidade) que deve levar em conta diversos parâmetros tais como procedimentos operacionais, tecnologias utilizadas, uso seguro do espaço aéreo, adequação de aeródromos, confiabilidade, disponibilidade e segurança crítica dos sistemas aviônicos, dentre outros.

Para o órgão certificador, o espaço aéreo em que o voo ocorre não pode ser um parâmetro decisório, pois assumiria que ele estaria segregado antes de se avaliar os demais parâmetros. A hipótese assumida nesta Tese é a de que o VANT terá capacidade de voar de forma autônoma como uma aeronave tripulada tomada como referência, no mesmo espaço aéreo dessa aeronave de referência. Dessa forma, considera-se que o VANT em avaliação está sendo analisado sem que seja julgado, a priori, incapaz ou mais inseguro que as demais aeronaves tripuladas.

Essa abordagem mantém a hipótese desta Tese de que o risco do VANT deve ter uma taxa de ocorrência de acidentes igual ou menor do que as aeronaves tripuladas. Uma possível Função Viabilidade completa requer um estudo mais amplo do desafio de integrar o VANT no espaço aéreo não segregado e controlado. Portanto, como restrição de escopo já apresentada ao longo do texto, o foco do método proposto nesta Tese é a Segurança Crítica de 
um VANT em voo, constituindo-se em uma parte vital de uma futura Função Viabilidade. Vale reforçar que, na visão da $\mathrm{OACl}$, a Segurança Crítica representa a propriedade de mais alta prioridade da aviação, devendo se manter como a propriedade que deverá ser o foco principal em todas as fases do ciclo de vida do Sistema de Controle de Tráfego Aéreo, desde a sua concepção inicial, passando pelo desenvolvimento, operação e manutenção (ICAO, 2004).

Desta forma, a proposta de um método para quantificar a qualidade de um Sistema Autônomo de Pilotagem (SAP) controlando uma aeronave torna-se fundamental para o processo de certificação desse "piloto". A utilização de processos quantificáveis tal como o método apresentado nesta Tese, permitirá às autoridades da aviação civil concretizar a integração de VANT no espaço aéreo, desde que atenda os mesmos limites de segurança aplicados à aviação civil atual.

\subsection{Desafios para a Aplicação do SAFETY-VANT}

O uso da Escala Cooper Harper, assim como a definição de requisitos de segurança, é altamente dependente da presença de especialistas, o que torna sua aplicação bastante onerosa por parte dos órgãos certificadores. O Professor John Knight da Universidade de Virgínia apresentou um estudo de caso da Marinha Norte-Americana que, para realizar uma avaliação de voo de um VANT remotamente controlado em um espaço aéreo controlado (e segregado) teve um custo de até 1 milhão de dólares em cada missão (informação verbal) ${ }^{2}$.

O objetivo do órgão certificador é prover os melhores níveis de segurança. (EUROCONTROL, 2006a) e, em um levantamento da ASTM (2006), constatouse que há diversas normas da aviação civil atual que podem ser aplicadas ao VANT, mas não há uma definição da forma de sua aplicação (DALAMAGKIDIS; VALAVANIS; PIEGL, 2012, p. 48). O método aqui definido apresenta uma forma de como se pode aplicar tais normas.

\footnotetext{
${ }^{2}$ Informação fornecida pelo prof. John Knight em reunião de pesquisa científica com os integrantes do Grupo de Análise de Segurança da Escola Politécnica da USP nos dias 13/11/2014 e 14/11/2014.
} 
A forma de validação do método depende de um processo de realimentação positiva de forma a refinar e identificar possíveis ajustes por parte de avaliadores experientes na área de certificação. Em um processo de realimentação da aplicação do método, os órgãos reguladores devem negociar e discutir os resultados obtidos juntamente com os fornecedores de forma a refinar tais resultados e apresentar, à comunidade, resultados plausíveis com a realidade.

Conforme o estudo apresentado por (CELIK, 2012), a diluição de discrepâncias que o método pode oferecer é melhorada com o passar do uso da escala em avaliações, reforçando a necessidade de validação da escala perante os órgãos reguladores. Os relatos dos avaliadores especialistas, em conjunto com a devida instrumentação de teste formalizada são necessários para fornecer base à escala para uma determinada classificação.

\subsection{Descrição do Safety-VANT}

Seguindo o raciocínio da necessidade de se conhecer, em detalhes, o problema de integração de VANT no Espaço Aéreo Controlado e Não Segregado, a primeira etapa para permitir que um VANT voe nesse espaço aéreo (de forma compartilhada ao restante do tráfego aéreo), é realizar uma comparação entre o ato de pilotar uma aeronave não tripulada e uma aeronave tripulada. Esta comparação deve ser feita sob as regras vigentes na aviação civil, visando, sobretudo, os aspectos de segurança, disponibilidade, confiabilidade e desempenho.

Porém, tal tipo de comparação entre um "piloto" autônomo SAP, um piloto humano remoto no comando da aeronave e um piloto humano a bordo da aeronave guarda relação direta com as limitações inerentes às características humanas e as limitações tecnológicas atuais, uma vez que o procedimento operacional de voo deve ser o mesmo.

Segundo as recomendações da OACI na Circular 328 (ICAO, 2011), aeronaves completamente autônomas não devem ser consideradas para voo em áreas onde já circulam aeronaves tripuladas, assim como também está proibido o transporte de seres humanos por VANT. Esta decisão apresentada pela OACI 
reflete uma visão conservadora desse órgão, coerente com suas obrigações como órgão de regulamentação da aviação civil internacional. Apesar da restrição imposta pela $\mathrm{OACl}$, a condição de voo totalmente autônomo é considerada como válida, nesta Tese, uma vez que as demais operações aéreas são casos particulares desta condição mais abrangente.

Uma possível razão para a restrição de VANT totalmente autônomo é o fator psicológico existente na sociedade referente a acidentes aéreos. Acidentes aéreos causam grande comoção e esta preocupação pode ser ainda mais agravada se houver um acidente envolvendo um VANT. A partir deste temor, podem-se derivar questões referentes à responsabilidade legal (civil e criminal) dos responsáveis pelo VANT, em caso de acidente. Se ocorrer um acidente com vítimas fatais, haverá, além do impacto social, desafios nas questões legais referentes ao julgamento de responsabilidades. No caso de VANT controlado remotamente, o piloto que estiver em seu comando poderá ou não ser responsabilizado pelo acidente, uma vez que não há jurisprudência a respeito deste tema. Diferentemente de acidentes envolvendo aviões tripulados, o piloto não estará no ambiente de risco, e isto pode afetar suas decisões, não havendo, até o momento, uma forma de mensurar se isso aumentará ou diminuirá a quantidade de acidentes em relação ao patamar atual.

É importante ressaltar que os fatores relacionados à construção e tamanho dos VANT não são considerados como um desafio para sua utilização, em qualquer parte do espaço aéreo, incluindo aeródromos, pois, independentemente do tipo e tamanho da aeronave, seja VANT ou tripulada, o Anexo14 da OACI (ICAO, 1999) define quais são as regras e limitantes a que a aeronave deve estar submetida. Isto força os construtores a se adaptarem ao aeródromo e não o inverso.

Apesar de a parte física do VANT não ser um desafio, do ponto de vista de controle, é importante observar que estas aeronaves terão de compartilhar o mesmo espaço físico nos aeródromos e, desta forma, o tamanho e peso do VANT poderão afetar os requisitos de segurança envolvidos. $O$ volume I do Anexo 14 da $\mathrm{OACl}$ apresenta, em diferentes graus, o planejamento, o projeto, 
assim como a operação e manutenção de aeródromos (ICAO, 1999). Particularmente, os capítulos 5, 6 e 7 do Anexo 14 descrevem os recursos visuais para a navegação, para se evitar obstáculos e para identificar áreas de uso restrito. Neste caso, há a necessidade de se definir como ocorrerá a movimentação de um VANT em um aeródromo. Não cabe questionar se o VANT deve ter sistema de reconhecimento por câmeras para interpretar os sinais visuais, mas sim como serão transmitidos os sinais do aeródromo para o VANT e vice versa. Há a necessidade de se definir como as regras consagradas nos anexos da $\mathrm{OACl}$ devem ser adaptadas para que a operação do VANT em um aeródromo não cause problemas de segurança, e de desempenho operacional.

O desafio de se ter pilotos humanos remotos, licenciados para comandar um VANT, deve ser tratado não somente pelo aspecto técnico, mas, sobretudo, pelo aspecto humano. A ausência de risco à própria vida causa forte impacto nas decisões do piloto e, uma vez que ele não está sujeito a esta pressão psicológica de estar a bordo da aeronave, impõe a geração de novos requisitos.

Hoje, o conhecimento humano sobre como comandar uma aeronave é bem definido do ponto de vista de treinamento e avaliação de procedimentos de voos simulados, provas de certificação e experiência mensurada por horas de voo em cada tipo de aeronave em que um piloto tenha experiência (ICAO, 2001). Vale ressaltar que a mensuração da eficiência do ser humano também é subjetiva, uma vez que não há outra "entidade" que também saiba pilotar uma aeronave, de forma que se possa realizar uma comparação entre ambas.

A ciência cognitiva não tem o objetivo de mensurar e quantificar 0 conhecimento de um humano para, então, transferi-lo para um sistema computacional (TURING, 1950; NEUMANN, 2010). Da mesma forma, não é realista mensurar e quantificar o conhecimento de um piloto para então transferi-lo ao VANT.

Sob o aspecto funcional, o "Piloto Autônomo" deve provar que é capaz de voar segundo todos os requisitos atuais a que um piloto está sujeito. Diferentemente do piloto humano, o "Piloto Autônomo" baseia-se em elementos eletrônicos, 
gerando-se a necessidade de certificar o hardware e o software que realizam a tarefa de pilotar, compondo o denominado Sistema Autônomo de Pilotagem (SAP).

Como consequência, o foco desta seção visa abordar o que é necessário para se voar em um espaço aéreo não segregado, permitindo que o desenvolvimento tenha seu foco nas regras para voar que todo piloto necessita seguir, seja autônomo ou humano remotamente no comando.

O método proposto tem como base processos já existentes de certificação de pilotos, considerando as devidas adaptações no caso do VANT, visando definir um processo de avaliação de segurança crítica. O caminho para 0 desenvolvimento do método aqui proposto é ter como ponto de referência, práticas existentes e bem estabelecidas que são utilizadas em outros domínios e aplicações do Sistema ATM Global e, então, adaptá-las para a integração de VANT neste contexto.

Considerando a futura integração do VANT no espaço aéreo, essa adaptação deve considerar as regras e definições já existentes da $\mathrm{OACl}$, tendo como uma importante contribuição, a descrição de atividades específicas a serem validadas pelo método. Os anexos da OACI que definem as regras da aviação civil internacional funcionam como leis que não podem ser violadas. O desenvolvimento de uma aeronave ou de um procedimento de controle de tráfego aéreo se preocupa com as funcionalidades (requisitos funcionais) a serem implementadas. Portanto, há a preocupação das autoridades certificadoras no sentido de verificar possíveis situações inseguras (violação das leis gerais descritas nos anexos da OACl) que podem ficar residentes no sistema (requisitos não funcionais). A Eurocontrol SAM, entre outras metodologias, respeita as leis da $\mathrm{OACl}$ e permite à equipe responsável pela avaliação da segurança crítica buscar por tais situações inseguras. Da mesma forma, esta Tese estende a metodologia de avaliação de segurança com o objetivo de avaliar a segurança crítica sobre a habilidade do VANT voar, navegar e comunicar com o sistema de controle de tráfego aéreo não segregado. 


\subsubsection{Etapas do Safety-VANT}

O método proposto por esta Tese é composto por 5 etapas, brevemente descritas a seguir:

1) Uso das regras existentes da aviação civil atualmente definidas pela $\mathrm{OACl}$;

2) Uso da Metodologia de Avaliação de Segurança da Eurocontrol (Eurocontrol SAM), descrita no capítulo 3;

3) Definição de Requisitos Gerais de Segurança, a partir do uso da Eurocontrol SAM e do conhecimento de das regras da aviação civil internacional;

4) Avaliação dos Requisitos Gerais de Segurança por meio da Escala Cooper Harper modificada ao SAP;

5) O Método de Turing aplicado ao VANT sob avaliação, utilizando os parâmetros de quantificação da Escala Cooper Harper modificada.

De posse desta base científica, pode-se definir os limites para a aplicação do método proposto bem como quantificar o método por meio da Escala Cooper Harper modificada, além de definir como realizar uma comparação com a aviação civil tripulada pelo teste de Turing.

$\mathrm{Na}$ Figura 4.1, apresenta-se o fluxograma contendo os pontos a serem considerados para a viabilização de metodologias como a Eurocontrol SAM de forma a aplicá-las aos padrões dos VANT. Na Figura 4.1, o cenário considera a integração de VANT no sistema de navegação aérea (1), indicando que é necessário definir o escopo das mudanças necessárias. Para a formalização destas mudanças, há o processo de requisitos regulatórios (2), baseados em uma documentação, explicando o que é necessário para formalizar tais mudanças. De posse da documentação das alterações (3), sabe-se o que é necessário ser avaliado (4) e, consequentemente, qual metodologia deve ser aplicada sobre as alterações (5). Dado que a Eurocontrol SAM é generalista, uma etapa necessária é aplicar esta metodologia em um domínio específico de VANT no sistema de tráfego aéreo (6) e, ao se fazer o uso desta metodologia, 
pode-se definir e propor quais etapas desta metodologia devem ser utilizadas para a formalização do método (7).

Figura 4.1 - Alterações Necessárias da Eurocontrol SAM para VANT

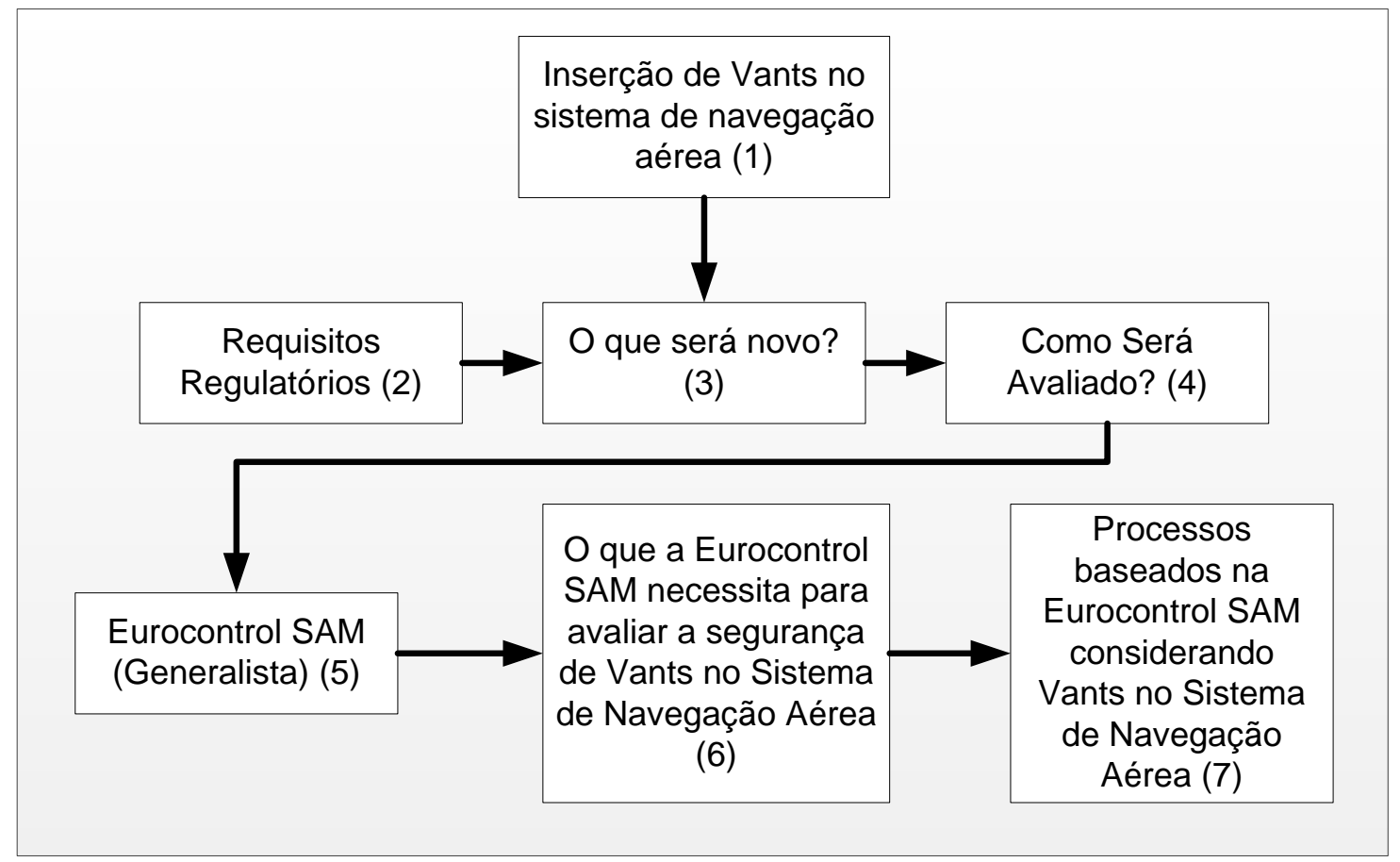

Fonte: Autor

O Safety-VANT é desenvolvido por meio do uso, integração e expansão dos conceitos apresentados no capítulo anterior: o uso da Metodologia de Avaliação de Segurança da Eurocontrol, a adaptação da Escala de Avaliação Cooper Harper e a avaliação dos resultados obtidos por meio do uso do Testes de Turing. Conforme definido no capítulo 2, o VANT sob avaliação é constituído por um Sistema Autônomo de Pilotagem (SAP) do VANT. O Safety-VANT é detalhadamente apresentado na Figura 4.2.

Em particular, para esta Tese, o domínio específico do método é restrito ao conceito do SAP, tendo assim um conjunto de elementos conhecidos a serem avaliados. Estes elementos necessitam ser definidos caso a caso, mas todos envolvem um paralelo ao que um piloto humano faria em diversas situações. Em função desta paridade com pilotos humanos, buscaram-se as formas de realização que são utilizadas na avaliação de tais profissionais, de forma a que possam ser autorizados a operar aeronaves. A forma empregada nesta Tese para essa avaliação foi o uso da Escala de Avaliação Cooper Harper 
modificada para o SAP. Esta escala possui um conjunto de critérios para avaliar a qualidade de movimentação de aeronaves durante um voo. Tais critérios de avaliação são subjetivos, o que torna o teste dependente de avaliação humana para qualificá-lo.

Considerando o Safety-VANT para a integração de VANT no espaço aéreo controlado e não segregado, utilizam-se, como base, os requisitos gerais de segurança. Esses requisitos são derivados da aplicação da Metodologia SAM da Eurocontrol, apoiado pelo Teste de Turing e pela Escala de Avaliação Cooper Harper Modificada (definida na seção 3.5), conforme mostra a Figura 4.2 .

\subsubsection{Premissas do Safety-VANT}

O Safety-VANT possui duas premissas importantes para que o método possa ser aplicado a um VANT:

1. Deve ser feito por um Especialista em avaliação de segurança crítica;

2. O hardware e o software do VANT em estudo já foi certificado por especialistas de hardware e software.

Para a primeira premissa, tem-se a situação em que o especialista conhece quais são as leis da aviação mundial no que se refere a como ocorre um voo sob controle do tráfego aéreo em espaço aéreo não controlado (regras definidas nos anexos $\mathrm{OACl}$ ). Também deve conhecer os processos de avaliação de segurança e os resultados esperados em uma avaliação de segurança.

Já para a segunda premissa, tem-se o foco da avaliação de segurança crítica de um VANT integrado ao espaço aéreo controlado e não segregado com os mesmos níveis de segurança atuais da aviação civil tripulada. Esta separação de elementos permite que o avaliador de um VANT tenha seu foco na habilidade de certificação no SAP e não em equipamentos e software agregados.

A partir dessas duas premissas, o Safety-VANT pode ser descrito de forma que não seja confundido com as próprias metodologias de avaliação de segurança 
crítica existentes. Seguindo o fluxo da Figura 4.2, um VANT (Aeronave Hardware e Software (1a) com o SAP embarcado sob avaliação (1b)), conforme definido na taxonomia apresentada, deve ser fornecido a um órgão certificador ou avaliador especialista de segurança crítica (2a).

De posse do SAP sob avaliação, O Especialista necessita dos Requisitos Gerais de Segurança relacionados ao VANT (3). Esses requisitos são gerados pelo uso da Eurocontrol SAM (3b) em função das regras da aviação civil internacional (3c) descritos e apresentados na seção 4.3. O Especialista deve então utilizar tais requisitos gerais para montar, em função das particularidades e limitações do conjunto VANT e SAP sob avaliação, os Requisitos Específicos de Segurança (RES) (4). Os requisitos específicos visam adequar o VANT aos Requisitos Gerais de Segurança. Por exemplo, seja o seguinte Requisito Geral de Segurança: "Deve considerar as normas e os procedimentos relativos aos serviços de controle de tráfego aéreo" (definido na tabela 4-2), este deve ser interpretado pelo Especialista em função da realidade do VANT sob avaliação.

O conceito de RES para esse caso deve ser entendido como "O VANT sob avaliação deve considerar as normas e procedimentos relativos aos serviços de controle de tráfego aéreo regional da área que está autorizado a voar, em função de sua categoria definida em função do porte da aeronave e rotas autorizadas de voo". Nota-se a necessidade específica de avaliar o SAP em função de um contexto pré-definido para cada avaliação. Essa forma de avaliação é feita na aviação tradicional em função das características das aeronaves e dos locais em que voam. Por exemplo, voos locais, regionais e internacionais demandam habilidade e equipamentos específicos que a avaliação de hardware e software já definiram a partir das regras gerais da aviação civil internacional.

Para cada Requisito Geral de Segurança, um ou mais Requisitos Específicos de Segurança são gerados. Apesar do refino dos Requisitos Gerais de Segurança apresentados nesta Tese por meio das tabelas 4.1 a 4.4 , o processo de realimentação e refino das mesmas por parte de novas visões de Especialistas deve ser uma atividade constante e contínua. 
De posse dos Requisitos Específicos de Segurança (5), o Especialista deve utilizar, para cada um desses requisitos, a Escala de Avaliação Cooper Harper Adaptada (6a), conforme definido pelo Safety-VANT. A Escala de Avaliação Cooper Harper Modificada (6b adaptada da escala original 6c) é apresentada na seção 4.4. A partir dessa escala, cada requisito recebe uma nota de referência atribuída pelo Especialista (7). Essa nota de referência deve ser utilizada para verificar, para cada Requisito Específico de Segurança, se a habilidade do VANT é suficientemente igual ao esperado por um humano. Essa etapa do método é realizada pelo Teste de Turing (8) descrito na seção $3.6 \mathrm{e}$ sua adaptação para ser utilizada na Tese descrita na seção 4.5. A avaliação dos resultados obtidos no Teste de Turing é então comparada com a reação humana no mesmo cenário em que o VANT está sendo testado. Essa comparação é realizada e, após o crivo de especialistas, é disponibilizada para os órgãos reguladores além de refinar a Base de Dados (9). A Base de Dados deve ser acumulativa, de forma que diferentes aplicações do método por diferentes especialistas sejam disponibilizadas. Então, dados comparativos de avaliação de segurança crítica tornam-se disponíveis para valores de referência aos órgãos certificadores para futuras referências de avaliação de segurança crítica de novos VANT.

O refino da base de dados deve ser feito em função da disponibilidade de novos VANT que venham a surgir e que sejam projetados para voar no espaço aéreo não segregado, pois, VANT que estão sendo desenvolvidos não estão sendo construídos de forma a atender as regras do espaço aéreo controlado e não segregado. A Eurocontrol estima que essa realidade de integração de VANT remotamente controlado esteja disponível a partir de 2028 e completa a partir de 2050 (EUROCONTROL, 2013).

Concluindo a avaliação, após aplicar as avaliações propostas, o Especialista possuirá em mãos os dados da avaliação desenvolvida e outras avaliações disponíveis na base de dados, podendo, então emitir um laudo que será utilizado na certificação do VANT em estudo (10). 
Figura 4.2 - Método de Avaliação de Segurança Crítica para VANT no Espaço Aéreo Controlado e Não Segregado: Safety-VANT

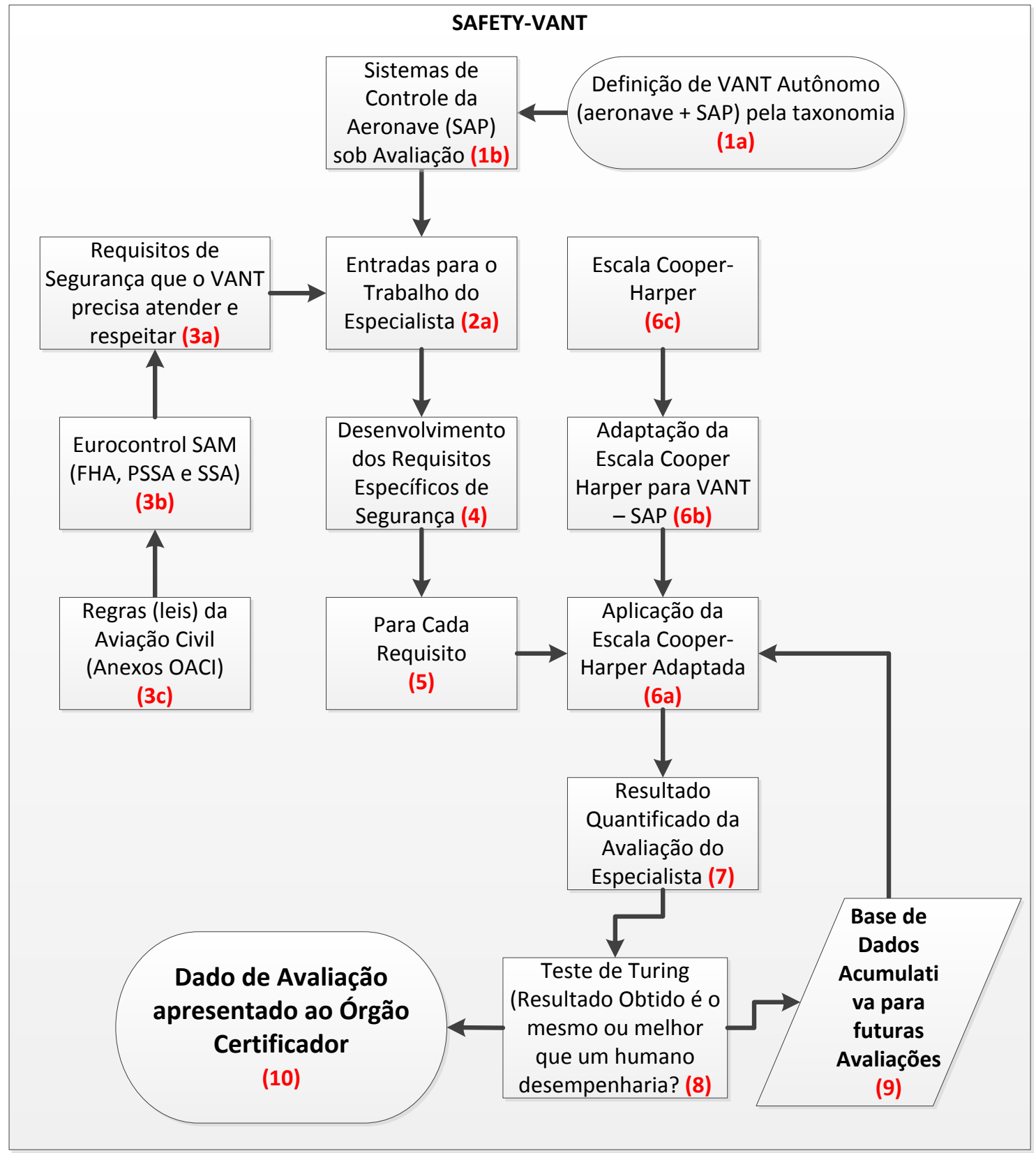

Fonte: Autor

É importante destacar que não se pretende aqui esgotar ou abranger todos os requisitos presentes na Metodologia E-SAM, ou ainda incorporar requisitos adicionais, mas sim propor o Método e mostrar sua utilidade e forma de utilização.

Deve-se notar na Figura 4.2 a importância central desempenhada pelo Especialista, ao analisar aspectos de pilotos, como habilidade de voar, navegar 
e comunicar, além de certos fatores quantitativos, com o número de horas de voo acumuladas constantes do currículo do piloto. A experiência de um piloto é registrada pelas horas de voo que ele acumula ao longo de sua carreira, além de treinamentos específicos por tipo de aeronave que ele deve pilotar. $\mathrm{Na}$ Figura 4.3, o bloco Horas de Voo Acumuladas representa uma simplificação para mera representação do processo de avaliação de capacidade de um piloto voar conforme as regras da aviação civil. Porém, a experiência de um piloto pode ser diferente de outro, mesmo que ambos tenham caminhos profissionais similares, com o mesmo número de horas de voo, podem ter tido experiências de voos diferentes.

Os passos para certificar um piloto possuem regras e métodos, mas há uma avaliação subjetiva por parte do avaliador (Procedimento para Certificar um Piloto da Figura 4.3). Da mesma forma, o avaliador que utiliza o Safety-VANT possui um peso significativo na tomada de decisão de um VANT como sendo Aprovado. Nesse paralelo de Habilidade de Voar de um SAP do VANT com a Habilidade de Voar de um piloto, a capacidade de replicar um mesmo SAP para ser avaliado por diferentes especialistas, tornando possível diferentes avaliações para exatamente um mesmo SAP, algo inviável para um piloto, dadas as suas características humanas não serem as mesmas em diferentes avaliações.

Figura 4.3 - Importância do Especialista no Método Safety-VANT

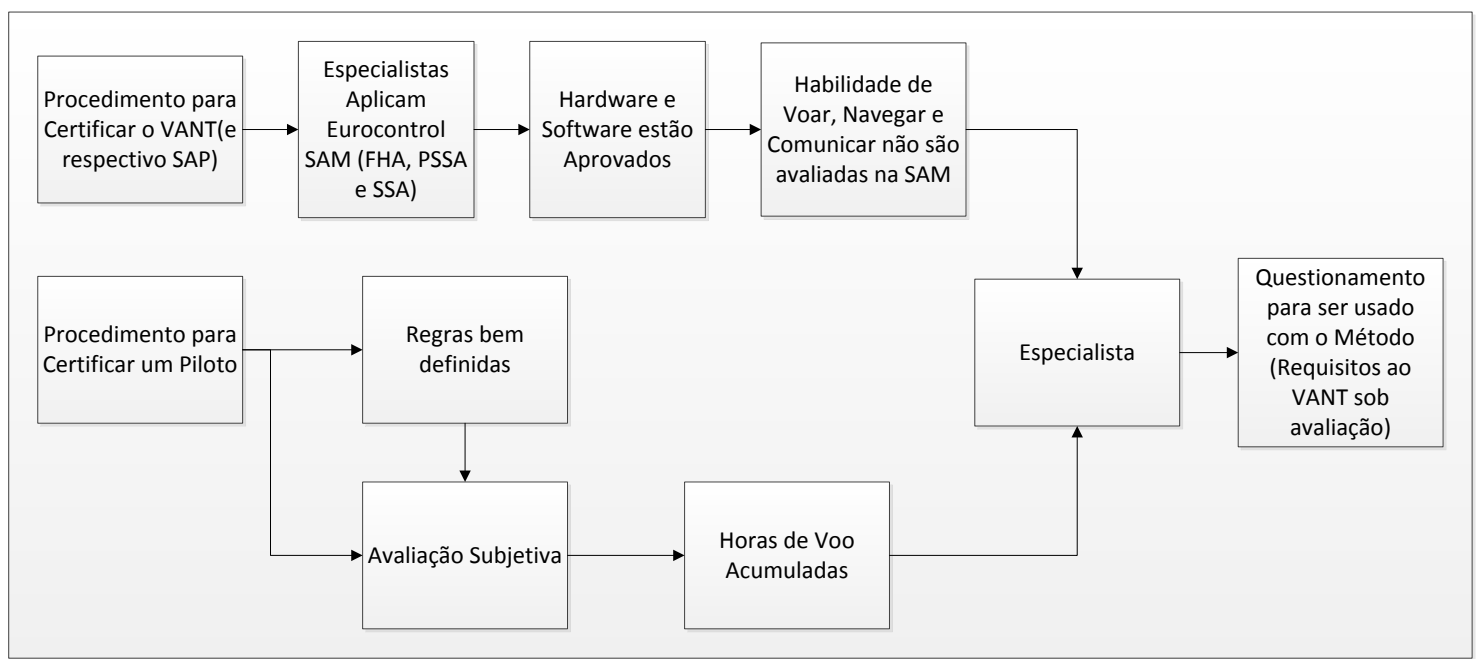

Fonte: Autor 
Ainda não há um conjunto de elementos de dimensões técnicas, sociais e mesmo políticas que os órgãos responsáveis pela segurança de voo possam usar, permitindo a certificação dos VANT e seus respectivos SAP, sejam aqueles já existentes, sejam aqueles em desenvolvimento. A viabilização do uso de VANT no espaço aéreo necessita de uma quantificação de fatores que envolvem tecnologias, regras do espaço aéreo, procedimentos operacionais (tanto em voo como em solo) e dos requisitos não funcionais de disponibilidade, confiabilidade e segurança crítica. A Função Viabilidade deve possuir esses fatores como variáveis de entrada ainda necessita ser desenvolvida pela academia. Em decorrência desta carência de quantificação, esta Tese apresenta o método proposto para expor um caminho de mensuração de parâmetros de VANT ainda mal definidos na aviação civil. Nesta Tese, a variável de estudo da Função Viabilidade concentra-se, exclusivamente, nos aspectos ligados à segurança crítica.

\subsection{Metodologia Eurocontrol SAM aplicada ao Safety-VANT}

Conforme já descrito no capítulo 3, há, em nível mundial, duas metodologias para avaliação da segurança das condições de voo de aeronaves internacionalmente utilizadas, inclusive pelas autoridades brasileiras: a da FAA e a da Eurocontrol. Ambas servem de base para todos os demais países do mundo e, consequentemente, é possível que avaliadores consigam comparar as próprias avaliações em função de uma mesma metodologia.

É importante destacar que ambas apresentam metodologias largamente consagradas. Nesta Tese, optou-se utilizar como base a metodologia da Eurocontrol pelo seu caráter multinacional, abrangendo os países da União Europeia, além de possuir uma documentação mais abrangente.

Esta Tese não visa restringir a aplicação da metodologia a uma tecnologia específica de VANT, mas sim descrever a utilização da metodologia Eurocontrol SAM no contexto do Safety-VANT, de modo a avaliar a segurança crítica do uso de VANT no Espaço Aéreo Controlado e não Segregado. Na abordagem da Eurocontrol SAM, os equipamentos são automatizados de forma 
a auxiliar as pessoas, porém, não são projetados, avaliados e certificados para que possam atuar sem a intervenção humana.

Ao se aplicar a Eurocontrol SAM para o VANT no espaço aéreo controlado e não segregado, as adaptações propostas são feitas de forma a se obter um conjunto de Requisitos Gerais de Segurança que permita a aplicação desse método a diferentes tipos de VANT, possibilitando, assim, a avaliação de segurança crítica do Sistema Autônomo de Pilotagem.

A Eurocontrol SAM não define diretamente requisitos de segurança para o ambiente aeronáutico (seja uma aeronave tripulada, um aviônico específico ou qualquer dispositivo que necessite ser avaliado), exigindo, por outro lado, que tais requisitos sejam definidos pelos fornecedores e certificadores dos equipamentos aeronáuticos.

O conceito de Requisito Geral de Segurança é um conceito abstrato na linguagem técnica de desenvolvimento de sistemas críticos, porém esses requisitos representam a pilastra de desenvolvimento de tais sistemas, pois permitem que a equipe de desenvolvimento apresente aos especialistas certificadores qual foi a base para a garantia da segurança crítica.

\subsubsection{Desenvolvimento dos Requisitos Gerais de Segurança por meio da Metodologia Eurocontrol SAM}

Esta seção descreve como foi feito o desenvolvimento dos Requisitos Gerais de Segurança de um Sistema Autônomo de Pilotagem (SAP) por meio do método Safety-VANT, aplicável a aeronaves civis não tripuladas, de modo que essas aeronaves autônomas possam ser integradas, considerando os níveis de segurança praticados, ao sistema de gerenciamento de tráfego aéreo (ATM Global).

O SAP considerado neste contexto é um sistema embarcado capaz de realizar todas as atividades de pilotagem (incluindo navegação e comunicação) de uma aeronave autônoma em um espaço aéreo controlado, sem depender de intervenções humanas para a execução de sua missão, durante qualquer fase do voo. Dessa forma, apesar desse tipo de sistema ser capaz de receber instruções de entidades humanas envolvidas no processo de gestão do tráfego 
aéreo (controladores de voo, pilotos que possam operar a aeronave remotamente ou gestores de coordenação de tráfego aéreo), considera-se que o mesmo deva ter a capacidade de tomar decisões seguras sobre a condução (pilotagem) da aeronave, independentemente da disponibilidade de recursos de comunicação com essas entidades.

Considerando a hipótese de que um VANT submetido à avaliação terá as mesmas condições operacionais de uma aeronave convencional habilitada para voar no sistema de tráfego aéreo, os Requisitos Gerais de Segurança foram desenvolvidos a partir de três pontos de vista centrais de uma avaliação de segurança crítica:

- Ponto de vista da aeronave: compreende as características necessárias para a certificação de desenvolvimento, produção e implementação dos equipamentos (aviônicos) que constituem um SAP na aeronave;

- Ponto de vista do licenciamento do piloto autônomo: engloba as características necessárias para a certificação de que o SAP está "habilitado" a controlar (de modo autônomo) uma aeronave em um espaço aéreo controlado;

- Ponto de vista da integração no ATM-Global: abrange as características necessárias para a certificação do SAP (e o respectivo veículo autônomo) no ambiente do espaço aéreo controlado.

Os Requisitos Gerais de Segurança (RGS) surgem a partir da avaliação de perigos, tais como riscos de colisão com o solo e colisão em voo descritos nas regras da aviação civil internacional.

O desenvolvimento dos RGS foi baseado no conjunto de documentação dos requisitos gerais de segurança baseados nos Requisitos Regulatórios de Segurança Crítica (Eurocontrol Safety Regulatory Requirements - ESARR) (EUROCONTROL, 2009). Como apresentado na seção 3.4, o conceito de ESARR foi desenvolvido para apoiar o processo baseado na fiscalização da segurança crítica dos provedores de serviços ATM. A Figura 4.4 apresenta a sequência utilizada para o desenvolvimento desses requisitos. A metodologia 
Eurocontrol SAM requer a identificação do objeto a ser avaliado, conforme apresentado na seção 3.4 .

O objeto adotado foi o VANT Autônomo (VANT + SAP) integrado no Espaço Aéreo Controlado e Não Segregado. Esse contexto implicou em varrer todos os anexos $\mathrm{OACl}$ aplicados atualmente para a aviação civil tripulada com o foco na Avaliação de um SAP baseado nos critérios de habilitação para pilotos humanos. A transformação de regras gerais em alto nível para requisitos gerais pôde ser realizada com base nos requisitos regulatórios da Eurocontrol. O uso da metodologia Eurocontrol SAM permitiu, então, o desenvolvimento dos requisitos gerais de segurança apresentados a seguir.

Figura 4.4 - Desenvolvimento dos Requisitos Gerais de Segurança

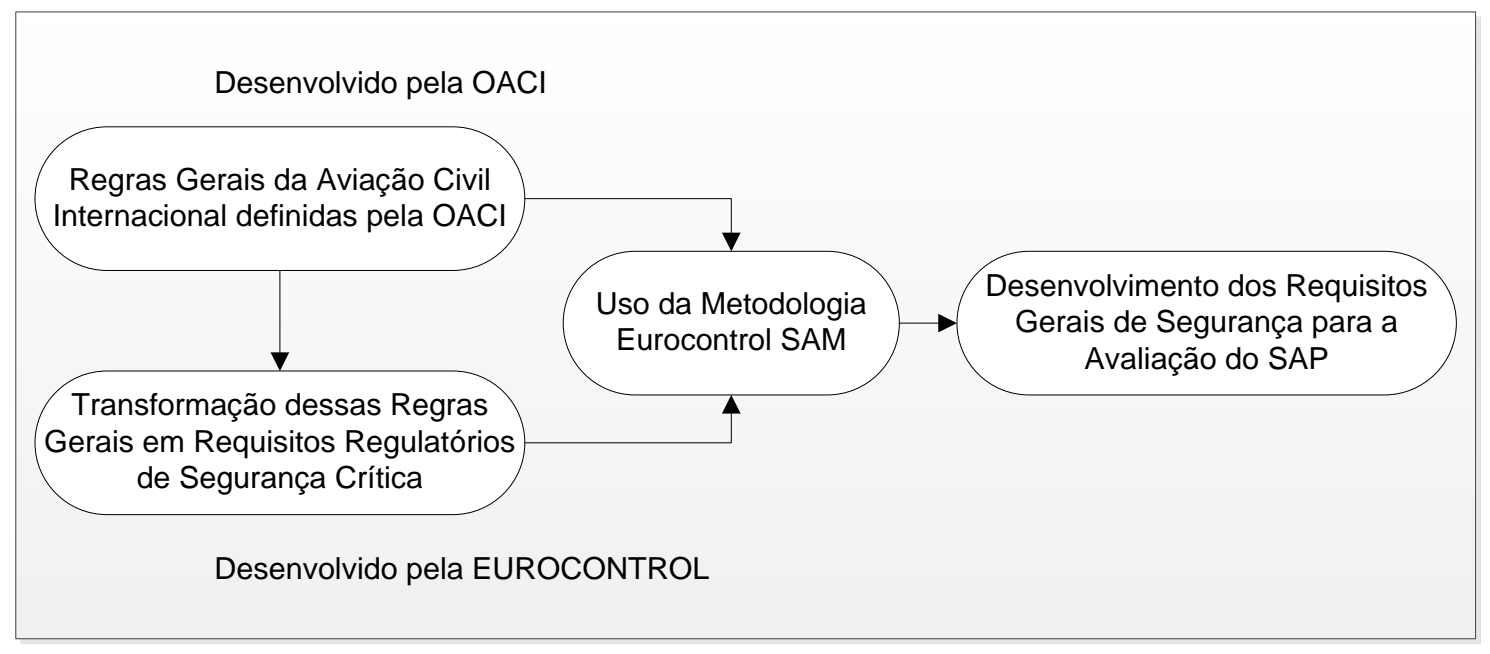

Fonte: Autor

O conceito de requisito define os elementos mínimos que devem existir nos processos de supervisão da segurança crítica operados por uma Autoridade Nacional de Fiscalização (utiliza-se, normalmente, no vocabulário aeronáutico, a sigla NSA - National Safety Authority, para designar a autoridade aeronáutica de cada nação). É importante definir que, para a Eurocontrol, qualquer atividade ou conjunto de atividades, tal como a função de supervisão de segurança do ATM, que utilize recursos para transformar entradas em saídas, pode ser considerado como um processo. No Brasil, a Autoridade Nacional de Fiscalização é a ANAC para aeronaves e o DECEA para o controle do tráfego aéreo. 
De acordo com a metodologia apresentada no capítulo 3, o E-SAM define 3 etapas importantes na avaliação de aeronaves, que são o FHA, PSSA e SSA, descritas a seguir para o desenvolvimento dos Requisitos Gerais de Segurança.

O FHA, como apresentado na Figura 3.1, tem a função de identificar os perigos relacionados ao Sistema (SAP). A etapa FHA possibilita formalizar os modos de falhas que o VANT venha a ter e possíveis danos consequentes destas falhas. $O$ forte impacto psicológico perante a sociedade ainda faz com que 0 uso de VANT tenha graus de exigência maiores que as aeronaves tripuladas. Desta forma, a tolerância a falhas é menor e, consequentemente, o processo de avaliação de perigos deve ser rigoroso o suficiente para sua aceitação.

Ao realizar o estudo dos anexos da $\mathrm{OACl}$, destacam-se os seguintes tópicos:

- Operações do VANT perante as categorias do ATM;

- $\quad$ Regras de Voo;

- Separação entre outras aeronaves;

- Separação Vertical Mínima;

- Procedimentos de Emergência;

- Interface com o ATC;

- Meteorologia;

- Equipamentos Mínimos para Comunicação, Navegação e Vigilância.

Ao se utilizar os anexos da $\mathrm{OACl}$, o levantamento do estudo de perigos ficou relacionado a tópicos gerais, pois o objetivo foi identificar os problemas no topo da cadeia de eventos, uma vez que o Safety-VANT é focado em requisitos gerais sem se prender a projetos específicos. O desenvolvimento do FHA, assim como o PSSA é um processo interativo entre equipes de desenvolvimento, assim, a lista anterior é apenas uma referência para que, em um projeto específico de avaliação, ela sirva de base aos futuros desenvolvedores. 
Há diferentes formas de identificar perigos, uma forma de identificar perigos relacionados ao VANT remotamente controlado foi descrita em Stoker e Simpson (2005). No estudo de Stoker e Simpson, foram identificados perigos de alto nível para VANT militar remotamente controlado voando em no espaço aéreo controlado e não segregado:

- Incapacidade de realizar a separação determinada pelo ATC;

- Resposta Incorreta na realização de separação instruída pelo ATC;

- Desvio intencional em relação à separação provida pelo ATC;

- $\quad$ Atraso na resposta de separação definida pelo ATC;

- Perda de Separação definida pelo ATC;

- $\quad$ Erro na instrução provida pelo ATC;

- Perda de Separação causada pelo Piloto no Comando Remoto;

- $\quad$ Erro no comando provido do Piloto para o VANT;

- $\quad$ Atraso no comando de separação.

Observa-se que, em função do escopo (VANT remotamente controlado), a avaliação de perigos identificados foi de apenas 9 perigos. Utilizando-se como parâmetro de referência o processo de desenvolvimento apresentado em Stoker e Simpson (2005), aplicou-se a metodologia Eurocontrol SAM para realizar um levantamento inicial de perigos. Esses perigos foram extraídos a partir do estudo dos Anexos da OACI relacionados com os deveres de pilotos (voo, navegação e comunicação).

Pelo processo PSSA, foi possível estender a avaliação dos perigos de forma a derivar os requisitos de segurança do sistema de forma que tais requisitos sejam necessários e suficientes para satisfazer os critérios de aceitação de segurança crítica de um SAP controlando um VANT no espaço aéreo controlado e não segregado. Vale ressaltar que o desenvolvimento de identificação de perigos e definição de requisitos é um processo qualitativo de equipes envolvidas no processo de avaliação e desenvolvimento de um determinado Sistema (LOH; BIAN; ROE, 2009). Na PSSA, como resultado, 
construiu-se um conjunto de requisitos que um SAP deveria atender em relação aos deveres de um piloto humano. Schiff (1997) cita que um piloto proficiente ganha um grau avançado de competência por meio de prática e experiência. Mas um aprofundamento de conhecimento e entendimento de como operar uma aeronave pode ter origem de uma grande variedade de fontes.

Com essa visão, além dos estudos realizados sobre os Anexos da OACl, buscou-se bibliografia relacionada aos deveres que um piloto deve seguir para ser considerado proficiente (SCHIFF 1997, 2001a, 2001b, 2003) visando manter a visão global dos requisitos de segurança além de considerar os deveres principais de um piloto humano.

Seguindo o processo de interação com outros especialistas, esses requisitos foram avaliados por outros pesquisadores e, consequentemente, produziu-se um artigo científico com o objetivo de expor esses requisitos a outros especialistas. O resultado da avaliação de revisores desse artigo resultou na publicação artigo Guidelines for the Integration of Autonomous UAS into the Global ATM (GIMENES et al., 2014).

Foi possível estabelecer evidências de segurança que devem ser verificadas em operações no espaço aéreo controlado e não segregado por meio das etapas FHA e PSSA. Em um projeto de engenharia de um VANT nesse contexto, o objetivo do FHA e PSSA seria mostrar evidências de segurança estabelecidas pelos avaliadores. Como resultado desta análise é apresentado nas tabelas 4.5 a 4.8 , os requisitos identificados que precisam ser satisfeitos para apoiar o argumento de que o VANT em avaliação é capaz de voar no contexto definido.

Os requisitos de segurança, para VANT, precisaram ser reescritos, uma vez que a arquitetura e o modelo de seu funcionamento são diferentes da aviação tradicional. Por exemplo, os VANT não possuem, necessariamente, a Interface Homem-Máquina (presente na Figura 3.2) e, assim, a princípio, não necessitariam de requisitos de segurança para este caso. Porém, algumas vezes, ela pode existir, mesmo que distante da aeronave, quando é operada remotamente. Seus requisitos de segurança, neste caso, envolvem fatores de 
disponibilidade e confiabilidade na transmissão dos dados da aeronave ao centro de controle e deste até a aeronave. Porém, os requisitos gerais de segurança são os mesmos, sejam os voos tripulados ou não.

A varredura destes elementos citados fornece ao avaliador, uma estrutura formal dos fatores envolvidos no uso do VANT, garantindo que novos fatores, ainda em estudo pela comunidade científica, sejam expostos ao voo autônomo. O objetivo do uso da E-SAM (FHA/PSSA) foi derivar um conjunto de requisitos de segurança de nível elevado, tal que, se estiverem satisfeitos, um nível aceitável de segurança pode ser demonstrado. Para que isso seja estabelecido e demonstrado, uma mitigação de riscos apropriados a cada requisito necessita ser especificada na forma de requisitos de segurança. A etapa de Avaliação de Segurança do Sistema SAP é então, demonstrar o quão seguro esse sistema está implementado. Para que isso seja demonstrado (a favor ou contra), é necessário o desenvolvimento das próximas etapas do Safety-VANT, que envolve a quantificação e julgamento do avaliador para cada requisito proposto. A etapa SSA descrita pela Eurocontrol é a avaliação do objeto estudado. Para realizar essa etapa, na Tese, aplicou-se o método sobre um VANT hipotético descrito na seção 4.6.3.

\subsubsection{Requisitos Gerais de Segurança do Ponto de Vista da Aeronave}

Do ponto de vista da aeronave, os equipamentos que constituem um SAP devem ser submetidos aos mesmos processos e critérios de construção e certificação de sistemas aviônicos, incluindo as técnicas empregadas em sistemas críticos, como, por exemplo, TCAS ou Piloto Automático.

Nesta Tese, este aspecto não é discutido, uma vez que os critérios de projeto, desenvolvimento e implementação utilizados atualmente na certificação de aviônicos em aplicações civis devem ser os mesmos aplicados à construção e certificação do equipamento que constitui um SAP. 


\subsubsection{Requisitos Gerais de Segurança do Ponto de Vista do Licenciamento do Piloto Autônomo - SAP}

Do ponto de vista do licenciamento do piloto autônomo, um SAP deve exercer as mesmas funções de um piloto humano. Dessa forma, os requisitos gerais de segurança para a avaliação e consequente certificação para o licenciamento de um SAP devem ser similares aos critérios de habilitação de pilotos humanos. Isso implica que um SAP deve possuir, no mínimo, as mesmas habilidades de um piloto humano. Assim esses critérios devem abranger todas as etapas do processo de licenciamento para voar, da mesma forma efetuada por um ser humano.

Para o licenciamento de um piloto humano são avaliados: o seu conhecimento sobre voo e aeronaves (por meio de testes específicos), as características de seu treinamento (atividades realizadas em simuladores de voo e em voos assistidos) e a sua experiência prática (registro dos voos solos sem assistência). De modo análogo, para o licenciamento de um SAP devem ser considerados: testes de sua base de conhecimento e decisão autônoma (considerando, por exemplo: a abrangência das interfaces com o processo controlado, a capacidade dos algoritmos de decisão, a robustez da lógica de controle, as características de segurança operacional), testes simulados em ambiente controlado (para avaliação do desempenho dos algoritmos de decisão em cenários simulados e assistidos) e histórico da utilização do sistema em ambientes reais de operação (GIMENES et al., 2007).

Para cada aspecto previsto na habilitação de um piloto propõe-se um critério de certificação equivalente para um SAP, de modo a garantir, no mínimo, a mesma qualidade, desempenho e precisão na tomada de decisão de ambos. Para tanto, deve-se realizar um (1) Teste de Conhecimento, (2) Treinamento de Voo e (3) Experiência de Voo. Cada um destes três itens é detalhado a seguir. Os requisitos gerais de segurança apresentados nas Tabelas 4.1 a 4.4 são baseados nos requisitos para concessão de licenças para pilotos, padronizados por organismos internacionais (ICAO, 2013). 


\subsubsection{Requisitos Gerais de Segurança para Teste de Conhecimento}

O teste de conhecimento de um SAP deve se basear no modelo de teste de conhecimento de pilotos humanos, cuja origem está baseada nos anexos da OACl (1990, 1996, 1997, 2001a, 2001b, 2001c, 2001d, 2011, 2013). Esta lista é apresentada a seguir e condensada na Tabela 4.1.

- Maturidade para a habilitação de um piloto humano:

Tem como equivalência para um SAP a exigência de sua prévia certificação como um equipamento aviônico, no qual requisitos de qualidade do produto (tais como robustez e confiabilidade) e do processo (tais como maturidade do processo de produção e qualificação de fornecedores) asseguram a adequação do hardware do equipamento para essa aplicação;

- Conhecimentos de regulação aeronáutica:

Tem como equivalência a necessidade de que os algoritmos (software aplicativo) de um SAP tenham incorporado todas as normas, procedimentos e serviços de comunicação associados ao controle de tráfego aéreo. A validação desse requisito pode ser realizada meio de um processo de avaliação independente de segurança de software;

- Conhecimentos técnicos de operação da aeronave:

Tem como equivalência a necessidade de que um SAP possua todas as interfaces necessárias para o controle do veículo, bem como inclua os algoritmos para o controle da dinâmica do veículo. A validação desse requisito pode ser realizada por testes de inspeção de software e/ou testes funcionais com simulador do veículo controlado;

- Conhecimento das limitações da aeronave (relativas à sua categoria) e de informações operacionais relativas ao manual de voo:

Tem como equivalência a necessidade de que um SAP possua algoritmos de controle (software aplicativo) com limites operacionais relativos à dinâmica do voo e com rotinas para verificação dinâmica dos limites de segurança do voo. A validação desse requisito pode ser realizada por análise do tipo de inspeção de software e/ou testes funcionais com simulador do veículo controlado; 
- Requisitos de desempenho de decolagem/pouso, planejamento de voo, efeitos de distribuição de pesos, procedimentos dos serviços de controle de tráfego aéreo:

Tem como equivalência a necessidade de que um SAP possua recursos que permitam ao usuário a configuração dos parâmetros da navegação autônoma (plano de voo, objetivos da missão, limitações de autonomia) e os parâmetros previstos para o desempenho da aeronave (tempo de execução de cada etapa da missão, velocidade de cruzeiro, limites de tráfego aéreo). A validação desse requisito pode ser realizada, por exemplo, por análise do tipo walkthrough e inspeção de software;

- Conhecimento das características de desempenho e limitações humanas:

Tem como equivalência a necessidade de que um SAP possua recursos de teste para a identificação de limitações funcionais da aeronave de modo dinâmico (em voo), bem como possua algoritmos que possam limitar ações inseguras da aeronave. A validação desse requisito pode ser realizada, por exemplo, por análise do tipo walkthrough, inspeção de software e/ou testes funcionais com simulador do veículo controlado;

- Conhecimentos de meteorologia:

Corresponde à necessidade de que um SAP possua recursos (algoritmos) para a identificação e análise de condições meteorológicas adversas, que permitam a avaliação dos riscos operacionais e a tomada de decisão autônoma em relação à mitigação desses riscos. A validação desse requisito pode ser realizada, por exemplo, por análise do tipo walkthrough, inspeção de software e/ou testes funcionais com simulador do veículo controlado;

- Conhecimento de navegação aérea (utilização de cartas aeronáuticas e técnicas de navegação estimada):

Tem como equivalência a necessidade de que um SAP possua recursos redundantes de localização e navegação, incluindo a interface com outros sistemas de navegação (comunicação de dados com outras aeronaves, sistema de localização por satélite, comunicações com pontos de referência de navegação), assim como deve possuir algoritmos para a mitigação de 
falhas relativas aos sistemas de navegação. A validação desse requisito pode ser realizada, por exemplo, por testes de análise do tipo walkthrough, inspeção de software e/ou testes funcionais com simulador do veículo controlado;

- Conhecimento dos procedimentos operacionais aeronáuticos (AIP e NOTAM):

Tem como equivalência a necessidade de que um SAP possua recursos (algoritmos) para a identificação e de análise de informações aeronáuticas, que permitam a avaliação dos riscos operacionais e a tomada de decisão autônoma em relação à mitigação desses riscos. A validação desse requisito pode ser realizada, por exemplo, por análise de inspeção de software e/ou testes funcionais com simulador do veículo controlado;

- Conhecimentos dos procedimentos de precaução e emergência (condições meteorológicas perigosas, esteira de turbulência, outros riscos operacionais):

Tem como equivalência a necessidade de que um SAP possua recursos (algoritmos) para a identificação e para a análise das condições de riscos operacionais, permitindo a tomada de decisão autônoma em relação à mitigação desses riscos. A validação desse requisito pode ser realizada, por exemplo, por análise do tipo walkthrough, inspeção de software e/ou testes funcionais com simulador do veículo controlado;

- Conhecimentos de teoria de voo:

Equivale à necessidade de que um SAP possua recursos (algoritmos) de controle da aeronave considerando as suas características aerodinâmicas e a interação das condições ambientais com essas características. A validação desse requisito pode ser realizada, por exemplo, por análise do tipo walkthrough, inspeção de software e/ou testes funcionais com simulador do veículo controlado; e 
- Conhecimento de procedimentos e fraseologia de telecomunicações (radiotelefonia) e ações de mitigação em caso de falha de comunicações navegação aérea:

Tem como equivalência a necessidade de que um SAP possua recursos de comunicação de dados com outras aeronaves (por exemplo, via CPDLC) e com outros órgãos de controle do espaço aéreo. É importante considerar, também, que o SAP possa dispor de interfaces vocais para recepção de comandos de voz de pilotos remotos e envio de respostas por canais de fonia a esses interlocutores (que existem atualmente compartilhando o espaço aéreo controlado). Tais interfaces podem ser feitas por meio de sintetizadores de voz que reproduzem as mensagens digitais CPDLC, porém, independente do uso de UAV ou não, a tecnologia CPDLC tem como objetivo substituir a comunicação primária entre pilotos e controladores atualmente conduzida por canais analógicos de voz (Gil et al, 2010). Adicionalmente, o SAP deve possuir algoritmos para a mitigação de falhas relativas aos sistemas de comunicação de dados (os canais de fonia podem representar redundâncias aos canais de dados). A validação desse requisito pode ser realizada, por exemplo, por análise do tipo walkthrough, inspeção de software e/ou testes funcionais com simulador de tráfego aéreo. 
Tabela 4.1 - Mapeamento de Requisitos Gerais de Segurança para Teste de Conhecimento

\begin{tabular}{|c|c|}
\hline $\begin{array}{l}\text { Requisitos para concessão de licenças } \\
\text { de pilotos }\end{array}$ & $\begin{array}{l}\text { Requisitos para a concessão de licença para } \\
\text { o SAP }\end{array}$ \\
\hline Maturidade (idade mínima exigida) & $\begin{array}{l}\text { Existência de certificação dos aviônicos, similar à } \\
\text { empregada em sistemas críticos }\end{array}$ \\
\hline Conhecimentos de regulação aeronáutica & $\begin{array}{l}\text { Deve considerar as normas e os procedimentos } \\
\text { relativos aos serviços de controle de tráfego } \\
\text { aéreo }\end{array}$ \\
\hline $\begin{array}{l}\text { Conhecimentos técnicos sobre operação } \\
\text { de aeronaves }\end{array}$ & $\begin{array}{l}\text { Deve considerar as características das interfaces } \\
\text { de controle e dinâmica da operação da aeronave }\end{array}$ \\
\hline $\begin{array}{l}\text { Conhecimentos das limitações } \\
\text { (restrições) relativas à categoria da } \\
\text { aeronave e informações operacionais } \\
\text { relativas ao manual de voo }\end{array}$ & $\begin{array}{l}\text { Devem considerar os limites operacionais do voo } \\
\text { e os requisitos de segurança da aeronave }\end{array}$ \\
\hline $\begin{array}{l}\text { Requisitos de desempenho e } \\
\text { planejamento de voo (prática de } \\
\text { decolagem/pouso, planejamento de voo, } \\
\text { efeitos de distribuição de pesos, } \\
\text { procedimentos dos serviços de controle } \\
\text { de tráfego aéreo) }\end{array}$ & $\begin{array}{l}\text { Devem considerar os requisitos de desempenho } \\
\text { da aeronave, as interfaces com controle de } \\
\text { tráfego aéreo e os recursos de configuração e } \\
\text { navegação autônoma }\end{array}$ \\
\hline $\begin{array}{l}\text { Conhecimento das características de } \\
\text { desempenho e limitações humanas }\end{array}$ & $\begin{array}{l}\text { Devem ser considerados requisitos de teste para } \\
\text { identificação de limitações funcionais da } \\
\text { aeronave }\end{array}$ \\
\hline Conhecimentos de meteorologia & $\begin{array}{l}\text { Devem ser considerados recursos de } \\
\text { identificação e análise de condições } \\
\text { meteorológicas adversas }\end{array}$ \\
\hline $\begin{array}{l}\text { Conhecimentos de navegação aérea } \\
\text { (utilização de cartas aeronáuticas e } \\
\text { técnicas de navegação estimada) }\end{array}$ & $\begin{array}{l}\text { Devem ser considerados requisitos de interface } \\
\text { com outros sistemas de navegação e possuir } \\
\text { técnicas de mitigação de falhas relativas à } \\
\text { navegação }\end{array}$ \\
\hline $\begin{array}{l}\text { Procedimentos operacionais aeronáuticos } \\
\text { (AIP e NOTAM) }\end{array}$ & $\begin{array}{l}\text { Devem ser considerados recursos de } \\
\text { identificação e análise de informações } \\
\text { aeronáuticas }\end{array}$ \\
\hline $\begin{array}{l}\text { Procedimentos de precaução e } \\
\text { emergência (condições meteorológicas } \\
\text { perigosas, esteira de turbulência, outros } \\
\text { riscos operacionais) }\end{array}$ & $\begin{array}{l}\text { Devem ser considerados requisitos para } \\
\text { identificação de perigos e mitigação de riscos } \\
\text { operacionais }\end{array}$ \\
\hline Conhecimentos de teoria de voo & $\begin{array}{l}\text { Deve considerar as características do ambiente } \\
\text { de voo e as características aerodinâmicas da } \\
\text { aeronave }\end{array}$ \\
\hline $\begin{array}{l}\text { Conhecimento de procedimentos e } \\
\text { fraseologia de telecomunicações } \\
\text { (radiotelefonia) e ações de mitigação em } \\
\text { caso de falha de comunicações }\end{array}$ & $\begin{array}{l}\text { Deve considerar as características das interfaces } \\
\text { e da comunicação digital via CPDLC }\end{array}$ \\
\hline
\end{tabular}




\subsubsection{Requisitos Gerais de Segurança para Treinamento de Voo}

Assim como o teste de conhecimento de um SAP, o treinamento de voo deve se basear no modelo de treinamento de voo de pilotos humanos. A lista a seguir descreve os principais elementos de um treinamento de voo necessário para se pilotar uma aeronave, sendo condensada na Tabela 4.2.

- Experiência em treinamento supervisionado com simulador de voo, para a habilitação de um piloto humano,

Tem como equivalência para um SAP, a exigência da realização de testes de certificação em ambientes simulados (por exemplo, com injeção de falhas), para verificação da adequada resposta do sistema em condições operacionais normais e adversas (conforme o tipo de missão para o qual o SAP é certificado). A validação desse requisito pode ser realizada, por exemplo, por meio de testes funcionais, acompanhados por um supervisor habilitado ou por um piloto remoto habilitado, em um ambiente simulado de tráfego aéreo;

- Experiência em instrução de voo (com instrutor habilitado, em duplo comando), para a habilitação de um piloto humano;

Tem como equivalência para um SAP, a exigência da realização de testes de certificação em ambientes reais, com aumento gradual da complexidade do tráfego. A complexidade do ambiente do tráfego aéreo deve evoluir de voos em regiões de espaço aéreo restrito (segregado), passando gradativamente até voos em espaço aéreo controlado. Esses testes devem ser conduzidos por um supervisor habilitado, podendo contar com a eventual atuação humana remota. A validação desse requisito pode ser realizada por testes funcionais, incluindo todos os procedimentos (normais e críticos), acompanhados por um supervisor certificado ou por um piloto remoto, em um ambiente simulado de tráfego aéreo; 
Esses testes devem estar associados a todas as etapas do voo (desde 0 pré-voo até a o destino final programado), considerando, no mínimo, os seguintes procedimentos:

1. Verificação (check-list) das informações da aeronave (por meio de autotestes automáticos) e do Plano de Voo (com algoritmos de verificação de consistência entre o Plano de Voo, as características da aeronave e as condições de navegação previstas);

2. Operação autônoma e assistida em voos controlados e não controlados (inclusive em região restrita), verificando os requisitos de manutenção da separação mínima;

3. Operação em ambiente real com simulação de degradação das informações da supervisão da própria aeronave (teste dos algoritmos de navegação por referências externas);

4. Operação em velocidades críticas baixas (teste dos algoritmos de identificação e recuperação de estol e parafuso);

5. Operação em velocidades críticas altas e saídas de picadas (teste de desempenho e precisão dos algoritmos de navegação em condições extremas);

6. Operação de decolagens e aterrissagens normais e com vento de través (teste de desempenho e precisão dos algoritmos de navegação em condições extremas);

7. Operação de decolagens de máximo desempenho em pista curta e ultrapassagem de obstáculos (teste de desempenho e precisão dos algoritmos de controle em condições extremas);

8. Operação de execução de curvas niveladas de 180 graus (teste de desempenho e precisão dos algoritmos de controle em condições extremas);

9. Operação em ambiente com informações degradadas de navegação (teste dos algoritmos de tolerância a falhas de dos sistemas de navegação); 10. Operações em emergência, com falhas simuladas (teste dos algoritmos de segurança em relação a falhas dos equipamentos da aeronave); 
11. Operações com origem, destino ou trânsito por aeródromos controlados (teste dos algoritmos de controle de navegação em condições de tráfego controlado).

Tabela 4.2 - Mapeamento de Requisitos Gerais de Segurança para Treinamento de Voo

\begin{tabular}{|c|c|}
\hline $\begin{array}{l}\text { Requisitos para concessão de licenças } \\
\text { de pilotos }\end{array}$ & $\begin{array}{l}\text { Requisitos para a concessão de licença para } \\
\text { o SAP }\end{array}$ \\
\hline $\begin{array}{l}\text { Experiência em treinamento } \\
\text { supervisionado com simulador de voo }\end{array}$ & $\begin{array}{l}\text { Testes em ambientes simulados (com injeção de } \\
\text { falhas) para verificação do sistema em condições } \\
\text { operacionais normais e adversas. }\end{array}$ \\
\hline & $\begin{array}{l}\text { Operação do sistema em ambientes reais com } \\
\text { aumento gradual da complexidade (inicialmente } \\
\text { voo segregado e posteriormente voo não } \\
\text { segregado em espaço aéreo não controlado) e } \\
\text { com supervisão e eventual atuação humana } \\
\text { remota. Essas operações devem incluir todos os } \\
\text { procedimentos (normais e críticos) associados a } \\
\text { todas as etapas do voo (desde o pré-voo até o } \\
\text { destino final programado). }\end{array}$ \\
\hline $\begin{array}{l}\text { Instrução de voo (com instrutor habilitado, } \\
\text { em duplo comando) cobrindo: }\end{array}$ & $\begin{array}{l}\text { Considerar, no mínimo, os seguintes } \\
\text { procedimentos: }\end{array}$ \\
\hline $\begin{array}{l}\text { Procedimentos anteriores ao voo } \\
\text { (inspeções e serviços no avião) }\end{array}$ & $\begin{array}{l}\text { Verificação (check-list) das informações da } \\
\text { aeronave e do Plano de Voo }\end{array}$ \\
\hline $\begin{array}{l}\text { Operações em aeródromos e circuitos de } \\
\text { tráfego (procedimentos para prevenção } \\
\text { de colisões) }\end{array}$ & $\begin{array}{l}\text { Operação autônoma e assistida em voos } \\
\text { segregados e não segregados, com verificação } \\
\text { de separação mínima }\end{array}$ \\
\hline $\begin{array}{l}\text { Controle do avião por referências } \\
\text { externas }\end{array}$ & $\begin{array}{l}\text { Operação em ambiente com informações } \\
\text { degradadas de informações da aeronave }\end{array}$ \\
\hline $\begin{array}{l}\text { Voo em velocidades críticas baixas } \\
\text { (reconhecimento e recuperação de estol e } \\
\text { parafuso) }\end{array}$ & $\begin{array}{l}\text { Operação em velocidades críticas baixas } \\
\text { (reconhecimento e recuperação de estol e } \\
\text { parafuso) }\end{array}$ \\
\hline $\begin{array}{l}\text { Voo em velocidades críticas altas e } \\
\text { saídas de picadas }\end{array}$ & $\begin{array}{l}\text { Operação em velocidades críticas altas e saídas } \\
\text { de picadas }\end{array}$ \\
\hline $\begin{array}{l}\text { Decolagens e aterrissagens normais e } \\
\text { com vento de través }\end{array}$ & $\begin{array}{l}\text { Operação de decolagens e aterrissagens normais } \\
\text { e com vento de través }\end{array}$ \\
\hline $\begin{array}{l}\text { Decolagens de máximo desempenho } \\
\text { (pista curta e ultrapassagem de } \\
\text { obstáculos) }\end{array}$ & $\begin{array}{l}\text { Operação de decolagens de máximo } \\
\text { desempenho (pista curta e ultrapassagem de } \\
\text { obstáculos) }\end{array}$ \\
\hline $\begin{array}{l}\text { Voo por meio de instrumentos para } \\
\text { execução de curvas de } 180 \text { graus }\end{array}$ & $\begin{array}{l}\text { Operação de execução de curvas niveladas de } \\
180 \text { graus }\end{array}$ \\
\hline $\begin{array}{l}\text { Voo de navegação por meio de } \\
\text { referências visuais, navegação estimada } \\
\text { e com rádio-navegação }\end{array}$ & $\begin{array}{l}\text { Operação em ambiente com informações } \\
\text { degradadas de navegação }\end{array}$ \\
\hline $\begin{array}{l}\text { Voo em situação de emergência (com } \\
\text { falhas simuladas) }\end{array}$ & $\begin{array}{l}\text { Operações em emergência (com falhas } \\
\text { simuladas) }\end{array}$ \\
\hline $\begin{array}{l}\text { Voo com origem, destino ou trânsito por } \\
\text { aeródromos controlados }\end{array}$ & $\begin{array}{l}\text { Operações com origem, destino ou trânsito por } \\
\text { aeródromos controlados }\end{array}$ \\
\hline
\end{tabular}




\subsubsection{Requisitos Gerais de Segurança para Experiência de Voo}

A Experiência de voo, apesar de abstrata, é possível ser observada em função de processos já utilizados na aviação comercial. A lista a seguir é baseada em processos como uso de simulador e demonstração de perícia, sendo condensada na Tabela 4.3.

- Uso de simulador certificado, voo com instrutor e voo solo em mais do que um aeródromo, para a habilitação de um piloto humano,

Tem como equivalência para um SAP, a exigência da realização de testes de certificação em ambientes reais, com aumento gradual da complexidade do tráfego. A complexidade do ambiente do tráfego aéreo deve evoluir de voos em espaço aéreo segregado (área reservada), passando, gradativamente, a voos em espaço aéreo controlado e, enfim, a voos em espaço aéreo não segregado. Esses testes devem ser conduzidos sem a dependência de um supervisor habilitado ou de atuação humana remota em condições normais de operação. A intervenção humana nesses testes deve ser considerada apenas para situações de emergência (falha do teste). A validação desse requisito pode ser realizada por testes funcionais, acompanhados por um supervisor certificado ou por um piloto remoto, em um ambiente real de tráfego aéreo;

- Demonstração de perícia para a habilitação de um piloto humano

Tem como equivalência para um SAP a exigência da operação do sistema em ambientes reais, com o objetivo de verificar a precisão dos algoritmos de controle. Esses algoritmos devem demonstrar que podem executar manobras conforme a programação de um Plano de Voo, mantendo os limites da aeronave em condições seguras, manobrando conforme o programado, controlando situações de exceção (simulação de falhas do sistema), utilizando as informações aeronáuticas e mantendo controle da aeronave durante todo o tempo de voo, com desempenho igual ou superior à de um piloto humano. 
Tabela 4.3 - Mapeamento de Requisitos Gerais de Segurança para Experiência de Voo

Requisitos para concessão de licenças de pilotos

Experiência de voo (incluindo uso de simulador homologado, voo com instrutor e voo solo em mais do que um aeródromo)
Requisitos para a concessão de licença para o SAP

Operação do sistema em ambientes reais com aumento gradual da complexidade (inicialmente voo em espaço aéreo segregado (área

reservada), passando gradativamente a voos em espaço aéreo não controlado e, enfim, a voos em espaço aéreo controlado) e sem dependência de supervisão ou atuação humana remota em condições normais. Essas operações devem incluir todos os procedimentos (normais e críticos) associados a todas as etapas do voo (desde o pré-voo até o destino final programado).

Demonstrar perícia (executar manobras com competência: manter os limites de emprego do avião, manobrar com suavidade e precisão, revelar bom julgamento e aptidão, aplicar conhecimentos aeronáuticos e manter controle da aeronave durante todo o tempo de voo)
Operação do sistema em ambientes reais com o objetivo de verificar a precisão dos algoritmos de controle (executar manobras conforme o programado: mantendo os limites da aeronave em condições seguras, manobrando conforme o programado, controlando situações de exceção (falhas), utilizando as informações aeronáuticas e mantendo controle da aeronave durante todo o tempo de voo), de modo igual ou superior a um piloto humano.

Deve-se ressaltar que o supervisor e o piloto remoto, que participam dos testes de certificação em ambiente real, também devem ser certificados conforme procedimentos estabelecidos pela OACI (ICAO, 2011).

\subsubsection{Requisitos Gerais de Segurança do Ponto de Vista do ATM Global}

O voo no espaço aéreo controlado difere do voo em espaço aéreo não controlado e, sobretudo de voo em região restrita (espaço aéreo segregado), essencialmente no que tange à interação com as autoridades do controle e com outras aeronaves, em conformidade com os procedimentos da $\mathrm{OACl}$ (ICAO, 2011), visando os aspectos de segurança de voo, com ênfase na garantia da separação mínima.

Para que um piloto humano adquira as habilidades necessárias para a execução de voos no espaço aéreo controlado é necessário que este passe por um processo de treinamento gradual (pré-solo, aperfeiçoamento e navegação) (ANAC, 2012a), (ANAC, 2004). De modo análogo, a certificação de um SAP para operação de um veículo autônomo no espaço aéreo controlado 
deve considerar a avaliação do seu desempenho nos diversos aspectos do ambiente controlado (comunicação, navegação e vigilância).

Dessa forma, para que o SAP possa conduzir um veículo autônomo no espaço aéreo controlado, é essencial que este possua habilidades de interação com as autoridades de controle de voo, bem como com outras aeronaves, sendo ainda capaz de identificar situações que possam violar os aspectos de segurança de voo.

Nesta Tese, propõe-se que a certificação de um SAP, para operação no ambiente ATM, seja realizada de modo gradual, avaliando o desempenho do sistema autônomo, inicialmente em ambiente ATM simulado e, posteriormente, em ambiente ATM real. Os itens seguintes descrevem as atividades previstas para essas duas etapas.

Dessa Forma, os Requisitos Gerais de Segurança no que tange o ATM Global, deve ser dividido pelas demandas do ambiente controlado e não segregado é apresentado na Tabela 4.4.

Tabela 4.4 - Mapeamento de Requisitos Gerais de Segurança para Integração com o ATM Global

\begin{tabular}{|c|c|}
\hline $\begin{array}{l}\text { Requisitos para concessão de licenças } \\
\text { de pilotos }\end{array}$ & $\begin{array}{l}\text { Requisitos para a concessão de licença para } \\
\text { o SAP }\end{array}$ \\
\hline $\begin{array}{l}\text { O Piloto deve ser capaz de se comunicar } \\
\text { com o Controle de Tráfego Aéreo }\end{array}$ & $\begin{array}{l}\text { O SAP deve ser capaz de se comunicar com o } \\
\text { Controle de Tráfego Aéreo }\end{array}$ \\
\hline $\begin{array}{l}\text { O Piloto deve ser capaz de realizar a } \\
\text { navegação definida no plano de voo e, } \\
\text { conforme demanda do Controle de } \\
\text { Tráfego Aéreo, alterar o plano de voo }\end{array}$ & $\begin{array}{l}\text { O SAP deve ser capaz de realizar a navegação } \\
\text { definida no plano de voo e, conforme demanda } \\
\text { do Controle de Tráfego Aéreo, alterar o plano de } \\
\text { voo }\end{array}$ \\
\hline $\begin{array}{l}\text { O Piloto deve ser capaz de reportar sua } \\
\text { posição para fins de vigilância do } \\
\text { Controle de Tráfego Aéreo por meio de } \\
\text { equipamentos necessários para voar em } \\
\text { espaço aéreo controlado e não } \\
\text { segregado. }\end{array}$ & $\begin{array}{l}\text { O SAP deve ser capaz de reportar sua posição } \\
\text { para fins de vigilância do Controle de Tráfego } \\
\text { Aéreo por meio de equipamentos necessários } \\
\text { para voar em espaço aéreo controlado e não } \\
\text { segregado. }\end{array}$ \\
\hline
\end{tabular}

\subsection{Escala Cooper Harper Modificada para o Safety-VANT}

Conforme apresentada na seção 3.5, a Escala Cooper Harper é uma escala utilizada para avaliar a qualidade de manuseio de aeronaves por pilotos experientes. Modificações da Escala Cooper Harper para a realidade de VANT tem sido feita em pesquisas científicas (CUMMINGS; MYERS; SCOTT, 2008). 
Na pesquisa de Donmez (2008), a Escala Cooper Harper foi adaptada para avaliar a qualidade dos displays de terminais remotos de pilotagem de controle do VANT. A avaliação considerava a qualidade do display do ponto de vista de navegabilidade da aeronave.

Ao se avaliar o SAP, uma adaptação da Escala Cooper Harper deve levar em conta métricas que devem ser utilizadas em uma avaliação de segurança iguais às métricas aplicadas a uma aeronave pilotada. Esta abordagem é importante estar definida uma vez que a tecnologia que constitui o VANT não está sendo avaliada em si, mas sim a capacidade do SAP de navegar e comunicar uma aeronave (VANT) nos mesmos parâmetros em que uma aeronave controlada por um humano.

\subsubsection{Importância do Avaliador Especialista no Uso da Escala Cooper Harper Modificada}

Ao contrário da escala Cooper Harper, o avaliador especialista não é o piloto da aeronave, mas sim um avaliador do SAP que tem a ação sobre o VANT. Os parâmetros de navegabilidade de um VANT tais como decolagem, pouso, precisão da navegação, capacidade de comunicação e reação a situações adversas são parâmetros que podem ser julgados pelo avaliador. Uma adaptação a essa realidade torna-se necessária, pois há uma necessidade de avaliar a habilidade de navegabilidade do "piloto" SAP no controle da aeronave VANT, ao contrário da Escala Cooper Harper original de avaliar a navegabilidade da aeronave em si. Nessa mesma linha de pesquisa, Cotting (2011) propôs uma adaptação da Escala Cooper Harper para avaliar missões de VANT militar, porém ela depende de um operador do VANT e não apresenta quais requisitos devem ser aplicados sobre o algoritmo adaptado apresentado em sua pesquisa. Com o objetivo de expandir a adaptação de Cotting (2011), a Tese apresenta uma adaptação da Escala Cooper Harper apresentada a seguir na seção 4.4.2.

Tem-se, então, além da adaptação necessária na Escala Cooper Harper, a necessidade de definição do Avaliador Especialista. A visão da NASA apresentada por Bailey (2009), em uma revisão da Escala Cooper Harper para a avaliação de qualidade de manuseio de naves espaciais, afirma que a 
"avaliação de um piloto continua a ser o único método para avaliar as interações entre o desempenho do piloto com a aeronave". Para se utilizar de forma pertinente a Escala Cooper Harper, uma vez que as avaliações são de natureza subjetiva, o histórico, o treinamento, a experiência, e o ponto de vista dos avaliadores devem ser considerados na sua seleção com base no objetivo de cada programa de teste, bem como pela utilização prevista dos dados resultantes (COOPER; HARPER, 1969). Seguindo a importância da seleção do Avaliador Especialista descrita na seção 3.5, nota-se, então, a importância do avaliador especialista que deve aplicar o Safety-VANT.

A utilização de uma mesma escala desde 1969 tem sido um valioso benefício considerável para os avaliadores, e tem geralmente encontrado aceitação internacional.

Segundo Harper; Cooper (1986), a classificação do piloto é o outro ingrediente necessário para a realização de sua avaliação. Esta afirmação corrobora a necessidade de se avaliar o SAP definido nessa Tese, pois pode-se entender que esse SAP é o produto final do processo de avaliação de uma aeronave autônoma, dando um peso a cada uma das características boas e más de como eles se relacionam com o uso pretendido da aeronave e, então, quantificar a qualidade global do conjunto piloto autônomo-aeronave.

De acordo com Mitchell et al. (2004), a Escala Cooper Harper se tornou o padrão internacional de quantificação de desempenho de pilotos a partir de um conjunto de características de uma aeronave. Essa escala tem sido aceita ao longo dos anos que se seguiram, como uma medida padrão de qualidade durante a avaliação. A utilização de uma mesma escala desde 1969 tem sido um valioso benefício considerável para os avaliadores, e tem geralmente encontrado aceitação internacional.

Embasado nessa filosofia de avaliação do Piloto separado da aeronave, a avaliação do SAP por meio de suas habilidades de voo em função de uma aeronave específica que ele esteja embarcado, a Tese apresenta uma adaptação da Escala Cooper Harper para quantificar a habilidade do SAP de voar. 


\subsubsection{Modificação da Escala Cooper Harper para Safety-VANT}

A modificação da Escala Cooper considerou a necessidade de aplicação dos Requisitos Gerais de Segurança apresentados na seção 4.3 de forma que fosse possível a aplicação de cada requisito. Da mesma forma que um piloto aprendiz é avaliado por outro piloto experiente, o SAP sob avaliação deve ser julgado por um Avaliador Especialista. A capacidade de realizar as tarefas exigidas na navegabilidade da aeronave deve ser avaliada pelo Avaliador Especialista. Portanto, os parâmetros de qualidade da Escala Cooper Harper foram adaptados de navegabilidade da aeronave para avaliar a navegabilidade do SAP em posse do controle de uma aeronave (VANT). Mantendo-se o objetivo de não avaliar a tecnologia do SAP, a Escala Cooper Harper Adaptada designa decisões do avaliador na navegabilidade da aeronave. Essa capacidade de navegabilidade do SAP é medida em uma escala de 1 a 10 da mesma forma que é feita pela Escala Cooper Harper original. A Escala Cooper Harper Modificada é apresentada na Figura 4.5.

A Escala Cooper Harper Modificada visa propiciar ao Avaliador Especialista categorias de avaliação semelhantes as apresentadas pela Escala Cooper Harper original. O fluxo de decisão deve ser percorrido pelo Avaliador está apresentado na Figura 4.5, de forma análoga ao fluxo apresentado na Figura 3.4. Dividindo-se em quatro regiões de decisão, define-se: a perda de controle durante uma tarefa em avaliação, a aeronave (VANT) está controlável ou estável sob o comando do SAP, o desempenho está adequado de acordo com a carga de operação do SAP, o desempenho da tarefa está insatisfatória ou o desempenho da tarefa está satisfatória.

A primeira etapa para se utilizar a escala é definir qual requisito geral de segurança está associado ao SAP em uma tarefa a ser executada e, em seguida, definir critérios mensuráveis para julgar se a tarefa foi executada de forma adequada em relação ao requisito escolhido. É importante observar que a definição da tarefa influencia a nota que um SAP receberá em função de um determinado requisito. Uma tarefa mal definida que pode ser de fácil realização pelo SAP permitiria uma avaliação muito mais alta, já uma tarefa que é muito difícil resultaria em uma classificação mais baixa. Os critérios de execução 
também devem ser claramente definidos e estar relacionados com os requisitos apresentados em 4.3. Possíveis ambiguidades na definição da tarefa ou requisitos inadequados gerarão resultados imprecisos no uso da escala. Isso pode resultar em classificações diferentes de um avaliador para outro mesmo para um mesmo SAP sob avaliação de um mesmo requisito.

Também na definição da tarefa a necessidade do avaliador especialista considerar a inserção de perturbação necessária durante a realização da avaliação. Alguns exemplos de perturbação podem turbulência, tesoura de vento no pouso, comandos de controle de tráfego aéreo entre outros fatores externos. Diante de tais perturbações, o SAP será avaliado e testado de forma a apresentar as informações que serão consideradas na nota do avaliador.

Da mesma forma que a escala original, a escala modificada é baseada em uma classificação que varia de 1 a 10, onde 1 é considerado o melhor resultado e 10 o resultado pior e inaceitável.

O algoritmo da Escala Copper Harper Modificada se inicia no canto inferior esquerdo da Figura 4.5. O avaliador do SAP necessita determinar se o SAP pode permanecer no controle ao executar a manobra desejada para uma determinada tarefa. Se o VANT sob o comando do SAP perder o controle do voo, melhorias ao sistema é definida como mandatória e o SAP é considerado como incapaz de voar e deve ser corrigido. O Avaliador, então define a nota como 10 no ramo de decisão.

Se o SAP consegue manter o controle durante uma tarefa exigida pelo avaliador, mas o desempenho deste mesmo SAP não consegue cumprir as exigências de desempenho adequadas. Tais deficiências exigem melhorias e a classificação é feita com notas entre 9 e 7 para avaliar as decisões de comando que o SAP apresentou ao sistema de controle do VANT. A classificação de 9 é dada a um SAP que mantém o controle da aeronave, mesmo que seja comprometido por uma perturbação específica considerada na avaliação. Não se deve considerar mais de uma perturbação ao mesmo tempo, pois isso comprometeria a comparação de futuros resultados com outros estudos similares. Uma nota A classificação de 8 é dada se o SAP mantém o controle do VANT de forma eficiente do ponto de vista do avaliador especialista 
na ausência de perturbações externas. A Avaliação com valor de 7 é plausível se o SAP mantém o controle do VANT de forma aceitável mesmo sob alguma perturbação específica. Resultados nessa faixa de resultado apresentam ao avaliador argumentos que devem ser discutidos com o desenvolvedor e quais melhorias devem ser realizadas antes de os testes continuarem. Continuar a percorrer a árvore de decisão seria possível, mas, uma vez que o desempenho já foi apresentado como insatisfatório, os resultados não teriam significado, uma vez que as deficiências detectadas e conhecidas continuariam presentes.

Tem-se, então, o próximo conjunto de decisão, com notas variando entre 6 e 4 . Se o desempenho da tarefa está adequado e pôde ser alcançado sem perturbação específica, porém, na visão do avaliador, sem margem para correção da tarefa realizada, atribui-se a nota 6 . Se a mesma tarefa for realizada de forma adequada mas com alguma perturbação específica, atribuise a nota 5. Se o desempenho do SAP é o desejado, sem perturbações externas, o SAP recebe uma classificação de 4.

Da mesma forma que a escala original, a Escala Cooper Harper Adaptada, os critérios classificados como Adequados são reservados para a classificação de 5 e 6, e os critérios classificados como Desejados são reservados para as classificações de 1 a 4 . Porém, a nota 4 deve ficar separada do conjunto de notas de 1 a 3 pois considerou a nota 4 como sendo atribuída em condições sem distúrbios externos. Reduzir as perturbações externas permitiria que o veículo consiga uma classificação de 3 , mas também faria com que as condições da tarefa sejam alteradas. Um ambiente operacional restrito pode ser definido para esse SAP atingir o desempenho desejado, mas o levaria a trabalhar em ambientes segregados, limitando o escopo da avaliação para ambientes não segregados.

A última caixa na árvore de decisão é para o desempenho da tarefa classificada como satisfatória e sem necessidade de melhorias. Esta etapa de decisão permite o avaliador informar se o SAP atende aos requisitos gerais de segurança utilizados para uma determinada tarefa e permite uma avaliação de desempenho conforme foi exigido. Uma classificação de 3 reflete que o SAP executou a tarefa sem margem de tolerância dentro dos critérios desejados 
com a presença de distúrbios externos. Uma classificação 2 permite avaliar o mesmo desempenho do SAP que a classificação 3 , mas com capacidade de lidar com alguma margem de tolerância na presença de distúrbios externos.

Uma classificação de nota 1 permite que avaliador entenda que o SAP cumpriu os requisitos gerais de segurança para a tarefa designada sem restrição de margem de atuação e exposto a perturbação externa. Uma interpretação dessa nota é de que o SAP poderia realizar uma tarefa de grau de dificuldade maior do que o apresentado a ele.

A Escala Cooper Harper considera os relatos anotados pelo piloto como parte da avaliação com o objetivo de comparação entre dados. Da mesma forma, conforme descrita a importância e o peso do conhecimento do avaliador apresentado na seção 4.1, a Escala Cooper Harper Adaptada para o SAP deve conter comentários do avaliador anexados à sua avaliação realizada para um determinado SAP.

A combinação dos comentários e a classificação para uma dada tarefa auxiliará a interpretação dos resultados em caso de variação das classificações entre os operadores. No entanto, desde que o operador humano é principalmente um observador do SAP durante a realização da tarefa de forma autônoma, a variabilidade de classificações para um mesmo SAP em uma mesma tarefa é esperada. 
Figura 4.5 - Algoritmo da Escala Cooper Harper Modificada

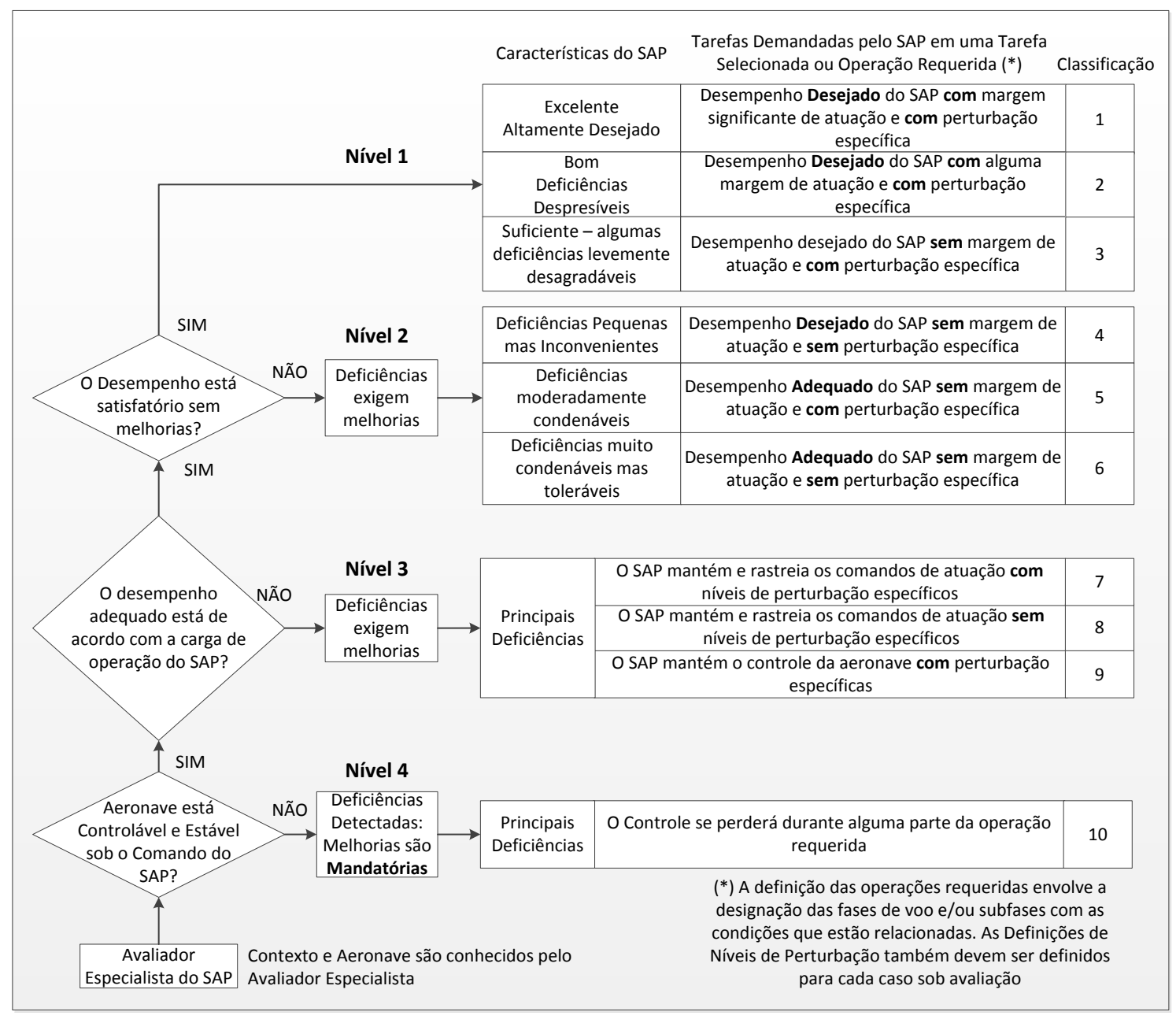

Fonte: Autor, adaptado de Cooper; Harper (1986) e Cotting (2009)

\subsection{Teste de Turing para o Safety-VANT}

Ainda há uma questão em aberto sobre a automação, não somente na aviação, mas em diversos setores em que há o uso de máquinas em tarefas anteriormente feitas pelo homem: a máquina é capaz de realizar uma tarefa feita pelo homem? A resposta será afirmativa ou negativa conforme o tipo de tarefa. Na aviação civil mundial, exige-se que se tenha um piloto para o comando da aeronave, mas, mesmo havendo um comandante humano, as aeronaves possuem um grau de automação associado. Esta automação é inerente à aeronave, independente da competência e experiência do comandante da mesma. 
No Sistema de Navegação Aérea, em um espaço aéreo controlado, um comandante deve atuar sobre a interface de controle da aeronave e comunicarse com o controle de tráfego aéreo (ATC). Na aviação civil atual, esta comunicação é feita por comandos de voz transmitidos via rádio. Caso este comandante seja um sistema autônomo, ele também deve se comunicar com o ATC, o que implica em uma nova necessidade de tecnologias que permitam que um sistema autônomo se comunique sem o uso de voz. Em particular, para o ATM Global, há o CPDLC, que consiste em uma tecnologia que permite a troca mensagens entre as aeronaves e o ATC por meio digital, sem o uso de voz.

Independente do tipo de tecnologia escolhida, um VANT que venha a voar em um espaço aéreo controlado e não segregado deve ser capaz de realizar todas as atividades que uma aeronave tripulada realiza. Porém, ao invés de se imitar a inteligência humana ao comandar uma aeronave, é mais pragmático, do ponto de vista da engenharia, que se faça um SAP capaz de comandar uma aeronave para voar de forma segura e confiável sem que, necessariamente, este controle de comando seja classificado como inteligente. Esse ponto de vista foi utilizado para a escrita dos requisitos gerais de segurança apresentados na seção 4.3.

Sob esta ótica de controle de comando, é importante para a indústria de VANT apresentar um VANT com seu respectivo SAP que mostre ser capaz de voar de forma segura e confiável, sob o controle de tráfego aéreo.

Seguindo a descrição do Safety-VANT, afirmar que o VANT apresentado pelo fabricante é seguro e confiável, o órgão regulador necessita verificar que ele tenha atendido aos requisitos gerais de segurança, que cenários de testes utilizando a Escala Cooper Harper Modificada foram aplicados. Finalmente, há a necessidade de uma interpretação comparativa entre as atividades designadas pelo SAP do VANT em relação a um piloto humano em relação aos requisitos definidos e as tarefas realizadas nos testes. Essa comparação é realizada com base no Teste de Turing explicado na seção 3.6.

A abordagem de usar o Teste de Turing para a integração de VANT no Sistema de Navegação Aérea tem o objetivo de definir métricas que compilem os 
resultados subjetivos das etapas anteriores do Safety-VANT. O Teste de Turing para a integração de VANT no Espaço Aéreo Controlado é denominado, nesta Tese, como Teste de Turing de VANT.

O uso do Teste de Turing para VANT é baseado na premissa de que, após o avaliador especialista ter atribuído uma nota para um SAP em relação à um requisito geral de segurança para uma determinada tarefa, permanece a dúvida: a habilidade do SAP para esse contexto foi suficiente? Novas pesquisas científicas necessitam ser desenvolvidas para obter respostas adequadas para essa pergunta, porém, o parâmetro atual de referência na aviação civil mundial é o piloto humano.

Desta forma, esta Tese apresenta o Safety-VANT capaz de guiar futuros testes em relação à habilidade do SAP "enganar" o Avaliador por meio do Teste de Turing de VANT, sejam simulados ou reais, independente do tipo de aeronave utilizada, tornando o método independente de limitações tecnológicas atuais.

O Teste de Turing de VANT deve ser definido nas fronteiras do objeto a ser testado. Ao contrário do Teste de Turing original em que o objetivo é enganar o interrogador (avaliador), é sabido, a priori, que se trata de um VANT em avaliação. A contribuição do Teste de Turing de VANT é apresentar ao avaliador, diante de uma tarefa sendo executada por um VANT, a pergunta para cada Requisito Geral de Segurança: "o SAP foi capaz de realizar tal tarefa igual ou melhor em relação a um piloto humano?". O Avaliador, conforme apresentado na Figura 4.6, tem o dever de analisar a interação do SAP com suas interfaces e questionar, para cada interface, se o SAP "enganou" o observador do outro lado da interface. 
Figura 4.6 - Comando da Aeronave sujeito ao Teste de Turing

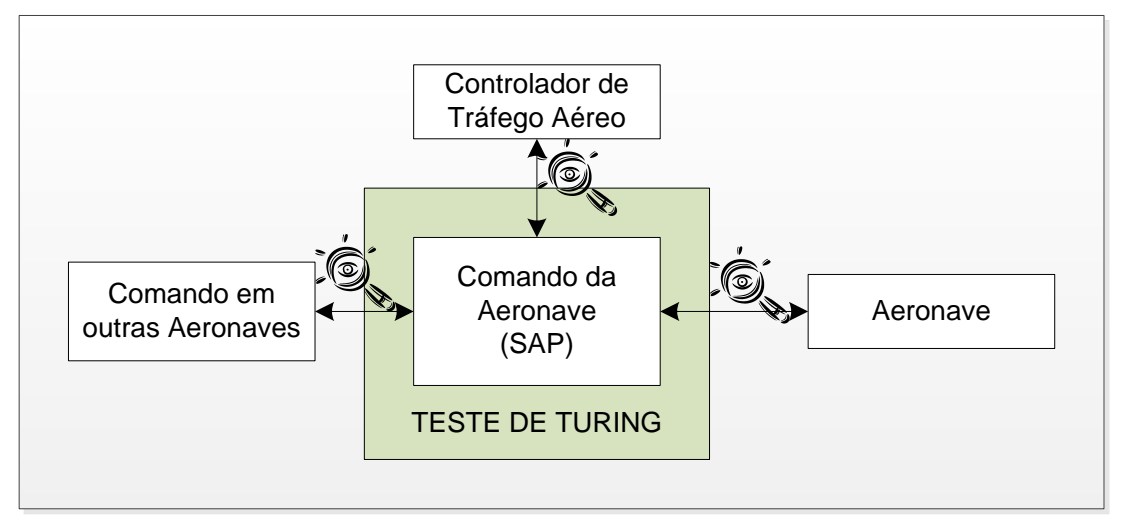

Fonte: Autor

O Comando da Aeronave pode ser feito por um piloto humano na aeronave, um piloto humano comandando a aeronave remotamente ou um controle de comando autônomo. O Teste de Turing permite que se teste apenas o Comando da Aeronave (SAP). O Teste de Turing para VANT avalia os aspectos comuns entre um SAP e um piloto, sem comparar o VANT com uma aeronave comum como fuselagem, motores, entre outros, evitando-se assim, que se tenha de testar o que já está certificado na aviação civil atual. A interface entre o Comando da aeronave e outros elementos como o Controle de Tráfego Aéreo ou outra aeronave vizinha deve ser independente do tipo de Comando presente na aeronave. Pode-se entender o Teste de Turing para VANT como um Teste Cego, onde os atores que interagem com o SAP não necessariamente saberiam que é um SAP.

O objetivo do Teste de Turing para VANT é, em posse dos requisitos gerais de segurança e do algoritmo da Escala Cooper Harper Modificada, apresentar como o avaliador especialista utiliza o resultado da escala para cada requisito. Para o resultado de nota 10, o teste não necessita ser aplicado, pois o SAP já foi reprovado pela Escala Cooper Harper Modificada. Porém, quando há aprovações intermediárias (representadas pelas notas de 9 a 1), o avaliador poderá tomar melhores decisões com o comparativo dessas notas com a habilidade de pilotos humanos em situações similares. 


\subsection{Aplicação do Método Safety-VANT}

O primeiro obstáculo que se tem nessa pesquisa é a incapacidade de se realizar simulações em grande escala, pois depende ainda de avaliação e refinamento por parte de especialistas de órgãos reguladores perante o uso 0 Safety-VANT para VANT que ainda não foram apresentados para tal avaliação.

Para fins de comparação, em um estudo da NASA (BAILEY, 2009) sobre a concepção de naves espaciais apresentou desafios similares aos apresentados nesta Tese: o desenvolvimento de aeronaves de asa rotativa e asa fixa possui um vasto histórico de projetos desenvolvidos, testes realizados, experiência acumulada e métricas de qualidade de controle de voo das mesmas. Este histórico simplificam o desenvolvimento de melhorias de uma nova aeronave assim como a qualidade de sua habilidade de voo. Segundo a NASA, essa mesma fonte histórica de dados não está disponível para naves espaciais e a avaliação de qualidade de voo, tendo de quatro ou cinco ordens de grandeza de diferença no número de nave espacial tripulada desenvolvida versus o número de aeronaves tripuladas. Sem esse legado, o processo de desenvolvimento e avaliação é visto como uma grande barreira para a engenharia para as futuras naves espaciais. Apesar disso, segundo (HODGKINSON; POTSDAM; SMITH, 1990), uma lição aprendida a partir do histórico da aviação civil tripulada é a de que "mais problemas de sistema de controle de voo são causados pelo comportamento humano do que por razões técnicas".

Em função desse obstáculo de ausência de VANT para ser avaliado, a aplicação do método Safety-VANT é feito nessa seção por meio de um exemplo de aplicação teórica sobre um VANT controlado por um SAP hipotético de forma a apresentar como ele deve ser utilizado e os resultados esperados. Conforme apresentado na seção 4.1, o estudo de caso com VANT real não é plausível nesse momento em que esta pesquisa está sendo desenvolvida. Apesar disso, a aplicação de métodos como o método SafetyVANT para a avaliação da qualidade do SAP é um componente crítico para o desenvolvimento de novos VANT.

O Método Safety-VANT necessita, para ser aplicado: 
- Avaliadores Especialistas;

- SAP e VANT sob avaliação;

- Requisitos Gerais de Segurança.

O processo de aplicação do Safety-VANT, uma vez em posse do conjunto supracitado, deve seguir os processos de boa prática de desenvolvimento de processo de avaliação de controle de aeronaves. A boa prática de processo de avaliação de qualidade navegabilidade de aeronaves (HARPER; COOPER, 1986; BAILEY, 2009) utilizada na comunidade aeronáutica é apresentada de forma adaptada na Figura 4.7 onde se apresenta as etapas que o Avaliador Especialista necessita definir com base no método Safety-VANT.

Figura 4.7 - Processo do Avaliador Especialista para Aplicar o Safety-VANT

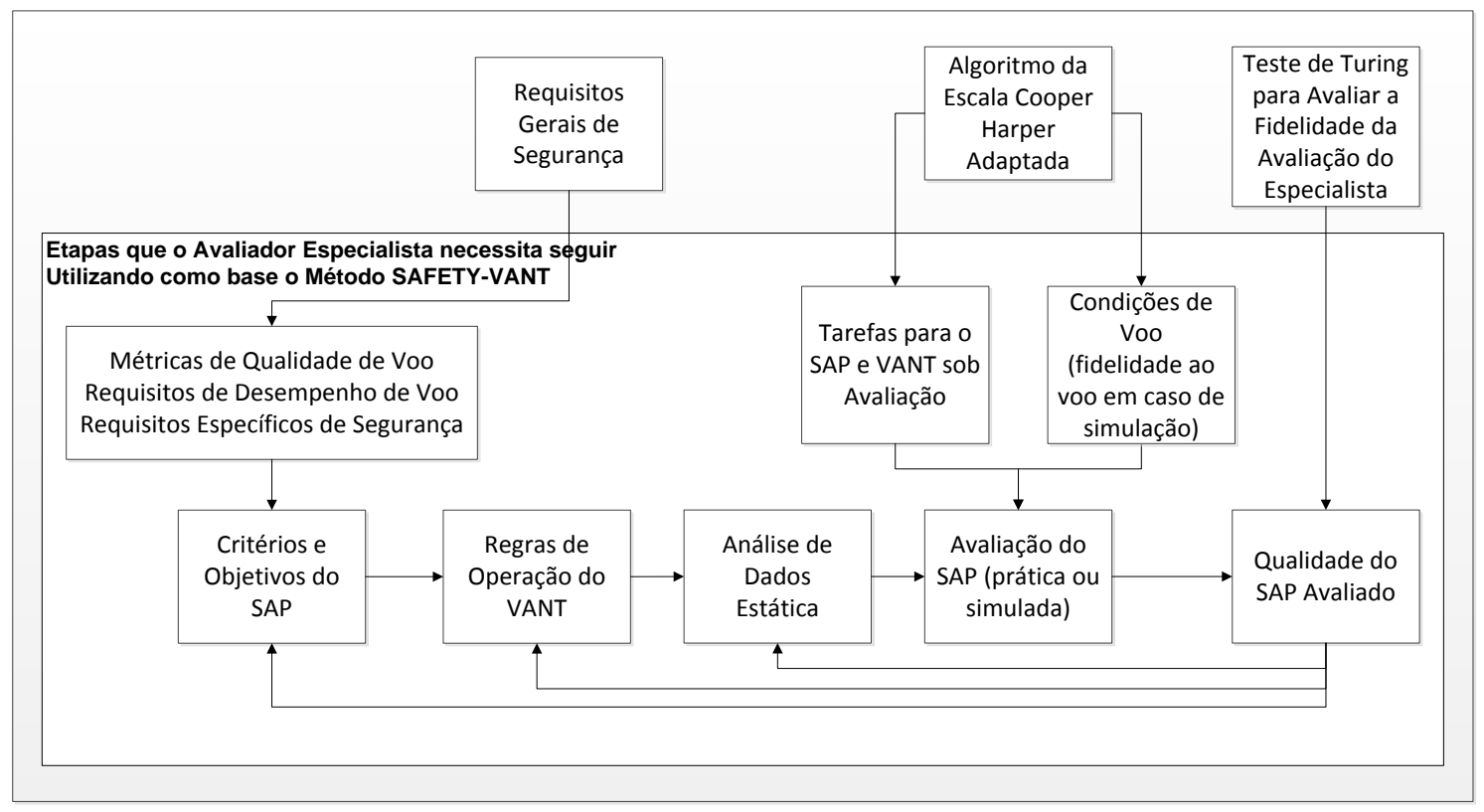

Fonte: Autor

Os Critérios e Objetivos do SAP devem ser de conhecimento do avaliador de forma que o desenvolvedor do VANT colabore com o avaliador durante o seu projeto. Os Requisitos Gerais de Segurança servem como um guia para o Avaliador definir os requisitos específicos, mas as métricas de qualidade de voo são dependentes tanto dos requisitos gerais como dos objetivos e requisitos de projetos que o SAP foi desenvolvido. Estes objetivos são 
baseados em requisitos de projeto, especificações aplicáveis, métricas de qualidade de voo existentes e experiência do passado.

As regras de operação do VANT, tendo conhecimento dos critérios e objetivos do SAP, são previamente conhecidos do avaliador. Essas Regras são relacionadas à capacidade de voo, carga máxima e outras características da aeronave VANT que o SAP opera.

Uma Análise de Dados Estática é fundamental para a compreensão da capacidade do SAP controlar a aeronave VANT, feita após definição com a equipe técnica e com os dados coletados em testes realizados. Essa análise de dados refina a base de dados para interpretar a qualidade do SAP sob avaliação.

Nesse processo de ciclo fechado, a Avaliação do SAP pode ser prática ou simulada. A realimentação do processo permite que a fidelidade e maturidade do SAP e sua habilidade de controlar a aeronave VANT, associada aos resultados práticos e simulados, cresça juntamente com o processo de desenvolvimento do próprio VANT.

O resultado do ciclo é a Qualidade do SAP avaliado quantificada pelo SafetyVANT. A NATO (BAILEY, 2009) desenvolveu práticas recomendadas que são diretamente relevantes para o desenvolvimento da Qualidade do SAP durante o seu desenvolvimento. Essas práticas recomendadas não foram propostas a serem abrangentes, mas são apropriadas para o avaliador definir os cenários de testes específicos no momento da aplicação do Safety-VANT:

1. Compreender os requisitos operacionais e a tarefa de pilotagem em cada fase da missão. Certificar-se de boa comunicação com o SAP (avaliação dos dados de resposta do SAP além das suas ações) a fim de estar plenamente ciente das condições operacionais;

2. Evitar complexidade excessiva e visar manter o projeto do SAP tão simples e tão visível quanto possível. Requisitos de testes como "o veículo deve ser capaz de ser direcionado em todas as direções, sem dificuldade de realizar manobra a qualquer momento sob equilíbrio e 
controle perfeito." São exemplos de requisitos simples a serem descritos e verificados pelo avaliador;

3. Estar atento aos sistemas de controle que visam alcançar um excelente desempenho, principalmente pela compensação de malha aberta do modelo nominal. Tal desempenho pode deteriorar-se muito rapidamente quando as tolerâncias de modelagem são introduzidas ou quando perturbações externas são aplicadas. Tais efeitos podem ser corrigidos para melhorar o desempenho de malha fechada do sistema, geralmente aumentando o ganho da realimentação, embora isso nem sempre é possível;

4. Planejar um programa de simulação integrada e certificar-se de que todos os membros de equipe (especialmente os pilotos especialistas e tomadores de decisão) estão cientes de que os vários simuladores são para fins de avaliação, para alimentar dados de volta para o processo de concepção analítica;

5. Identificar as limitações da simulação, incluindo a consideração de fornecer sugestões de procedimentos. Estar ciente de que, apesar de simuladores serem de grande valor se utilizados corretamente, eles podem dar resultados enganosos se as avaliações não são rigorosamente controladas. Apesar disso, o uso de simulação validação é altamente desejável, se não essencial;

6. Usar o simulador para complementar o projeto de análise de dados estática e ferramentas de desenvolvimento para interceptar quaisquer deficiências de projeto numa fase precoce;

7. Projetar a Interface e controle de simulação precisam ser simples para evitar interpretação errônea por quem a utiliza;

8. Calibrar o SAP para o uso de simuladores de desenvolvimento, para ajudar o seu julgamento de características de manuseio da aeronave simulada. Uma maneira de alcançar tal calibração é permitir que o SAP se "familiarize" com o simulador, ou seja, é necessária uma avaliação do Simulador em relação aos dados que este fornece ao SAP, desde que 
se tenha conhecimento prévio de habilidades do SAP para algum perfil de voo simplificado.

9. Estar ciente ao lidar com problemas, incluindo os efeitos das tolerâncias assumidas no projeto (incertezas de parâmetros) e falhas. Identificar os piores casos e fraquezas escondidas no projeto e explicar qualquer resultado inesperado de simulação;

10. Avaliar a habilidade do SAP para entrar no loop de controle, para ajudar as funções automáticas. Mostrar que não há nenhuma tendência para a divergência entre as funções de controle automático e autônoma;

11. Formar uma equipe integrada de desenvolvimento de produto para controles e para qualidade de voo, cobrindo todas as áreas de habilidade necessárias para desenvolver um sistema de controle de voo autônomo. Esta equipe deve ser responsável por controlar a concepção, desenvolvimento e teste de cada componente e a implementação e verificação de cada interface, além de estar interagindo com os avaliadores especialistas;

12. Incentivar deliberações de forma a apresentar à opinião pública especialista qualquer problema ou preocupação, para que todos os participantes possam avaliar possíveis interações com sua área de sua responsabilidade;

13. Colocar situações de estresse sobre todos os componentes do SAP, uma vez que um problema de sistema pode ser gerado por um componente que está operando corretamente dentro dos limites especificados mas que leva a uma falha insegura quando extrapolado.

Apesar de genéricas, as recomendações da NATO permitem que o SafetyVANT seja aplicado seguindo um processo de validação de projeto. A equipe de avaliadores terá, então, testado o sistema levando-o aos seus limites e compreenderá a física do problema e seus níveis de incerteza associada, na medida em que testes e verificações forem concluídos. 


\subsubsection{Escolha do Avaliador Especialista}

A primeira regra é a de que os avaliadores especialistas devem ser experientes e devem entender os conceitos de aviação civil internacional, da mesma forma que é demandado pelos pilotos avaliadores na escala Cooper Harper original (HARPER; COOPER, 1986).

\subsubsection{Uso dos Requisitos Gerais de Segurança pelos Especialistas}

O histórico de conhecimento dos avaliadores especialistas garante que haja uma interpretação correta dos requisitos necessários para avaliar a segurança crítica do SAP. A forma com que os requisitos são aplicados no contexto específico de um SAP sob avaliação reques escolhas e decisões por parte do avaliador, podendo assim ter requisitos específicos que, pela experiência do avaliador, conseguir avaliar se o SAP está apresentando convergência com os requisitos gerais.

O avaliador tem, então, como dever, descrever os cenários em que o VANT irá voar, quais condições o voo ocorre e, seguindo os passos apresentados na Escala Cooper Harper Modificado, para cada condição de voo e para cada requisito geral de segurança utilizado, testar o SAP sob um conjunto de tarefas e condições externas presentes na escala. Uma vez aplicada a escala, tem-se a nota para cada conjunto de tarefa, requisito e condições definidas que, conforme a experiência do avaliador, faz a avaliação do Teste de Turing de cada nota obtida pelo SAP.

\subsubsection{Exemplo de Aplicação para o Safety-VANT}

Nesta seção apresenta-se um cenário hipotético de como seria avaliar um SAP embarcado em um VANT pelo Safety-VANT. Este exemplo de aplicação teórica sobre um VANT controlado por um SAP hipotético visa apresentar a forma que - SAP deve ser avaliado. Porém, como explicado nas seções anteriores, a descrição completa de um estudo de caso depende de elementos não disponíveis nessa Tese.

Considera-se que os Requisitos Gerais de Segurança do Ponto de Vista da Aeronave já sejam atendidos, pois a navegabilidade da aeronave em que o 
SAP está embarcado passou pelo processo de avaliação de segurança de hardware e software (incluindo fuselagem, sensores, atuadores e aviônicos necessários para o SAP comandar a aeronave).

Seguindo para os Requisitos Gerais de Segurança do Ponto de Vista do Licenciamento do Piloto Autônomo - SAP (tabelas 4.1, à 4.4), a partir dos três pontos de desenvolvimentos (1) Teste de Conhecimento, (2) Treinamento de Voo e (3) Experiência de Voo, deve-se, então, aplicar a Escala Cooper Harper para cara linha dessas tabelas para o VANT em avaliação. A aplicação é feita pelo Teste de Turing, utilizando-se o conhecimento prévio de como um piloto humano realizaria este teste da melhor forma possível. Esta condição tem o objetivo de comparar o VANT sob avaliação com os parâmetros mais rígidos possíveis.

Assume-se o VANT Hipotético como sendo o VANT autônomo controlado pelo SAP embarcado. Esse SAP foi projetado para ser capaz de voar, navegar e comunicar com o ATC de forma transparente aos demais atores envolvidos no gerenciamento de tráfego aéreo que possam interagir com esse VANT. Naturalmente, conforme descrito nessa seção, a avaliação desse VANT ocorreria durante o seu processo de desenvolvimento, mas, para fins de exposição da forma de uso do Safety-VANT, considera-se, nessa situação, que - VANT foi apresentado ao avaliador especialista depois de ter sido desenvolvido.

De posse do VANT sob avaliação, o especialista que o avaliará deve, como primeiro passo, entender as especificações da aeronave VANT (condições de voo, limites de navegabilidade aérea, velocidade de decolagem, velocidade de sustentação mínima, entre outros).

Tendo conhecimento do tipo de aeronave VANT que o SAP deve comandar, o especialista iniciaria a etapa de desenvolvimento dos requisitos específicos de segurança e, consequentemente, os cenários de testes para validá-los. Essa etapa consiste em um projeto de engenharia para um determinado produto (VANT+SAP) que não se justifica ser desenvolvido no corpo da Tese. Para fins de ilustração da aplicação do método Safety-VANT, a avaliação do VANT foi 
feita diretamente sob os requisitos gerais de segurança desenvolvidos na seção 4.3.

As Tabelas 4.5, 4.6, 4.7 e 4.8 foram desenvolvidas utilizando-se, na terceira coluna, o resultado que se teria ao aplicar a Escala Cooper Harper Adaptada. Uma vez que o SAP foi quantificado pela escala, o Teste de Turing é aplicado, na visão do avaliador, com o objetivo de saber se o requisito que o SAP está sob teste foi atendido, ou seja, o SAP foi capaz de realizar a tarefa especificada da mesma forma que um piloto humano realizaria para o determinado requisito? As respostas acumuladas de diferentes avaliadores para o mesmo cenário permite que futuros tomadores de decisão para a certificação do SAP tenham resultados de diferentes avaliadores sob a capacidade do SAP "se passar" por um piloto humano. 
Tabela 4.5 - Avaliação de um SAP baseado nos critérios de habilitação para pilotos humanos: Teste de Conhecimento do SAP

\begin{tabular}{|c|c|c|c|}
\hline $\begin{array}{l}\text { Requisitos para } \\
\text { concessão de } \\
\text { licenças de pilotos }\end{array}$ & $\begin{array}{l}\text { Requisitos para a } \\
\text { concessão de licença } \\
\text { para o SAP }\end{array}$ & $\begin{array}{l}\text { Resultados da } \\
\text { Inspeção do } \\
\text { Avaliador: Escala } \\
\text { Cooper Harper } \\
\text { Adaptada (Figura 4.5) }\end{array}$ & $\begin{array}{l}\text { Avaliação } \\
\text { Qualitativa } \\
\text { pelo Teste de } \\
\text { Turing: SAP } \\
\text { convenceu o } \\
\text { Interlocutor? }\end{array}$ \\
\hline $\begin{array}{l}\text { Maturidade (idade } \\
\text { mínima exigida) }\end{array}$ & $\begin{array}{l}\text { Existência de } \\
\text { certificação dos } \\
\text { aviônicos, similar à } \\
\text { empregada em } \\
\text { sistemas críticos } \\
\end{array}$ & $\begin{array}{l}\text { Não Aplicável à } \\
\text { Escala Cooper } \\
\text { Harper. Verificação } \\
\text { prévia pelo Avaliador. }\end{array}$ & Não Aplicável \\
\hline $\begin{array}{l}\text { Conhecimentos de } \\
\text { regulação aeronáutica }\end{array}$ & $\begin{array}{l}\text { Deve considerar as } \\
\text { normas e os } \\
\text { procedimentos relativos } \\
\text { aos serviços de controle } \\
\text { de tráfego aéreo }\end{array}$ & $\begin{array}{l}\text { O SAP atendeu } \\
\text { satisfatoriamente o } \\
\text { requisito. Nota de } \\
\text { Avaliação Cooper } \\
\text { Harper: } 6 \text {. As regras } \\
\text { de regulação } \\
\text { aeronáutica foram } \\
\text { estressadas em voo e } \\
\text { o SAP exerceu o voo } \\
\text { da mesma forma e } \\
\text { limitações que um } \\
\text { humano sob as } \\
\text { mesmas condições. }\end{array}$ & $\begin{array}{l}\text { Sim. } \\
\text { Compatível com } \\
\text { a habilidade de } \\
\text { voo humana. }\end{array}$ \\
\hline $\begin{array}{l}\text { Conhecimentos } \\
\text { técnicos sobre } \\
\text { operação de aeronaves }\end{array}$ & $\begin{array}{l}\text { Deve considerar as } \\
\text { características das } \\
\text { interfaces de controle e } \\
\text { dinâmica da operação } \\
\text { da aeronave }\end{array}$ & $\begin{array}{l}\text { O desempenho do } \\
\text { voo, sob manobras } \\
\text { específicas foi } \\
\text { satisfatório. Nota de } \\
\text { Avaliação Cooper } \\
\text { Harper: } 6 \text {. Atingiu as } \\
\text { condições mínimas de } \\
\text { navegabilidade, } \\
\text { quando exposto ao } \\
\text { Teste de Turing. }\end{array}$ & $\begin{array}{l}\text { Não. A forma } \\
\text { com que as } \\
\text { tarefas foram } \\
\text { executadas não } \\
\text { foram as que } \\
\text { um humano } \\
\text { realizaria. } \\
\text { Verificar o } \\
\text { histórico para } \\
\text { análise. }\end{array}$ \\
\hline $\begin{array}{l}\text { Conhecimentos das } \\
\text { limitações (restrições) } \\
\text { relativas à categoria da } \\
\text { aeronave e } \\
\text { informações } \\
\text { operacionais relativas } \\
\text { ao manual de voo }\end{array}$ & $\begin{array}{l}\text { Devem considerar os } \\
\text { limites operacionais do } \\
\text { voo e os requisitos de } \\
\text { segurança da aeronave }\end{array}$ & $\begin{array}{l}\text { O SAP do VANT se } \\
\text { comportou como um } \\
\text { controle de aeronave } \\
\text { diferente da aeronave } \\
\text { sob teste. Nota de } \\
\text { Avaliação Cooper } \\
\text { Harper: } 3 \text {. }\end{array}$ & $\begin{array}{l}\text { Não. } \\
\text { Incompatível } \\
\text { com a } \\
\text { habilidade de } \\
\text { voo humana. }\end{array}$ \\
\hline $\begin{array}{l}\text { Requisitos de } \\
\text { desempenho e } \\
\text { planejamento de voo } \\
\text { (prática de } \\
\text { decolagem/pouso, } \\
\text { planejamento de voo, } \\
\text { efeitos de distribuição } \\
\text { de pesos, } \\
\text { procedimentos dos } \\
\text { serviços de controle de } \\
\text { tráfego aéreo) }\end{array}$ & $\begin{array}{l}\text { Devem considerar os } \\
\text { requisitos de } \\
\text { desempenho da } \\
\text { aeronave, as interfaces } \\
\text { com controle de tráfego } \\
\text { aéreo e os recursos de } \\
\text { configuração e } \\
\text { navegação autônoma }\end{array}$ & $\begin{array}{l}\text { O Plano de Voo } \\
\text { seguido pelo SAP } \\
\text { atendeu ao Plano de } \\
\text { Voo original, } \\
\text { Nota de Avaliação } \\
\text { Cooper Harper: } 2 \text {. }\end{array}$ & $\begin{array}{l}\text { Sim. } \\
\text { Compatível com } \\
\text { a habilidade de } \\
\text { voo humana. }\end{array}$ \\
\hline Conhecimento das & Devem ser & O SAP não consegue & Não. \\
\hline
\end{tabular}




\begin{tabular}{|c|c|c|c|}
\hline $\begin{array}{l}\text { Requisitos para } \\
\text { concessão de } \\
\text { licenças de pilotos }\end{array}$ & $\begin{array}{l}\text { Requisitos para a } \\
\text { concessão de licença } \\
\text { para o SAP }\end{array}$ & $\begin{array}{l}\text { Resultados da } \\
\text { Inspeção do } \\
\text { Avaliador: Escala } \\
\text { Cooper Harper } \\
\text { Adaptada (Figura 4.5) }\end{array}$ & $\begin{array}{l}\text { Avaliação } \\
\text { Qualitativa } \\
\text { pelo Teste de } \\
\text { Turing: SAP } \\
\text { convenceu o } \\
\text { Interlocutor? }\end{array}$ \\
\hline $\begin{array}{l}\text { características de } \\
\text { desempenho e } \\
\text { limitações humanas }\end{array}$ & $\begin{array}{l}\text { considerados requisitos } \\
\text { de teste para } \\
\text { identificação de } \\
\text { limitações funcionais da } \\
\text { aeronave }\end{array}$ & $\begin{array}{l}\text { reagir em situação de } \\
\text { perda de turbinas, não } \\
\text { garantindo o planeio } \\
\text { da aeronave em } \\
\text { pouso de emergência. } \\
\text { Nota de Avaliação } \\
\text { Cooper Harper: } 9 \text {. }\end{array}$ & $\begin{array}{l}\text { Incompatível } \\
\text { com a } \\
\text { habilidade de } \\
\text { voo humana. }\end{array}$ \\
\hline $\begin{array}{l}\text { Conhecimentos de } \\
\text { navegação aérea } \\
\text { (utilização de cartas } \\
\text { aeronáuticas e técnicas } \\
\text { de navegação } \\
\text { estimada) }\end{array}$ & $\begin{array}{l}\text { Devem ser } \\
\text { considerados requisitos } \\
\text { de interface com outros } \\
\text { sistemas de navegação } \\
\text { e possuir técnicas de } \\
\text { mitigação de falhas } \\
\text { relativas à navegação }\end{array}$ & $\begin{array}{l}\text { A capacidade de } \\
\text { seguir o plano de voo } \\
\text { foi realizada com } \\
\text { sucesso, mesmo } \\
\text { diante de condição } \\
\text { climática desfavorável. } \\
\text { Nota de Avaliação } \\
\text { Cooper Harper: } 2\end{array}$ & $\begin{array}{l}\text { Sim. } \\
\text { Compatível com } \\
\text { a habilidade de } \\
\text { voo humana. }\end{array}$ \\
\hline $\begin{array}{l}\text { Procedimentos } \\
\text { operacionais } \\
\text { aeronáuticos (AIP e } \\
\text { NOTAM) }\end{array}$ & $\begin{array}{l}\text { Devem ser } \\
\text { considerados recursos } \\
\text { de identificação e } \\
\text { análise de informações } \\
\text { aeronáuticas }\end{array}$ & $\begin{array}{l}\text { Respeitou a simulação } \\
\text { da alteração de } \\
\text { NOTAM imposta. Nota } \\
\text { de Avaliação Cooper } \\
\text { Harper: } 3\end{array}$ & $\begin{array}{l}\text { Não. } \\
\text { Incompatível } \\
\text { com a } \\
\text { habilidade de } \\
\text { voo humana. } \\
\text { Realizou a } \\
\text { tarefa de forma } \\
\text { não natural. }\end{array}$ \\
\hline $\begin{array}{l}\text { Procedimentos de } \\
\text { precaução e } \\
\text { emergência (condições } \\
\text { meteorológicas } \\
\text { perigosas, esteira de } \\
\text { turbulência, outros } \\
\text { riscos operacionais) } \\
\end{array}$ & $\begin{array}{l}\text { Devem ser } \\
\text { considerados requisitos } \\
\text { para identificação de } \\
\text { perigos e mitigação de } \\
\text { riscos operacionais }\end{array}$ & $\begin{array}{l}\text { Demonstrou total } \\
\text { instabilidade diante } \\
\text { das situações de } \\
\text { perigo apresentas. } \\
\text { Nota de Avaliação } \\
\text { Cooper Harper:10 }\end{array}$ & $\begin{array}{l}\text { Não. } \\
\text { Incompatível } \\
\text { com a } \\
\text { habilidade de } \\
\text { voo humana. }\end{array}$ \\
\hline $\begin{array}{l}\text { Conhecimentos de } \\
\text { teoria de voo }\end{array}$ & $\begin{array}{l}\text { Deve considerar as } \\
\text { características do } \\
\text { ambiente de voo e as } \\
\text { características } \\
\text { aerodinâmicas da } \\
\text { aeronave }\end{array}$ & $\begin{array}{l}\text { Em condições sem } \\
\text { interferência externa, } \\
\text { realizou a tarefa } \\
\text { desejada. } \\
\text { Nota de Avaliação } \\
\text { Cooper Harper: } 3\end{array}$ & $\begin{array}{l}\text { Sim. } \\
\text { Compatível com } \\
\text { a habilidade de } \\
\text { voo humana, } \\
\text { mas passível de } \\
\text { melhorias. }\end{array}$ \\
\hline $\begin{array}{l}\text { Conhecimento de } \\
\text { procedimentos e } \\
\text { fraseologia de } \\
\text { telecomunicações } \\
\text { (radiotelefonia) e ações } \\
\text { de mitigação em caso } \\
\text { de falha de } \\
\text { comunicações }\end{array}$ & $\begin{array}{l}\text { Deve considerar as } \\
\text { características das } \\
\text { interfaces e da } \\
\text { comunicação digital. }\end{array}$ & $\begin{array}{l}\text { Fraseologia, } \\
\text { interpretação de } \\
\text { comandos do ATC e } \\
\text { respostas corretas. } \\
\text { Nota de Avaliação } \\
\text { Cooper Harper: } 2\end{array}$ & $\begin{array}{l}\text { Sim. } \\
\text { Compatível com } \\
\text { a habilidade de } \\
\text { voo humana. } \\
\text { Porém, correta } \\
\text { a ponto de se } \\
\text { perceber que } \\
\text { não é um } \\
\text { humano. }\end{array}$ \\
\hline
\end{tabular}


Tabela 4.6 - Avaliação de um SAP baseado nos critérios de habilitação para pilotos humanos: Treinamento de Voo do SAP

\begin{tabular}{|c|c|c|c|}
\hline $\begin{array}{l}\text { Requisitos para } \\
\text { concessão de licenças } \\
\text { de pilotos }\end{array}$ & $\begin{array}{l}\text { Requisitos para a } \\
\text { concessão de licença } \\
\text { para o SAP }\end{array}$ & $\begin{array}{l}\text { Resultados da } \\
\text { Inspeção do } \\
\text { Avaliador: } \\
\text { Escala Cooper } \\
\text { Harper } \\
\text { Adaptada (Figura } \\
4.5 \text { ) }\end{array}$ & $\begin{array}{l}\text { Avaliação } \\
\text { Qualitativa pelo } \\
\text { Teste de } \\
\text { Turing: SAP } \\
\text { convenceu o } \\
\text { Interlocutor? }\end{array}$ \\
\hline $\begin{array}{l}\text { Experiência em } \\
\text { treinamento } \\
\text { supervisionado com } \\
\text { simulador de voo }\end{array}$ & $\begin{array}{l}\text { Testes em ambientes } \\
\text { simulados (com injeção } \\
\text { de falhas) para } \\
\text { verificação do sistema } \\
\text { em condições } \\
\text { operacionais normais e } \\
\text { adversas. }\end{array}$ & $\begin{array}{l}\text { Não foi capaz de } \\
\text { reagir } \\
\text { adequadamente } \\
\text { diante de falhas } \\
\text { impostas. Nota } \\
\text { de Avaliação } \\
\text { Cooper Harper: } 9\end{array}$ & $\begin{array}{l}\text { Não. } \\
\text { Incompatível } \\
\text { com a } \\
\text { habilidade de } \\
\text { voo humana. }\end{array}$ \\
\hline $\begin{array}{l}\text { Instrução de voo (com } \\
\text { instrutor habilitado, em } \\
\text { duplo comando) cobrindo: }\end{array}$ & $\begin{array}{l}\text { Operação do sistema } \\
\text { em ambientes reais com } \\
\text { aumento gradual da } \\
\text { complexidade } \\
\text { (inicialmente voo } \\
\text { segregado e } \\
\text { posteriormente voo não } \\
\text { segregado em espaço } \\
\text { aéreo não controlado) e } \\
\text { com supervisão e } \\
\text { eventual atuação } \\
\text { humana remota. Essas } \\
\text { operações devem incluir } \\
\text { todos os procedimentos } \\
\text { (normais e críticos) } \\
\text { associados a todas as } \\
\text { etapas do voo (desde o } \\
\text { pré-voo até a o destino } \\
\text { final programado). } \\
\text { Considerar, no mínimo, } \\
\text { os seguintes } \\
\text { procedimentos: }\end{array}$ & $\begin{array}{l}\text { Não foi capaz de } \\
\text { interagir com as } \\
\text { alterações } \\
\text { impostas pelo } \\
\text { ATC em } \\
\text { mudanças de } \\
\text { nível de voo. Em } \\
\text { situações } \\
\text { específicas, a } \\
\text { velocidade de } \\
\text { reação foi mais } \\
\text { rápida que o } \\
\text { Controlador ATC } \\
\text { esperava, } \\
\text { desencadeando } \\
\text { situação de } \\
\text { perigo. Nota de } \\
\text { Avaliação } \\
\text { Cooper Harper: } 7\end{array}$ & $\begin{array}{l}\text { Não. } \\
\text { Incompatível } \\
\text { com a } \\
\text { habilidade de } \\
\text { voo humana. } \\
\text { Requer estudo } \\
\text { sobre o tempo } \\
\text { de reação do } \\
\text { VANT em } \\
\text { situações que o } \\
\text { Controlador ATC } \\
\text { um tempo maior } \\
\text { de reação do } \\
\text { que o } \\
\text { apresentado. }\end{array}$ \\
\hline $\begin{array}{l}\text { Procedimentos anteriores } \\
\text { ao voo (inspeções e } \\
\text { serviços no avião) }\end{array}$ & $\begin{array}{l}\text { Verificação (check-list) } \\
\text { das informações da } \\
\text { aeronave e do Plano de } \\
\text { Voo }\end{array}$ & $\begin{array}{l}\text { Checklist } \\
\text { realizado de } \\
\text { forma completa. } \\
\text { Nota de } \\
\text { Avaliação } \\
\text { Cooper Harper: } 1\end{array}$ & $\begin{array}{l}\text { Sim. Compatível } \\
\text { com a } \\
\text { habilidade de } \\
\text { voo humana. }\end{array}$ \\
\hline
\end{tabular}




\begin{tabular}{|c|c|c|c|}
\hline $\begin{array}{l}\text { Requisitos para } \\
\text { concessão de licenças } \\
\text { de pilotos }\end{array}$ & $\begin{array}{l}\text { Requisitos para a } \\
\text { concessão de licença } \\
\text { para o SAP }\end{array}$ & $\begin{array}{l}\text { Resultados da } \\
\text { Inspeção do } \\
\text { Avaliador: } \\
\text { Escala Cooper } \\
\text { Harper } \\
\text { Adaptada (Figura } \\
4.5 \text { ) }\end{array}$ & $\begin{array}{l}\text { Avaliação } \\
\text { Qualitativa pelo } \\
\text { Teste de } \\
\text { Turing: SAP } \\
\text { convenceu o } \\
\text { Interlocutor? }\end{array}$ \\
\hline $\begin{array}{l}\text { Operações em aeródromos } \\
\text { e circuitos de tráfego } \\
\text { (procedimentos para } \\
\text { prevenção de colisões) }\end{array}$ & $\begin{array}{l}\text { Operação autônoma e } \\
\text { assistida em voos } \\
\text { segregados e não } \\
\text { segregados, com } \\
\text { verificação de } \\
\text { separação mínima }\end{array}$ & $\begin{array}{l}\text { Conseguir } \\
\text { manter a } \\
\text { separação } \\
\text { mínima, porém } \\
\text { não demonstrou } \\
\text { habilidade de } \\
\text { alterações no } \\
\text { cenário } \\
\text { apresentado. } \\
\text { Nota de } \\
\text { Avaliação } \\
\text { Cooper Harper: } 6\end{array}$ & $\begin{array}{l}\text { Sim. Compatível } \\
\text { com a } \\
\text { habilidade de } \\
\text { voo humana, } \\
\text { considerando } \\
\text { um piloto } \\
\text { inesperiente. }\end{array}$ \\
\hline $\begin{array}{l}\text { Controle do avião por } \\
\text { referências externas }\end{array}$ & $\begin{array}{l}\text { Operação em ambiente } \\
\text { com informações } \\
\text { degradadas de } \\
\text { informações da } \\
\text { aeronave }\end{array}$ & $\begin{array}{l}\text { Manteve a } \\
\text { aeronave estável } \\
\text { até o momento } \\
\text { que uma } \\
\text { perturbação } \\
\text { externa foi } \\
\text { exposta. Nota de } \\
\text { Avaliação } \\
\text { Cooper Harper: } 8\end{array}$ & $\begin{array}{l}\text { Não. } \\
\text { Incompatível } \\
\text { com a } \\
\text { habilidade de } \\
\text { voo humana. }\end{array}$ \\
\hline $\begin{array}{l}\text { Voo em velocidades } \\
\text { críticas baixas } \\
\text { (reconhecimento e } \\
\text { recuperação de estol e } \\
\text { parafuso) }\end{array}$ & $\begin{array}{l}\text { Operação em } \\
\text { velocidades críticas } \\
\text { baixas (reconhecimento } \\
\text { e recuperação de estol e } \\
\text { parafuso) }\end{array}$ & $\begin{array}{l}\text { Aeronave perdeu } \\
\text { a estabilidade. } \\
\text { Nota de } \\
\text { Avaliação } \\
\text { Cooper Harper: } \\
10\end{array}$ & $\begin{array}{l}\text { Não. } \\
\text { Incompatível } \\
\text { com a } \\
\text { habilidade de } \\
\text { voo humana. }\end{array}$ \\
\hline $\begin{array}{l}\text { Voo em velocidades } \\
\text { críticas altas e saídas de } \\
\text { picadas }\end{array}$ & $\begin{array}{l}\text { Operação em } \\
\text { velocidades críticas } \\
\text { altas e saídas de } \\
\text { picadas }\end{array}$ & \begin{tabular}{|l} 
SAP não \\
detectou o limite \\
da aeronave \\
durante a razão \\
de descida. Nota \\
de Avaliação \\
Cooper Harper: \\
10
\end{tabular} & $\begin{array}{l}\text { Não. } \\
\text { Incompatível } \\
\text { com a } \\
\text { habilidade de } \\
\text { voo humana. }\end{array}$ \\
\hline $\begin{array}{l}\text { Decolagens e } \\
\text { aterrissagens normais e } \\
\text { com vento de través }\end{array}$ & $\begin{array}{l}\text { Operação de } \\
\text { decolagens e } \\
\text { aterrissagens normais e } \\
\text { com vento de través }\end{array}$ & $\begin{array}{l}\text { Pousou e } \\
\text { Decolagem com } \\
\text { vento de través } \\
\text { realizado nos } \\
\text { níveis esperados. } \\
\text { Nota de } \\
\text { Avaliação } \\
\text { Cooper Harper: } 3\end{array}$ & $\begin{array}{l}\text { Sim. Compatível } \\
\text { com a } \\
\text { habilidade de } \\
\text { voo humana. }\end{array}$ \\
\hline
\end{tabular}




\begin{tabular}{|c|c|c|c|}
\hline $\begin{array}{l}\text { Requisitos para } \\
\text { concessão de licenças } \\
\text { de pilotos }\end{array}$ & $\begin{array}{l}\text { Requisitos para a } \\
\text { concessão de licença } \\
\text { para o SAP }\end{array}$ & $\begin{array}{l}\text { Resultados da } \\
\text { Inspeção do } \\
\text { Avaliador: } \\
\text { Escala Cooper } \\
\text { Harper } \\
\text { Adaptada (Figura } \\
4.5 \text { ) }\end{array}$ & $\begin{array}{l}\text { Avaliação } \\
\text { Qualitativa pelo } \\
\text { Teste de } \\
\text { Turing: SAP } \\
\text { convenceu o } \\
\text { Interlocutor? }\end{array}$ \\
\hline $\begin{array}{l}\text { Decolagens de máximo } \\
\text { desempenho (pista curta e } \\
\text { ultrapassagem de } \\
\text { obstáculos) }\end{array}$ & $\begin{array}{l}\text { Operação de } \\
\text { decolagens de máximo } \\
\text { desempenho (pista curta } \\
\text { e ultrapassagem de } \\
\text { obstáculos) }\end{array}$ & $\begin{array}{l}\text { Realizou a tarefa } \\
\text { somente sem } \\
\text { perturbações } \\
\text { externas. Nota } \\
\text { de Avaliação } \\
\text { Cooper Harper: } 8\end{array}$ & $\begin{array}{l}\text { Não. } \\
\text { Incompatível } \\
\text { com a } \\
\text { habilidade de } \\
\text { voo humana. }\end{array}$ \\
\hline $\begin{array}{l}\text { Voo por meio de } \\
\text { instrumentos para } \\
\text { execução de curvas de } \\
\text { 180graus }\end{array}$ & $\begin{array}{l}\text { Operação de execução } \\
\text { de curvas niveladas de } \\
180 \text { graus }\end{array}$ & $\begin{array}{l}\text { Manobra } \\
\text { realizada como o } \\
\text { Esperado, } \\
\text { mesmo diante de } \\
\text { perturbações. } \\
\text { Nota de } \\
\text { Avaliação } \\
\text { Cooper Harper: } 1\end{array}$ & $\begin{array}{l}\text { Sim. Compatível } \\
\text { com a } \\
\text { habilidade de } \\
\text { voo humana. }\end{array}$ \\
\hline $\begin{array}{l}\text { Voo de navegação por } \\
\text { meio de referências } \\
\text { visuais, navegação } \\
\text { estimada e com rádio- } \\
\text { navegação }\end{array}$ & $\begin{array}{l}\text { Operação em ambiente } \\
\text { com informações } \\
\text { degradadas de } \\
\text { navegação }\end{array}$ & $\begin{array}{l}\text { Canais de } \\
\text { comunicação } \\
\text { alternativos } \\
\text { funcionaram de } \\
\text { forma } \\
\text { satisfatória. Nota } \\
\text { de Avaliação } \\
\text { Cooper Harper: } 6\end{array}$ & $\begin{array}{l}\text { Sim. Compatível } \\
\text { com a } \\
\text { habilidade de } \\
\text { voo humana. }\end{array}$ \\
\hline $\begin{array}{l}\text { Voo em situação de } \\
\text { emergência (com falhas } \\
\text { simuladas) }\end{array}$ & $\begin{array}{l}\text { Operações em } \\
\text { emergência (com falhas } \\
\text { simuladas) }\end{array}$ & $\begin{array}{l}\text { Aeronave } \\
\text { manteve-se no } \\
\text { limite da } \\
\text { estabilidade de } \\
\text { voo. Nota de } \\
\text { Avaliação } \\
\text { Cooper Harper:9 }\end{array}$ & $\begin{array}{l}\text { Não. Compatível } \\
\text { com a } \\
\text { habilidade de } \\
\text { voo humana. }\end{array}$ \\
\hline $\begin{array}{l}\text { Voo com origem, destino } \\
\text { ou trânsito por aeródromos } \\
\text { controlados }\end{array}$ & $\begin{array}{l}\text { Operações com origem, } \\
\text { destino ou trânsito por } \\
\text { aeródromos controlados }\end{array}$ & $\begin{array}{l}\text { Tarefa de } \\
\text { taxiamento } \\
\text { realizada } \\
\text { corretamente. } \\
\text { Requer testes } \\
\text { com } \\
\text { perturbações. } \\
\text { Nota de } \\
\text { Avaliação } \\
\text { Cooper Harper: } 4\end{array}$ & $\begin{array}{l}\text { Sim. Compatível } \\
\text { com a } \\
\text { habilidade de } \\
\text { voo humana. }\end{array}$ \\
\hline
\end{tabular}


Tabela 4.7 - Avaliação de um SAP baseado nos critérios de habilitação para pilotos humanos: Experiência de Voo do SAP

\begin{tabular}{|c|c|c|c|}
\hline $\begin{array}{l}\text { Requisitos para } \\
\text { concessão de } \\
\text { licenças de pilotos }\end{array}$ & $\begin{array}{l}\text { Requisitos para a } \\
\text { concessão de licença } \\
\text { para o SAP }\end{array}$ & $\begin{array}{l}\text { Resultados da } \\
\text { Inspeção do } \\
\text { Avaliador: } \\
\text { Escala Cooper } \\
\text { Harper Adaptada } \\
\text { (Figura 4.5) }\end{array}$ & $\begin{array}{l}\text { Avaliação } \\
\text { Qualitativa pelo } \\
\text { Teste de Turing: } \\
\text { SAP convenceu } \\
\text { o Interlocutor? }\end{array}$ \\
\hline $\begin{array}{l}\text { Experiência de voo } \\
\text { (incluindo uso de } \\
\text { simulador homologado, } \\
\text { voo com instrutor e voo } \\
\text { solo em mais do que } \\
\text { um aeródromo) }\end{array}$ & $\begin{array}{l}\text { Operação do sistema em } \\
\text { ambientes reais com } \\
\text { aumento gradual da } \\
\text { complexidade } \\
\text { (inicialmente voo em } \\
\text { espaço aéreo segregado } \\
\text { (área reservada), } \\
\text { passando gradativamente } \\
\text { a voos em espaço aéreo } \\
\text { não controlado e, enfim, a } \\
\text { voos em espaço aéreo } \\
\text { controlado) e sem } \\
\text { dependência de } \\
\text { supervisão ou atuação } \\
\text { humana remota em } \\
\text { condições normais. Essas } \\
\text { operações devem incluir } \\
\text { todos os procedimentos } \\
\text { (normais e críticos) } \\
\text { associados a todas as } \\
\text { etapas do voo (desde o } \\
\text { pré-voo até o destino final } \\
\text { programado). }\end{array}$ & $\begin{array}{l}\text { Conhecimento da } \\
\text { base de dados do } \\
\text { VANT mostrou-se } \\
\text { suficiente diante } \\
\text { de condições } \\
\text { adversas. Nota } \\
\text { de Avaliação } \\
\text { Cooper Harper: } 3\end{array}$ & $\begin{array}{l}\text { Sim. Compatível } \\
\text { com a habilidade } \\
\text { de voo humana. }\end{array}$ \\
\hline $\begin{array}{l}\text { Demonstrar perícia } \\
\text { (executar manobras } \\
\text { com competência: } \\
\text { manter os limites de } \\
\text { emprego do avião, } \\
\text { manobrar com } \\
\text { suavidade e precisão, } \\
\text { revelar bom julgamento } \\
\text { e aptidão, aplicar } \\
\text { conhecimentos } \\
\text { aeronáuticos e manter } \\
\text { controle da aeronave } \\
\text { durante todo o tempo } \\
\text { de voo) }\end{array}$ & $\begin{array}{l}\text { Operação do sistema em } \\
\text { ambientes reais com o } \\
\text { objetivo de verificar a } \\
\text { precisão dos algoritmos de } \\
\text { controle (executar } \\
\text { manobras conforme o } \\
\text { programado: mantendo os } \\
\text { limites da aeronave em } \\
\text { condições seguras, } \\
\text { manobrando conforme o } \\
\text { programado, controlando } \\
\text { situações de exceção } \\
\text { (falhas), utilizando as } \\
\text { informações aeronáuticos } \\
\text { e mantendo controle da } \\
\text { aeronave durante todo o } \\
\text { tempo de voo), de modo } \\
\text { igual ou superior a um } \\
\text { piloto humano. }\end{array}$ & $\begin{array}{l}\text { Para algumas } \\
\text { situações } \\
\text { expostas, o SAP } \\
\text { demonstrou } \\
\text { desempenho } \\
\text { apenas } \\
\text { satisfatório. Nota } \\
\text { de Avaliação } \\
\text { Cooper Harper: } 6\end{array}$ & $\begin{array}{l}\text { Não. Incompatíve } \\
\text { com a habilidade } \\
\text { de voo humana, } \\
\text { mesmo para } \\
\text { pilotos de } \\
\text { aeronaves de } \\
\text { pequeno porte. }\end{array}$ \\
\hline
\end{tabular}


Tabela 4.8 - Avaliação de um SAP baseado nos critérios de habilitação para pilotos humanos: Ponto de Vista do ATM Global do SAP

\begin{tabular}{|c|c|c|c|}
\hline $\begin{array}{l}\text { Requisitos para } \\
\text { concessão de } \\
\text { licenças de pilotos }\end{array}$ & $\begin{array}{l}\text { Requisitos para a } \\
\text { concessão de licença } \\
\text { para o SAP }\end{array}$ & $\begin{array}{l}\text { Resultados da } \\
\text { Inspeção do } \\
\text { Avaliador: } \\
\text { Escala Cooper } \\
\text { Harper Adaptada } \\
\text { (Figura 4.5) }\end{array}$ & $\begin{array}{l}\text { Avaliação } \\
\text { Qualitativa pelo } \\
\text { Teste de Turing: } \\
\text { SAP convenceu } \\
\text { o Interlocutor? }\end{array}$ \\
\hline $\begin{array}{l}\text { O Piloto deve ser } \\
\text { capaz de se comunicar } \\
\text { com o Controle de } \\
\text { Tráfego Aéreo }\end{array}$ & $\begin{array}{l}\text { O SAP deve ser capaz de } \\
\text { se comunicar com o } \\
\text { Controle de Tráfego } \\
\text { Aéreo }\end{array}$ & $\begin{array}{l}\text { A avaliação de } \\
\text { níveis diferentes } \\
\text { de comunicação } \\
\text { foi realizado. O } \\
\text { SAP interpretou } \\
\text { corretamente as } \\
\text { mensagens, } \\
\text { inclusive as de } \\
\text { emergências. As } \\
\text { repostas não } \\
\text { foram conforme o } \\
\text { esperado. } \\
\text { Nota de Avaliação } \\
\text { Cooper Harper: } 3\end{array}$ & $\begin{array}{l}\text { Sim. Compatível } \\
\text { com a habilidade } \\
\text { de voo humana. } \\
\text { Requer análise } \\
\text { dos dados, pois } \\
\text { algumas repostas } \\
\text { foram rápidas } \\
\text { demais para os } \\
\text { Controladores } \\
\text { ATC. }\end{array}$ \\
\hline $\begin{array}{l}\text { O Piloto deve ser } \\
\text { capaz de realizar a } \\
\text { navegação definida no } \\
\text { plano de voo e, } \\
\text { conforme demanda do } \\
\text { Controle de Tráfego } \\
\text { Aéreo, alterar o plano } \\
\text { de voo }\end{array}$ & $\begin{array}{l}\text { O SAP deve ser capaz de } \\
\text { realizar a navegação } \\
\text { definida no plano de voo } \\
\text { e, conforme demanda do } \\
\text { Controle de Tráfego } \\
\text { Aéreo, alterar o plano de } \\
\text { voo }\end{array}$ & $\begin{array}{l}\text { A Navegação foi } \\
\text { correta, com } \\
\text { exceção de } \\
\text { mudança de nível } \\
\text { diante de } \\
\text { condições } \\
\text { climáticas } \\
\text { adversas. Nota de } \\
\text { Avaliação Cooper } \\
\text { Harper: } 4\end{array}$ & $\begin{array}{l}\text { Não. Incompatível } \\
\text { com a habilidade } \\
\text { de voo humana. } \\
\text { Apesar de a } \\
\text { habilidade ter sido } \\
\text { boa, um piloto } \\
\text { humano teria } \\
\text { reagido de forma } \\
\text { mais eficiente. }\end{array}$ \\
\hline $\begin{array}{l}\text { O Piloto deve ser } \\
\text { capaz de reportar sua } \\
\text { posição para fins de } \\
\text { vigilância do Controle } \\
\text { de Tráfego Aéreo por } \\
\text { meio de equipamentos } \\
\text { necessários para voar } \\
\text { em espaço aéreo } \\
\text { controlado e não } \\
\text { segregado. }\end{array}$ & $\begin{array}{l}\text { O SAP deve ser capaz de } \\
\text { reportar sua posição para } \\
\text { fins de vigilância do } \\
\text { Controle de Tráfego } \\
\text { Aéreo por meio de } \\
\text { equipamentos } \\
\text { necessários para voar em } \\
\text { espaço aéreo controlado } \\
\text { e não segregado. }\end{array}$ & $\begin{array}{l}\text { Mesmo diante de } \\
\text { condições } \\
\text { adversas, o SAP } \\
\text { foi capaz de } \\
\text { utilizar } \\
\text { corretamente os } \\
\text { recursos da } \\
\text { aeronave VANT. } \\
\text { Nota de Avaliação } \\
\text { Cooper Harper: } 1\end{array}$ & $\begin{array}{l}\text { Sim. Compatível } \\
\text { com a habilidade } \\
\text { de voo humana. }\end{array}$ \\
\hline
\end{tabular}

Esse exemplo de aplicação de um SAP hipotético tem o objetivo de mostrar o estilo de aplicação do Safety-VANT, porém, esse método ainda necessita ser aplicado em VANT real que tenha SAP embarcado e ser projetado para atender os requisitos apresentados. Neste momento é importante considerar a forma como que estas tabelas podem ser interpretadas. Para exemplificar, o item "Conhecimentos técnicos sobre operação de aeronaves" a ser avaliado 
tem como resultado que o VANT Autônomo (SAP) foi aprovado com nota (6), mas isto não implica que o VANT foi aprovado como um todo. O fato do avaliador ter julgado desta forma, por exemplo, não necessariamente significa que esta avaliação demonstra que a capacidade de voar foi superior a de um humano, mas apenas similar ou compatível para essa determinada tarefa.

Também há a interpretação possível do avaliador considerar que, dada a precisão de ações do SAP em análise, esse tipo de condição de voo não fosse realista para ser realizado por um humano. Como resultado desta observação, parâmetros de orientação devem também ser definidos, para cada elemento, por parte do avaliador, de forma a se ter um resultado mais preciso sobre a capacidade de voo do VANT avaliado. Desta forma, a necessidade de haver uma explicação por parte do avaliador sobre suas escolhas e suas notas resulta em uma melhor qualidade dos dados fornecidos por esse avaliador. Os resultados esperados dependerão de experimentos simulados em função de avaliação subjetiva de avaliadores e também da existência de um VANT que deva atender aos parâmetros em que este será submetido ao teste. 


\section{CONCLUSÕES}

O uso de Métodos de Avaliação de Segurança Crítica é realizado por avaliadores especialistas de forma que possam, a partir de determinados parâmetros, terem a percepção sobre o quão seguro é um determinado objeto sob avaliação. $O$ ambiente e o contexto regem diversos parâmetros que podem ser mais ou menos rigorosos, mas o uso de um mesmo método em condições similares permite uma comparação de resultados e, consequentemente, uma avaliação mais precisa do objeto sob análise.

Apesar de todo o esforço feito pela comunidade científica na área de Segurança Crítica, a sensibilidade dos valores obtidos pelos métodos existentes é dependente da experiência, histórico e, inclusive confiança da comunidade que os utiliza. Uma visão aceita pela comunidade científica é a de que métodos de avaliação de segurança crítica funcionam como filtros de problemas de segurança e, dado o risco inerente de falhas não detectáveis em sistemas expostos a determinados contextos, tais filtros terão fendas passíveis de causar acidentes.

O desenvolvimento da aviação civil tripulada ocorreu com base em um histórico de muitos acidentes, realidade inaceitável para a construção do histórico da aviação não tripulada. O método Safety-VANT, desenvolvido nesta Tese, representa uma importante ferramenta, sendo um método dedicado com foco na avaliação do Sistema Autônomo de Pilotagem do VANT, algo não abordado em uma longa lista de métodos existentes, conforme apresentado no capítulo 3. Da mesma forma que ocorre com os demais métodos, não há como garantir a completeza do Safety-VANT sem a construção de um histórico acumulado, preferencialmente, em ambientes controlados. A avaliação de VANT permitirá construir um histórico e referências para futuros avaliadores especialistas quando forem avaliar VANT similares.

O VANT definido nesta Tese, ou seja, o VANT com o Sistema Autônomo de Pilotagem embarcado suscita um vasto espectro de problemas a serem resolvidos e que não existem na aviação civil tripulada. O Safety-VANT foi desenvolvido de forma genérica para ser usado para cada problema e situação apresentada por especialistas e projetistas de veículos aéreos não tripulados, 
sem depender de alteração no método em si. A partir do uso do Safety-VANT em diferentes cenários e situações, inicia-se, então, a construção de uma base de dados de referência comum aos interessados e envolvidos. A partir de referências pré-existentes, o refino das exigências mínimas definidas pelas autoridades aeronáuticas poderá ser feito continuamente, diminuindo ou aumentando o rigor de parâmetros sem que vidas humanas sejam comprometidas no processo. Esse refino pode ser feito pela alteração dos Requisitos Gerais de Segurança, utilizados no Safety-VANT.

Desta forma, será possível utilizar tal base de dados para a certificação de futuros VANT, definindo requisitos mínimos de segurança crítica, sem a necessidade de entender a tecnologia específica que estiver sendo utilizada. $O$ uso deste método torna possível a adoção de uma padronização na avaliação da segurança crítica de VANT comerciais por parte dos órgãos reguladores e certificadores.

Esta Tese teve seu cenário estabelecido no Espaço Aéreo Controlado e Não Segregado, tendo como foco a avaliação do SAP contido no VANT. A escolha deste contexto permitiu desenvolver o método considerando as condições mais rigorosas exigidas pelo gerenciamento de tráfego aéreo internacional.

\subsection{Contribuições}

A principal contribuição desta Tese está no desenvolvimento do método SafetyVANT, o qual se utiliza de princípios da aviação civil definidos internacionalmente. A conversão desses princípios da aviação civil foi feita por meio do uso da Metodologia de Avaliação de Segurança da Eurocontrol que resultou nos Requisitos Gerais de Segurança adaptados ao Sistema Autônomo de Pilotagem (SAP) do VANT. Para oferecer uma forma de quantificar o uso destes requisitos em uma avaliação do SAP, utilizou-se uma escala de Cooper Harper modificada, e, para parâmetros de referência do SAP em relação aos pilotos humanos, realiza-se um teste, por parte do avaliador, por meio do Teste de Turing.

Um aspecto importante a ser ressaltado é que foi proposta uma separação entre o Sistema Autônomo de Pilotagem e a aeronave. Esta separação é 
comparável, à aviação civil, no qual o processo de certificação de aeronaves independe do piloto a bordo (seja autônomo ou humano).

Pode-se dizer que o método aqui proposto colabora para o desenvolvimento de uma base científica que possibilite 0 suporte à regulamentação para a operação segura dos VANT perante a sociedade.

Os questionamentos apresentados por meio do Safety-VANT oferecem a possibilidade de classificar com maior precisão um VANT sob avaliação, pois, atualmente, a única forma de classificação feita pelos órgãos reguladores está baseada em características físicas, como tamanho e peso. Nesse tipo de classificação não há uma análise de risco associada.

O desenvolvimento dos Requisitos Gerais de Segurança oferece uma forma de padronização entre avaliadores para determinar sob quais critérios que o VANT deve ser avaliado. Consequentemente, ao se usar requisitos comuns, torna-se possível a comparação dos resultados com o resultado de outros avaliadores, aumentando a cobertura dessa avaliação.

O fato dos requisitos terem sido desenvolvidos tendo como base as ações executadas por um piloto humano pode levar a conclusões de que o SAP tem um desempenho melhor do que o ser humano, ou, pelo contrário, não consegue substituir o ser humano no controle de uma aeronave.

Outra contribuição desta Tese está no desenvolvimento da Escala Cooper Harper Modificada, constituindo-se em uma importante ferramenta na avaliação do VANT. Além disso, o Teste de Turing para VANT permite também identificar os pontos necessários de imediata melhoria por parte dos desenvolvedores para os casos em que o VANT não tenha tido um desempenho igual ao de um piloto humano. Mesmo em posse dos resultados que o Safety-VANT propiciam, a certificação final de um VANT sempre estará a cargo de um órgão certificador que normalmente conta com vários especialistas para coletar os dados de avaliação para a tomada de decisão. De forma resumida, se for provado que há uma única situação insegura na avaliação de um VANT, caberá ao seu desenvolvedor provar que a situação tenha sido sanada. 
Finalmente, outra contribuição desta Tese para o domínio de avaliação do VANT foi a taxonomia apresentada no capítulo 2, de forma a se evitar a avaliação do SAP pelos mesmos critérios que se avaliaria o hardware e software que o compõe.

Desta forma, o Safety-VANT foi desenvolvido para quantificar a qualidade de um Sistema Autônomo de Pilotagem controlando uma aeronave, etapa fundamental para o processo de certificação desse SAP. Contando com processos quantificáveis, tal como o método apresentado, é possível visualizar a integração de VANT no espaço aéreo, desde que atenda aos mesmos limites de segurança aplicados à aviação civil atual.

\subsection{Trabalhos Futuros}

Durante o desenvolvimento desta Tese, foram verificadas algumas possibilidades relevantes de estudos futuros decorrentes deste trabalho:

1) Ampliação do escopo do Safety-VANT nas seguintes condições:

a. Desenvolvimento de um VANT "ideal" para referência dos avaliadores. Esse VANT seria considerado Autônomo e atenderia a todas as condições necessárias e suficientes para voar de forma segura no espaço aéreo controlado e não segregado. Em particular, para o desenvolvimento de uma pesquisa do VANT "ideal" seria necessário o refino das notas que os avaliadores dariam aos VANT reais;

b. Possibilidade de Expansão do método: um desafio para os órgãos reguladores no uso de metodologias de avaliação de segurança baseadas em especialistas é evitar ambiguidades na definição e uso de requisitos. Tais ambiguidades podem gerar resultados imprecisos no uso da escala. Isso pode resultar em classificações diferentes de um avaliador para outro mesmo para um mesmo SAP sob avaliação de um mesmo requisito. Há a necessidade de desenvolvimento de pesquisas relacionadas à qualidade de dados gerada por avaliadores assim como processos de verificação de habilidades dos avaliadores. 
c. Desenvolvimento da Base de Dados de Avaliações Realizadas: a ausência de VANT com as características necessárias para aplicar o Safety-VANT inviabilizaram o desenvolvimento da base de dados de avaliações que permitiriam fornecer informações a avaliadores especialistas assim como a própria realimentação para refino do método Safety-VANT. Há, portanto a necessidade de aplicar o método em VANT que venha a ser desenvolvido para que diferentes avaliadores forneçam dados para a geração dessa base.

d. Desenvolvimento de Requisitos Específicos de Segurança: O SAP necessita ser certificado tanto pelo tipo da aeronave (responsabilidade da ANAC) quanto pelo seu comportamento no espaço aéreo (responsabilidade do DECEA). O Requisito Geral de Segurança do SAP foi desenvolvido pela premissa de o VANT ser capaz de voar de forma segura sem interferir no Controle de Tráfego Aéreo. Esse requisito pode ser dividido em Requisitos Específicos, visando a melhor forma de atender as demandas específicas.

2) Desenvolvimento da Função Viabilidade, proposta no capítulo 4: a Função Viabilidade é uma possibilidade de ampliação do processo de certificação de um VANT, considerando outros elementos além da variável Segurança Crítica abordada na Tese. Seu desenvolvimento poderia colaborar com os órgãos responsáveis para o desenvolvimento do conceito aeronáutico chamado de Lista Mínima de Equipamentos (Minimal Equipment List - MEL). A MEL de um SAP embarcado em um VANT ainda é material de estudo que pode orientar os desenvolvedores a seguirem uma linha pré-definida.

3) Desenvolvimento de Ambientes de Simulações para o Safety-VANT:

Uma etapa utilizada na avaliação e teste de sistemas críticos é o uso de simuladores. O Avaliador procura garantir, antes de voos reais, que haja pouca ou nenhuma diferença entre as simulações realizadas e o teste de voo real (CUMMINGS, MYERS, SCOTT, 2008; DONMEZ, 2008). As únicas diferenças comumente aceitas são tipos de situações difíceis de serem simuladas por não se ter o ambiente de movimento completo de 
uma nova aeronave, mesmo com sofisticados simuladores de voo e de controle de tráfego aéreo. Do ponto de vista do gerenciamento do tráfego aéreo, um SAP deve ser certificado em cenários de operação. A avaliação desses cenários deve considerar as regras de navegação aérea civil, todas as possíveis interfaces com as outras aeronaves do espaço aéreo considerado, bem como todos os cenários de operação (normal e degradada) possíveis. O enfoque desses cenários deve ser de aumento gradativo de complexidade, permitindo o teste do sistema em diversas etapas (podendo haver níveis de complexidade específicos para o ambiente do SAP, como por exemplo: voo em região restrita, voo em região não condicionada e de baixa densidade de tráfego, voo em região não condicionada de alta densidade de tráfego, etc.). Como existe a necessidade de interação entre o SAP e o ambiente de simulação ATM, é necessário que o ambiente de simulação tenha interfaces compatíveis com o sistema de navegação autônoma. Do ponto de vista da certificação de um SAP em um ambiente real de tráfego aéreo controlado, considera-se necessário que sejam realizados voos de teste supervisionados por um elemento humano qualificado ou por outro equipamento já também já qualificado.

4) Desenvolvimento de um Conjunto Padrão de Testes pelo Método SafetyVANT: depende de um histórico de dados que devem ser acumulados e expostos possibilitando o desenvolvimento de procedimentos de testes padronizados para realizá-los.

5) Sistema de Controle de Tráfego Aéreo Autônomo: VANT com ATC Autônomo: seria um sistema totalmente autônomo, dependendo de uma grande rede de computadores distribuída por todo o território internacional onde há voos controlados. 


\subsection{Considerações Finais}

O desenvolvimento do método Safety-VANT foi realizado por um processo de desenvolvimento de pesquisa que envolveu diversas interações com os interessados e envolvidos na ampliação do VANT no Espaço Aéreo. O método desenvolvido mostrou-se como o início de uma jornada científica para a validação da segurança crítica de VANT compartilhando o espaço aéreo com aeronaves tripuladas, mas, por ser um método dedicado, o objetivo desta pesquisa foi cumprido dentro das condições de contorno definidas. Portanto, o desenvolvimento e a ampliação desse método devem ser continuados em prol de um sistema de tráfego aéreo mais seguro e preparado para a inserção de novas tecnologias e abordagens tais como o VANT Autônomo integrado ao Espaço Aéreo Controlado e Não Segregado. 


\section{REFERÊNCIAS}

ALLOUCHE, M. The Integration of UAVs in Airspace. Air \& Space Europe, vol. 2, no. 1. pp. 101-104, 2000. DOl 10.1016/S1290-0958(00)80019-2.

ALMEIDA JR, J.R. de. Segurança em sistemas críticos e em sistemas de Informação: um estudo comparativo. Tese (Livre-Docência) - Escola Politécnica, Universidade de São Paulo. São Paulo. 2003. 191 p.

ANAC. Regulamento Brasileiro da Aviação Civil No. 01. Definições, Regras de Redação e Unidades de Medida para Uso nos RBAC. Diário Oficial da União. 2011a. 22 p.

ANAC. Regulamento Brasileiro da Aviação Civil No. 21-01. Certificação de Produto Aeronáutico. Diário Oficial da Unnião. 2011b. 70 p.

ANAC. Regulamento Brasileiro De Homologação Aeronáutica 141. Escolas de Aviação Civil. Portaria № 827/DGAC. Diário Oficial da União. 2004. 42p.

ANAC. Regulamento Brasileiro da Aviação Civil No. 61. Licenças, Habilitações e Certificados Para Pilotos. Diário Oficial da União. 2012a. 89 p.

ANAC. Emissão de Certificado de Autorização de Voo Experimental para Veículos Aéreos Não Tripulados. INSTRUÇÃO SUPLEMENTAR - IS IS № 21-002 Revisão A. Diário Oficial da União. 2012b. 21 p.

ASTM. F2501-06, Standard Practices for Unmanned Aircraft System Airworthiness (Withdrawn 2015), ASTM International, West Conshohocken, PA, 2006. Disponível em: www.astm.org. Último acesso: 18 Abr. 2015.

AUSTIN, Reg. Unmanned Aircraft Systems. Primeira Edição. Ed. Wiley. 2010. 332 p.

AVANZINI, G., MINISCI, E.A. Evolutionary Design of a Full-envelope Flight Control System for an Unstable Fighter Aircraft. In: 2010 IEEE Congress on Evolutionary Computation (CEC), pp. 1-8. 2010.

BAILEY, Randall E. Cooper Harper Experience Report for Spacecraft Handling Qualities Applications. NASA/TM-2009-215767 NASA. Langley Research Center, Hampton, Virginia. 2009. Disponível em: <http://ntrs.nasa.gov/search.jsp?R=20090025299>. Acesso em: 18 Abr. 2015.

CELIK, Sirma. Safety process implementation for Unmanned Aerial Systems. Achieving Systems Safety - Proceedings of the 20th Safety-Critical Systems Symposium, SSS 2012, 2012, pp. 43-53. 
CIVILIAN Applications: the Challenges Facing the UAV Industry. Uninhabited Aerial Vehicles (UAVs). Air \& Space Europe. Vol. I. No. 5-6. p. 63-66. 1999. DOI 10.1016/S1290-0958(00)88873-5.

CLOTHIER, R., et al.: A casualty risk analysis for unmanned aerial system (UAS) operations over inhabited areas. In: 2nd Australasian Unmanned Air Vehicles Conference. 2007.

COMPUTAÇÃO BRASIL. Veículos Autônomos Não Tripulados. Volume 1. 2014. Disponível em: <http://sbc.org.br/cb/cb012014.pdf>. Acesso em: 18 Abr. 2015.

COHEN, Irun R.; SEGEL, Lee A. Design Principles for the Immune System and Other Distributed Autonomous Systems. Santa Fe Institute Studies in the Sciences of Complexity Proceedings. Oxford University Press. USA. 2001. $428 \mathrm{p}$.

COOPER, G. E. Understanding and interpreting pilot opinion. Aeronautics Engineering Review, Vol. 16, No. 3, 47-51. 1957.

COOPER, G. E., and HARPER, Jr., R.P. The Use of Pilot Rating in the Evaluation of Aircraft Handling Qualities. NASA TN D-5153, 1969.

CORREA et. Al. Safety Concerns on Operating UAV Using Cooperative Multiagent Negotiation. In: MVS 2006 - First IFAC Workshop on Multivehicle Systems, 2006, Salvador. First IFAC Workshop on Multivehicle Systems, 2006. v. 1. p. $102-107$

COTTING, M. C. UAV Performance Rating Scale Based on the Cooper Harper Piloted Rating Scale in 49th AIAA Aerospace Sciences Meeting including the New Horizons Forum and Aerospace Exposition, 2011. DOI:10.2514/6.2011-923.

CUMMINGS, M. L., MYERS, K., \& SCOTT, S. D. Modified Cooper Harper evaluation tool for unmanned vehicle displays Proceedings of UVS. Conference on Unmanned Vehicle Systems Canada. Montebello, PQ, Canada. 2008.

DALAMAGKIDIS, K.; VALAVANIS. , K.; PIEGL, L. On integrating unmanned aircraft systems into the national airspace system. Dordrecht: Springer Netherlands, 2012.

DECEA. Veículos Aéreos Não Tripulados. AIC N 21/10. 2010. Disponível em: <http://goo.gl/uiAsna>. Acesso em: 18 Abr. 2015. 7 p.

DECEA. DCA 351-2. Concepção Operacional ATM Nacional. Departamento de Controle do Espaço Aéreo. Ministério da Defesa. 2011. 93 p. Disponível em <http://publicacoes.decea.gov.br>. Acesso em: 18 Abr. 2015.

DECEA. Aeronave Remotamente Pilotada é tema de evento internacional promovido pelo DECEA. 2012. Disponível em: 
$<$ http://www.decea.gov.br/decea-recebe-especialistas-em-evento-internacionalsobre-aeronaves-remotamente-pilotadas/>. Acesso em: 18 Abr. 2015.

DECEA. Abreviaturas. Serviço de Informação Aérea. Disponível em <http://www.aisweb.aer.mil.br/?i=abreviaturas>. Acesso em: 18 Abr. 2015.

DONMEZ, Birsen et al. Modified Cooper Harper Scales for Assessing Unmanned Vehicle Displays. Massachusetts Institute Of Technology. 2008. Disponível em: <http://web.mit.edu/aeroastro/labs/halab/papers/MCHUVD.pdf>. Acesso em: 18 Abr. 2015.

DOSSIER. Civilian Applications: the Challenges Facing the UAV Industry. Uninhabited Aerial Vehicles (UAVs). Air \& Space Europe. Vol. I. No. 5/6. 1999

EASA. Regulamento (CE) N. o 216/2008 do Parlamento Europeu e do Conselho Relativo a Regras Comuns no Domínio da Aviação Civil e que cria a Agência Europeia para a Segurança da Aviação, e que revoga a Directiva 91/670/CEE do Conselho, o Regulamento (CE) n. o 1592/2002 e a Directiva 2004/36/CE. 2008. Disponível em: $<$ https://easa.europa.eu/unmanned-aircraft-systems-uas-and-remotely-pilotedaircraft-systems-rpas>. Acesso em: 18 Abr. 2015.

\section{EUROCONTROL. SAM V2.1 - Air Navigation System Safety Assessment Methodology. SAF.ET1.ST03.1000-MAN-01. European Air Traffic Management. 2006a. Disponível em: $<$ https://www.eurocontrol.int/articles/safety-assessment-methodology-sam>. Acesso em: 18 Abr. 2015.}

EUROCONTROL. FHA V2-0 - Safety Objectives Specification. SAF.ET1.ST03.1000-MAN-01-01-03. European Air Traffic Management. 2006b. Disponível em: <https://www.eurocontrol.int/articles/safety-assessmentmethodology-sam>. Acesso em: 18 Abr. 2015.

EUROCONTROL. PSSA V2-1 - Preliminary System Safety Assessment . SAF.ET1.ST03.1000-MAN-01-02-00. European Air Traffic Management. 2006c. Disponível em: <https://www.eurocontrol.int/articles/safety-assessmentmethodology-sam>. Acesso em: 18 Abr. 2015.

EUROCONTROL. SSA V1-1 - System Safety Assessment. SAF.ET1.ST03.1000-MAN-01-03-00. European Air Traffic Management. 2006d. Disponível em: <https://www.eurocontrol.int/articles/safety-assessmentmethodology-sam>. Acesso em: 18 Abr. 2015.

EUROCONTROL. ESARR - Safety Regulatory Requirement, Safety Oversight In ATM, Version 2.0, 2009.

EUROCONTROL. SPEC - 0102 Specifications for the use of Military Unmanned Aerial Vehicles as Operational Air Traffic Outside Segregated Airspace, 2012. Disponível em www.eurocontrol.int. Acessado em 18 Abr. 2015. 
EUROCONTROL. Roadmap for the integration of civil RPAS into the European Aviation System. Anexo 2. 2013. 16 p. Disponível em: <http://ec.europa.eu/enterprise/sectors/aerospace/uas/index_en.htm>. Acesso em: 18 Abr. 2015.

EVERDIJ, M. H.C.; BLOM, H. A. P. Safety Methods Database. Version 1.0. Maintained by NLR. 2013. Disponível em: <http://www.nlr.nl/downloads/safetymethods-database.pdf>. Acesso em: 18 Abr. 2015.

FAA. Small UAS Notice of Proposed Rulemaking (NPRM). Disponível em: <https://www.faa.gov/uas/nprm/>. Acesso em: 18 Abr. 2015.

GAIN. Guide to Methods \& Tools for Safety Analysis in Air Traffic Management. Primeira Edição. 2003. Disponível em: $<$ http://flightsafety.org/files/methods_tools_safety_analysis.pdf>. Acesso em: 18 Abr. 2015.

GIL, A. C. Métodos e técnicas de pesquisa social. São Paulo: Atlas. 1999.

GIL, F.O. et. al. PIpE-SEC: Platform for Tests and Validation of Unmanned Aerial Vehicles (UAVs) Operation in Controlled Airspace. Journal of the Brazilian Air Transportation Research Society, v. 6, p. 47-60, 2010.

GIMENES, R.V.G.; ALMEIDA JR, J. R. . Uncertanty Decision Making in Unmanned Aerial Vehicles. In: Second International Conference on Research in Air Transportation, 2006, Belgrado. Proceedings of Second International Conference on Research in Air Transportation. Belgrado: DS Public, 2006. v. 1. p. 441-444.

GIMENES, R. A. V. et al. Simulation Meets Reality: A Cooperative Approach to RoboCup's Physical Visualization Soccer League. In: EPIA 200713 th Portuguese Conference in Artificial Intelligence, 2007, Guimarães. Progress in Artificial Intelligence - Proceedings of the 13th Portuguese Conference on Artificial Intelligence, 2007. v. 1. p. 1-12.

GIMENES, R. A. V. ; ALMEIDA, J. R. Taxonomies Related to Unmanned Vehicles for Civilian Applications. In: ESREL 2007 - European Safety and Reliability Conference, 2007, Stavanger. Taxonomies Related to Unmanned Vehicles for Civilian Applications. London: Taylor \& Francis/Balkema, 2007. v. 3. p. 2107-2111.

GIMENES, R.V.G.; ALMEIDA JR, J. R. . Human Factors Associated with UAV in a Non-Segregated Air Navigation System. In: 15th Air Traffic Research Society, 2011, Sydney. Proceedings of 15th Air Traffic Research Society, 2011. v. 1. p. 1-14.

GIMENES, R.V.G. et al. Proposta de Taxonomia para VANTs. In: XI SITRAER - Simpósio Brasileiro de Pesquisa em Transporte Aéreo, 2012, Brasília. Anais do XI SITRAER - Simpósio Brasileiro de Pesquisa em Transporte Aéreo, 2012. v. 1. p. 23-28. 
GIMENES, R.V.G. et al;. Guidelines for Integration of Autonomous UAS in Global ATM. The 2013 International conference on Unmanned Aircraft Systems, ICUAS'13. Atlanta. 2013.

GIMENES, R.V.G. et al. Guidelines for the Integration of Autonomous UAS into the Global ATM. Journal of Intelligent \& Robotic Systems. 74, 465-478. 2014. DOI 10.1007/s10846-013-9945-0.

GUPTA, Suraj G.; GHONGE, Mangesh M.; JAWANDHIYA, P. M. Review of Unmanned Aircraft System (UAS). International Journal of Advanced Research in Computer Engineering \& Technology (IJARCET) Volume 2, Issue 4. p. 1646-1658 ISSN: 2278-1323. 2013.

HARPER, R. P., Jr.; COOPER, G. E. Handling Qualities and Pilot Evaluation Journal of Guidance, Control, and Dynamics, Vol. 9. No. 5. pp. 515-529. 1986.

HARRIS, D., CHAN-PENSLEY, J., and MCGARRY, S., The Development of a Multidimensional Scale to Evaluate Motor Vehicle Dynamic Qualities Ergonomics, Vol. 48, No. 5, June 2005, pp. 964-982.

HODGKINSON, J., POTSDAM, E.H., SMITH, R.E. Interpreting The Handling Qualities Of Aircraft With Stability And Control Augmentation. AIAA Atmospheric Flight Mechanics Conference, No. AIAA-1990-2825, Portland, OR. 1990.

ICAO. Chicago Convention. Doc 7300, 1944.

ICAO. Annex 2 to the Convention on International Civil Aviation - Rules of the Air - International Civil Aviation Organization. Ninth Edition. 1990.

ICAO. Annex 10 to the Convention on International Civil Aviation - Radio Navigation Aids. Fifth Edition. 1996.

ICAO. Annex 17 to the Convention on International Civil Aviation Security Safeguarding International Civil Aviation Against Acts of Unlawful Interference. Sixth Edition. 1997.

ICAO. Annex 1 to the Convention on International Civil Aviation Personnel Licensing - International Civil Aviation Organization. Ninth Edition. 2001a.

ICAO. Annex 6 to the Convention on International Civil Aviation Operation of Aircraft. Eighth Edition. 2001b.

ICAO. Annex 8 to the Convention on International Civil Aviation Airworthiness of Aircraft. Ninth Edition. 2001c.

ICAO. Global Air Traffic Management Operational Concept. Ed 1. Doc 9854. 2004. 
ICAO. Unmanned Aircraft Systems (UAS) Circular. UAS 328, Cir.328 AN/190. 2011. ISBN: 978-92-9231-751-5.

ICAO. Global Air Navigation Plan 2013-2028. Document 9750. Quarta Edição. 2013. 128 p. Disponível em: <www.icao.int/publications/>. Acesso em: 18 Abr. 2015.

ICUAS. International Conference on Unmanned Aircraft Systems. Final Program and Book of Abstracts. 2013.

IEC 61508. Functional safety of electrical/electronic/programmable electronic safety related systems. First Edition. 1998. $471 \mathrm{p}$.

JAA. UAV Task-Force Final Report. The Joint JAA/Eurocontrol Iniciative on UAVs A Concept for European Regulations for Civil Unmanned Aerial Vehicles (UAVs). 2004. Disponível em:

<http://www.easa.europa.eu/system/files/dfu/NPA_16_2005_Appendix.pdf>. Acesso em: 18 Abr. 2015.

KUO, B.C. Automatic Control Systems, 5th edn. Prentice-Hall, Inc., Upper Saddle River. 1987.

LAKATOS, E. M.; MARCONI, M. de A. Fundamentos de Metodologia Científica. São Paulo: Atlas, 1993.

LAX, M.; SUTHERLAND, B. An Extended Role for Unmanned Aerial Vehicles in the Royal Australian Air Force. Air Power Studies Centre Paper Number 46. 1996. 11 p.

LOH, R.; BIAN, Y.; ROE, T. UAVs in Civil Airspace: Safety requirements. IEEE Aerospace and Electronic Systems Magazine, vol. 24, no. 1. 2009. pp. 517. DOI: 10.1109/MAES.2009.4772749.

MALPICA, C. et al. Handling Qualities of Large Rotorcraft in Hover and Low Speed. National Aeronautics and Space Administration (NASA). 2015. Disponível em: <http://halfdome.arc.nasa.gov/Publications/files/Malpica_TP2015-216656.pdf>. Acesso em: 18 Abr. 2015.

MITCHELL, D. G. et al. Evolution, Revolution, and Challenges of Handling Qualities. Journal of Guidance, Navigation, Control, and Dynamics, Vol. 27, No. 1, 2004, pp. 12-28.

NEUMANN, F.; REICHENBERGER, A.; ZIEGLER, M. Variations of the turing test in the age of internet and virtual reality. Proceedings of the 32nd annual German conference on Advances in artificial intelligence, 2009, pp. 355-362.

OLIVEIRA, Í. de ; GIMENES, R. A. V.; ALMEIDA JR, J. R. . Component-Based Development of Aeronautical Software. In: Li Weigang; Alexandre de Barros; Italo Romani de Oliveira. (Org.). Computational Models, Software Engineering, and Advanced Technologies in Air Transportation: Next Generation 
Applications. 1ed.Hershey: Engineering Science Reference, 2009, v. 1, p. 287314.

OLIVEIRA, S. L. DE. Tratado de metodologia científica: projetos de pesquisa, TGI, TCC, monografias, dissertações e teses. São Paulo: Pioneira Thomson Learning, 2012.

PAHSA, A. et al. Integrating navigation and surveillance of Unmanned Air Vehicles into the civilian national airspaces by using ADS-B applications. in Integrated Communications, Navigation and Surveilance Conference (ICNS). 2011, pp. J7-1 -J7-7.

RTCA / EUROCAE. Software Considerations in Airborne Systems and Equipment Certification. DO-178C/ED-12C. 2011.

THOMPSON, H. A. Wireless Sensor Research at yhe Rolls-Royce Control and Systems University Technology Centre. Proceedings of the 2009 1st International Conference on Wireless Communication, Vehicular Technology, Information Theory and Aerospace and Electronic Systems Technology. Wireless VITAE 2009. pp. 571-576. DOl: 10.1109/WIRELESSVITAE.2009.5172509

SABATINI, N. A. Testimony, Federal Aviation Administration, March 29, 2006.

SAE . Aerospace Recommended Practice (ARP) - Guidelines For Development Of Civil Aircraft and Systems. ARP4754. 2010. Disponível em: <http://www.sae.org/technical/standards/arp4754a>. Acesso em: 18 Abr. 2015.

SAYGIN, A. Pinar et al. Turing Test: 50 Years Later Minds and Machines, vol. 10, no. 4, pp. 463-518, 2000.

SCHIFF, B., Flying Wisdom - The Proficient Pilot. Volume 3. Golden Press. 1997. 342 p.

SCHIFF, B., The Proficient Pilot. Volume 2. Golden Press. 2001a. 324 p.

SCHIFF, B., Test Pilot. Golden Press. 2001b. 388 p.

SCHIFF, B., The Proficient Pilot. Volume 1. Golden Press. 2003. 324 p.

SILVA, E. L. da; MENEZES, E. M. Metodologia da Pesquisa e Elaboração de Dissertação. Florianópolis. 4a. Edição. UFSC. 2005.

SPITZER, C. R. Digital Avionics Handbook (Development and Implementation Electrical Engineering Handbook), Second Ed. Boca Raton, Florida, USA: CRC Press, 2007. ISBN 0-8493-8441-9. 
STOKER, Joanne; SIMPSON, Alan. Safety Assurance Report on Draft Eurocontrol Specifications for Military UAV as OAT Outside Segregated Airspace. Functional Hazard Assessment/Preliminary System Safety Assessment Report for Military UAV as OAT Outside Segregated Airspace. Eurocontrol. 2005. 145 p.

STRONG, M., UAS Market Assessment, EUROCONTROL UAS ATM Integration Workshop, EUROCONTROL, Europe. 2008.

SULLIVAN, J. M. Revolution or Evolution? The Rise of the UAVs. IEEE ISBN: 0-7803-9284-1/05. 2005.

TAN, W et al. A method for predicting aircraft flying qualities using neural networks pilot model in The 2014 2nd International Conference on Systems and Informatics (ICSAI 2014), 2014, pp. 258-263.

TURING, Alan Computing Machinery and Intelligence. Mind, Vol. 59(236), pp. 433-460, 1950.

UASSG. Unmanned Aircraft Systems Study Group. Tenth ICAO Meeting. Command and Control (C2) link provision, link certification and requirement for Annex 10 SARPs (brainstorming). 2012.

WHITLOCK, Craig. When drones fall from the sky. The Washington Post. Publicado em 20 de Jun. 2014. Disponível em: $<$ http://www. washingtonpost.com/st/investigative/2014/06/20/when-drones-fallfrom-the-sky/>. Acesso em: 18 Abr. 2015.

WILSON, D. J. and RILEY, D. R., Cooper Harper Pilot Rating Variability Atmospheric Flight Mechanics Conference, No. AIAA-89-3358, AIAA, Boston, MA, August 14-16 1989, pp. 96-105.

YIN, R. K. Estudo de Caso - Planejamento e Métodos. 4th ed. 2010. 